September, 1943

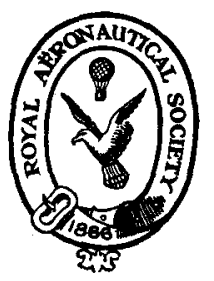

\title{
Abstracts from the Scientific and Technical Press
}

(No. 114. July, 1943)

AND

Titles and References of Articles and Papers Selected from Publications (Reviewed by R.T.P.3)

TOGETHER WITH

List of Selected Translations

(No. 60)

London :

"THE ROYAL AERONAUTICAL SOCIETY"

with which is incorporated "The Institution of Aeronautical Engineers"

4, Hamilton Place, W.1

Telephone: Grosvenor 3515 (3 lines) 


\title{
ABSTRACTS FROM THE SCIENTIFIC AND TECHNICAL PRESS.
}

\author{
Issued by the \\ Directorates of Scientific Research and Technical Development, Air Ministry
}

(Prepared by R.T.P.3.)

No. 114. JuLY, 1943.

Notices and abstracts from the Scientific and Technical Press are prepared primarily for the information of Scientific and Technical Staffs. Particular attention is paid to the work carried out in foreign countries, on the assumption that the more accessible British work (for example that published by the Aeronautical Research Committee) is already known to these Stafts.

Requests from scientific and technical staffs for further information of translations should be addressed to R.T.P.3, Ministry of Aircraft Production, and nor to the Royal Aeronautical Society.

Only a limited number of the articles quoted from foreign journals are translated and usually only the original can be supplied on loan. If, however, translation is required, application should be made in writing to R.T.P.3, the requests being considered in accordance with existing facilities.

Note.-As far as possible, the country of origin quoted in the items refers to the original source.

A Note on the Effect of Wind Tunnel Size on Pitching Moments. (Th. Troller, Kármán Anniversary Vol. of App. Mechanics, I941, pp. 231-236.) (114/1 U.S.A.)

The main conclusions are:-

1. The effect of the wind tunnel dimensions on the pitching moment of large streamlined bodies can be of such magnitude as to impair seriously the value of such tests. An analytical method of finding correction factors is not available and appears difficult to obtain.

2. For pitching moment effects on wings spanning the whole stream a simple correction method can be given.

According to the existing aerodynamic theory on wind tunnel effects, there should be an additional curvature of the air stream existing at the position of the wing, caused by the restraining action of the dimensions of the finite air stream. The curvature is of such direction as to increase slightly the lift at a given angle of attack of the wing in a closed tunnel and to decrease the lift in an open air stream. We may assume that the corrective lift force acts at the halfchord point of the aerofoil and therefore has a moment about the quarter-chord point equal to $\Delta L c / 4$.

Test results for the three different conditions are given, and it is assumed that the tests in the variable-density tunnel of the N.A.C.A., due to the small dimension of the model relative to the tunnel diameter, require no wind tunnel 
correction on pitching moment. There is also given a theoretical curve for model and wind tunnel dimensions corresponding to the tests reported. This theoretical curve is obtained by assuming that a corrective pitching moment is due to $\Delta c_{\mathbf{L}}$ values as given below for various ratios of the chord to the closed wind tunnel cross section, $c=$ wing chord, $k=$ cross section of air stream.
$c / k$
O.I
0.2
0.043
0.3
0.063
0.4
0.083
0.5
0.100

The corrective pitching moment coefficient is assumed to be equal to $\Delta c_{\mathrm{m}}=-\Delta c_{\mathrm{L}} / 4$. The value $\Delta c_{\mathrm{m}}$ deduced from the curve for the test results in the variable-density tunnel gives the line marked "theoretical."

On applying the results reasonable agreement is obtained. Further refinements of the method are possible. For instance, by substituting for one bound vortex at the quarter-chord point of the wing two or more vortices distributed in a simple manner along the chord it might be possible to obtain better approximations for the wind tunnel correction of still larger wings in a not too complicated manner.

Condenser Scoop Design. (E. F. Hewins and J. R. Reilly, Society of Naval Architects and Marine Engineers. Transactions, Vol. 48, 1940, pp. 277304.) (I $14 / 2$ U.S.A.)

It is common practice in the case of high speed steam ships to obtain the necessary cooling water for the condenser by connecting a branch circuit to two holes in the ship's bottom.

The holes may be either at the same distance from the bow but displaced laterally, thus giving rise to an athwartship installation for the condensers, or the holes may be at different longitudinal distances. In either case the object is to produce the maximum possible dynamic head at entry combined with as great a suction head as possible at delivery. For this purpose the entry hole (usually of rectangular section) is connected to a lead-in pipe set at an angle of about 35 degrees with the ship's bottom and sloping towards the rear. This so-called inlet scoop does not project outside the hull. The outlet scoop on the other hand consists of a circular pipe placed at right angles to the hull and provided with a lip on its forward wall which projects into the water.

The author investigates this problem experimentally using an $8 \times 8$ in. channel passing about 3,000 gallons/minute.

The condenser circuit consisted of 2 in. circular piping with an outlet scoop of the same diameter whilst the rectangular section of the inlet scoop could be varied. This section is flared so as to join up smoothly with the circular pipe.

The flow through the condenser circuit was measured by means of orifice plates and could be varied between 0 and 60 gallons/minute, the maximum flow thus corresponding to only 3 per cent. of the flow in the main channel. Under these conditions, for any inlet scoop, the static head in the inlet pipe was constant for a given flow regardless of type of exit scoop employed. Similar results were obtained with the exit scoop. The two scoops thus act independently and their performance is investigated separately.

Whilst the static head in the outlet scoop increases steadily with the flow through the scoop, the static head in the inlet pipe, after a preliminary increase shows a sharp drop at higher rates of flow. This drop is due to eddy formation at the forward wall of the inlet and could not be prevented by the provision of guide vanes.

Removal of the slowly moving boundary layer by means of a small centrifugal pump was beneficial but led to a loss of about ro per cent. in the flow. The relatively poor performance of both scoops is mainly due to the fact that they operate within the boundary layer, i.e. a region where there is very marked change in speed with distance from wall. The water filaments entering the scoop have thus very different energy contents and very complicated flow results. 
As a result of mixing losses only about 50 per cent. of the free stream dynamic head is available at the inlet scoop. This was illustrated by means of flow patterns obtained by treating the walls of the scoop with a mixture of soot and oil.

If the velocity distribution in the boundary layer is known, it is possible to estimate the average dynamic head available in the scoop, provided the free stream velocity head is known. This problem was investigated by the author making use of pitot and static surveys. The results are incorporated in a series of design charts covering the types of scoop experimented with.

With the help of these charts, full scale installations can be designed.

As an example, the installation on SS. "America " utilises 36 in. piping and passes 40,000 gallons/minute at ship speed of 24 knots.

Inlet and outlet scoops similar to those tested by the author were utilised. Applying the appropriate corrections, the following values are obtained.

It will be noted that the agreement between calculated total head and estimated resistance of circuit under observed flow conditions is satisfactory.

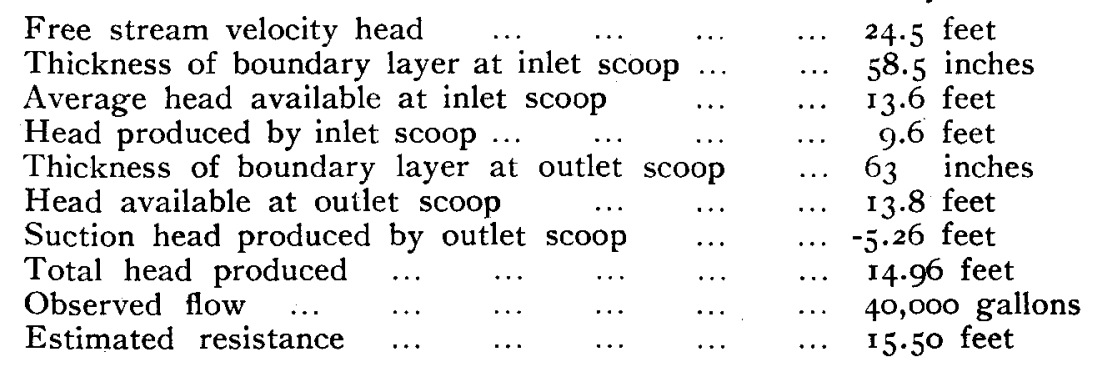

It will be noted that in this design only about half of the free stream dynamic head is available at the inlet scoop and of this a further $3^{\circ}$ per cent. is lost before the water reaches the condenser intake. On the other hand the projecting lip at the exit converts about 30 per cent. of the free stream head into suction.

In conclusion it must be emphasised that the author's tests cover only the efficiency of the scoop from the point of view of water circulation. The additional resistance to propulsion of the ship is not considered. According to some Italian tests, this may amount to as much as ro per cent. of the total ship drag at cruising speed, but appreciably less at maximum speed. On the other hand, the simplicity of the circuit and the absence of any mechanical pumps present enormous advantages.

In the discussion following on the author's paper attention is called to the need of further experiments on the boundary layer effect, including cavitation. It is agreed that boundary layer phenomena are the basis of the operation of the scoop and this is one of the reasons why tests on such circuits cannot be carried out with air as the working medium. This is to be regretted, since the use of air has proved very convenient in other hydraulic investigations.

Calculation of the Second Approximation of the Two-Dimensional Compressible Potential Flow about a Profile by the Janzen-Rayleigh Method. (E. Krahn, L.F.F., Vol. 20, No. 5, 16/6/43, pp. 147-151.) (1 14/3 Germany.)

The calculation of the second approximation to the compressible two-dimensional adiabatic potential flow about a profile at subsonic speeds by the Janzen-Rayleigh method required the solution of

where

$$
\Delta \phi=\left(M^{2} / U^{2}\right)\left(u^{2} u_{\mathrm{x}}+u v\left(u_{\mathrm{y}}+v_{\mathrm{x}}\right)+v^{2} v_{\mathrm{y}}\right)
$$

$\Delta=$ Laplace operator.

$\phi=$ potential of compressible flow.

$M=$ Mach number.

$U=$ incident flow velocity. 
Suffixes $x$ and $y$ denote partial differentiation.

The function $\phi$ must be singly determined and finite in the whole region external to the profile (with the exception of the point at infinity).

In addition, the derivatives of $\phi$ must fulfil the condition of tangential flow at the profile and parallel flow at a great distance from the profile.

This problem has been solved for the circle, the ellipse and the Joukowsky profile, making use of the transformation function of the profile on to the circle together with a knowledge of the potential function of incompressible flow over the whole plane.

Since generally only the velocity distribution at the profile itself is of interest, the author indicates an alternative method in which the calculation is restricted to the region of the profile contour. For this purpose apart from the velocity of incompressible flow at the profile contour only the transformation function of the profile on to the circle and its derivative at the profile need be known, the field outside the profile being neglected.

The method is illustrated by worked out examples covering the case of a cylinder with circulation and an arbitrary profile respectively. Due to the compressibility effects, there is an appreciable increase in lift in both cases.

Contributions to Profile Research-III. Calculation of the Lift Distribution (First Approximation) with a Correction for the Region of the Profile Nose. (F. Kenne, L.F.F., Vol. 2o, No. 5, 16/6/43, pp. 152-170.) (114/4 Germany.)

Known methods for the calculation of the velocity distribution about a given profile are based on conformal transformation of the profile on to a circle. Exact solutions are only possible in relatively few cases for which the transformation function is sufficiently simple. Even then the amount of labour involved may be considerable.

For the general case of an arbitrary profile the approximate method of Theodorsen can be employed, which, however, is fairly complicated and moreover suffers from the defect that the amount of labour involved is practically the same whether the profile is relatively thin or thick.

Since most practical profiles are relatively thin and only slightly curved, a method of approximation based on a source-vortex distribution suggests itself, the distribution being such that the profile contour becomes a stream line for parallel incident flow. This method is naturally more accurate for thin than for thick profiles and will give an exact solution in the limiting case of a line profile of zero curvature.

Provided the maximum thickness (chord ratio is less than .2, and the maximum curvature less than, I), the velocity on the profile contour can be put equal to the $u$ component of the total velocity along the $x$ axis as a first approximation. The singularities are distributed along the same $x$ axis.

The author has tabulated the required source distribution and the resultant induced excess velocity for a series of thickness distributions under symmetrical flow conditions. These excess velocity components are multiplied with the corresponding thickness constants (depending on the form parameter of the profile) and when added to the incident flow velocity in the $x$ direction yield the resultant flow of the symmetrical profile at zero incidence.

Profile curvature and incidence are allowed for by an additional vortex distribution which is also given in a tabular form for various curvature characteristics and angles of incidence, making use of data already published by Birnbaum. The excess velocity components given in the table are multiplied by the corresponding curvature constants and added or subtracted from the stream velocity at the profile, depending on whether the suction or pressure side is considered. 
The resultant velocities on the profile contour are exact only for the case of an infinitely thin profile. They represent, however, a very good approximation for finite thicknesses except in the region of the nose, where linearity between the different components no longer exists.

In this region the difference in velocity between the true contour and the axis (along which the source/vortex distribution is assumed) must be taken into consideration. This is allowed for by a correction in the distribution such that both the tangent and the curvature of the stream line at the front vortex point agree with those of the profile contour. The calculation is first carried out for the particular angle of incidence corresponding to tangential entry. Since the velocities vary in exact proportion with the incidence, the calculation need only be repeated for one further angle of incidence.

A comparison of the distribution of excess velocity as obtained by direct measurement, conformal transformation and the author's approximate method in the case of a symmetrical profile shows excellent agreement.

In conclusion, the author gives a complete lay-out of the method for the rapid calculation of the velocity distribution for an arbitrary profile which does not necessitate any knowledge of the theory and can be carried out rapidly by any competent computor. Provided the six thickness constants of the profile and the four curvature characteristics of the Birnbaum skeleton are known, a complete drawing of the profile is not required.

Pre-Rotation of Landing Wheel Tyres. (C. A. Mason and W. H. Elliott, S.A.E., National Aeronautics Meeting, April 8-9, I943.) (Preprint available.) (1 I 4/5 U.S.A.)

The average life of a $17.00 \times$ i6 aircraft tyre corresponds to about 3,000 miles, say 800 landings and take-offs, averaging $3 \frac{1}{2}$ miles. The rubber lost per mile is over $5^{\circ}$ times that of a $6.00 \times 16$ passenger car tyre (.0057 against .0001 )

Part of this wear is due to the fact that on landing the wheel must be accelerated very rapidly from rest to a peripheral speed of the order of $100 \mathrm{~m} . \mathrm{p} . \mathrm{h}$.

It is obvious that wear would be reduced if the wheel could be spun by some outside agency before contacting the ground. To achieve ground speed (and thus prevent slip) the wheel would have to rotate at over 600 r.p.m. for some time prior to landing. Such high speeds are not feasible, mainly on account of balancing difficulties. If the preliminary peripheral speed is limited to about half initial ground speed, the tread abrasion is reduced by about 25 per cent. and the life of the tyre increased by the corresponding amount. This shows that the possible gain in life is not very great and may be overshadowed by the cost and weight of the pre-spinning equipment.

The simplest method of producing preliminary rotation appears to be direct operation by the relative wind, the tyre being fitted with vanes for this purpose. Flight tests on a B-I $\mathrm{C}$ indicate that tyres of this type (manufactured by Goodrich) accelerated to about half landing speed in about two minutes, the aircraft speed being 150 m.p.h.

A set of these tyres weighs Io $\mathrm{lb}$. more than the standard equipment and the cost is 15 per cent. greater ( $f^{29}$ against $\left.£^{25}\right)$. Bearing in mind that one $\mathrm{lb}$. of extra weight represents a revenue loss under civil operation of the order of $£ 5$, the drive is uneconomical, even if a 20 per cent. increase in tyre life results. (A loss of $\ell_{28}$ in a year's operation, assuming 4,200 hours service per year and a standard tyre life of 800 hours.)

The same line of reasoning shows that mechanical pre-rotation can only be economical if the cost including loss of revenue does not exceed $£ 55$ per year for the aircraft in question.

The authors state that a motor driven device has been tried by one of the largest American aircraft manufacturers, but no details are available. 
New Wind Shield Developments. (A. L. Morse, S.A.E., National Aeronautics Meeting, April 8-9, 1943.) (Preprint available.) (I I 4/6 U.S.A.)

A compressed air catapult is described which enables freshly killed bird carcasses weighing up to 16 lbs. to be projected at speeds up to 400 miles per hour against a wind shield. The experimental panels were plane rectangles, $13 \frac{3}{8}$ in. high and $57 \frac{5}{8}$ in. wide, the experiments covering the effect of bird weight, speed, angle and point of impact, panel temperature, method of support and type of construction of panel. The impact strength of the panel was expressed in terms of the minimum projectile velocity causing penetration.

The experiments indicate that a $\frac{1}{2}$ in. glass-vinyl laminated windshield consisting of outside layers of semi-tempered glass $\frac{1}{8}$ in. thick with a vinyl plastic interlayer $\frac{3}{8}$ in. thick and preceded by a $\frac{1}{4}$ in. fully tempered de-icing glass with an air gap of $\frac{1}{4}$ in. gives complete security against collision with birds weighing up to $4 \mathrm{lbs}$. and a high degree of protection with larger birds weighing up to $20 \mathrm{lb}$.

The net increase in weight over standard double glazed wind shields on a Douglas DC 3 , is of the order of $15 \mathrm{lb}$. and this includes reinforcement of the supporting structure. The optical characteristics are stated to be acceptable.

It is interesting to note that the impact strength of such laminated glass-vinyl shields decrease rapidly with temperature. This is the main reason for adopting the hot air type of de-icer on this screen, the air circulating between the $\frac{1}{2}$ in. panel and the $\frac{1}{4}$ in. tempered glass sheet placed in front.

This ensures that the vinyl plastic interlayer is kept at an optimum temperature of $75^{\circ}$ to $120^{\circ} \mathrm{F}$. depending on plasticizer content. In order to obtain maximum impact resistance under all conditions, this temperature must be maintained even in the absence of any icing.

The mounting of impact resisting wind shields requires special attention as otherwise the shield may be pulled out of the frame. It is essential that the plastic interlayer should extend beyond the edges of the glass and around the entire periphery to provide means for bolting the panel on to the frame. Any tendency of the bolts to tear out of the plastic can be greatly reduced by moulding a thin strip of aluminium (.025 in.) on to the edge. Maximum restraint should be at the ends of the panel and minimum restraint along the top and bottom edges.

Multi-Purpose Aircraft Design Utilising a Detachable Fuselage (Deysher and Hubbs Plane). (American Aviation, Vol. 6, No. 22, 15/4/43, pp. 46-54.) (114/7 U.S.A.)

A revolutionary multi-purpose aircraft design equally efficient in commercial or war transport, utilizing a detachable "fuselage" which can be hauled to and from an airport by an ordinary truck tractor, is announced by Harvey $M$. Deyster and his collaborator, Harold K. Hubbs.

The detachable unit, resembling a standard highway trailer, can be loaded at a plant or military base, towed by truck to an airport, attached to a waiting plane, flown to another airport, and the operation reversed. No time is lost in airport loading or unloading. Alternate designs call for twin-boom aircraft which can haul two trailer or fuselage units at once. Furthermore, the inventor claims that his plane can fly satisfactorily without the unit.

In addition to using the carrier as a shipping container, the operator can capitalize on ability of the plane to fly empty by transporting any number of such units in a one-way stream to an area demanding an emergency hospital, mess halls, emergency light and power stations, machine and repair shops, or signal and transmitting equipment. Thus a hospital, with emergency operating equipment and cots, could be set up in a few hours, hundreds of miles distant, and could be removed as quickly. 
Aerodynamic Performance of the Towed Glider. (A. Klemin and W. C. Walling, J. Aeron. Sc., Vol. 10, No. 6, June, 1943, pp. 185-196.) (114/8 U.S.A.)

In Part $I$ of this paper the authors enumerate certain simple aerodynamic expressions useful in determining the performance of a glider train (tug + one or identical gliders).

Both the rate of climb and level speed of the train is most simply expressed in terms of so-called fictitious speeds, defined as follows :-

where

$$
\begin{aligned}
& V_{\text {fsa }}=\text { fictitious sinking speed of tug }=V / E_{\mathrm{a}}
\end{aligned}
$$

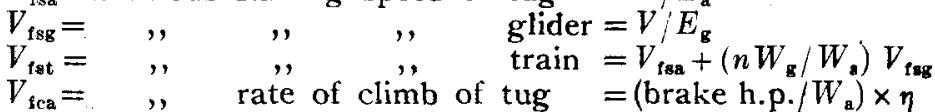

We then have

$$
\begin{aligned}
V & =\text { level flight speed. } \\
E_{\mathrm{a}} & =L / D \text { for tug. } \\
E_{\mathrm{g}} & =L / D \text { for glider. } \\
W_{\mathrm{a}} & =\text { weight of tug. } \\
W_{\mathrm{g}} & =\text { weight of glider. } \\
n & =\text { weight of glider. } \\
\eta & =\text { propulsive efficiency of tug engine. }
\end{aligned}
$$

actual rate of climb of train $=\left(V_{\text {tca }}-V_{\text {tat }}\right)\left\{W_{\mathrm{a}} /\left(W_{\mathrm{a}}+n W_{\mathrm{G}}\right)\right\}$

at the level flight speed $V, V_{\text {tca }}=V_{\text {tat }}$.

By plotting both $V_{\text {ica }}$ and $V_{\text {fat }}$ on a $V$ basis, this speed can be readily determined by the intersection of the curves.

Similarly, the maximum intercept between the two curves will determine the corresponding airspeed for maximum rate of climb whilst the tangent for the origin to the $V_{f s t}$ curve determines the speed for maximum range, on the assumption that the specific fuel consumption is independent of $V$.

Since $V$ must satisfy the expression

where

$$
V=(2 w / \rho)^{\frac{1}{2}}\left(\mathrm{I} / \dot{C}_{\mathrm{L}}\right)^{\frac{1}{2}}
$$

$$
w=\text { wing loading, }
$$

the fictitious sinking speeds also depend on the wing loading, i.e.,

$$
V_{\mathrm{fs}}=(2 w / \rho)^{\frac{1}{2}}\left\{C_{\mathrm{D}} /\left(C_{\mathrm{L}}\right)^{3 / 2}\right\}
$$

By plotting the fictitious sinking speeds at various wing loadings both for the tug and the gliders, it is possible to draw some conclusions on the effect of these two factors on the overall performance. Speaking generally, $W_{\mathrm{g}}$ should be less than $w_{\mathrm{a}}$. If, however, only a single small glider is attached to a fast heavy tug, the cruising speed is affected least by adopting a high wing loading for the glider. Although a reduction of the wing loading of the tug below conventional figure would increase the rate of climb, the accompanying drop in the cruising speed of the train might become dangerous.

From the above it appears that definite conclusions can only be drawn from worked out examples and for this purpose the author selects the Lockheed Lodestar towing one to three gliders each with a payload of the same order as that of the tug for zero range.

The structural weight of the glider is based on that of the Lodestar without engine nacelles.

As the stalling speed of the Lodestar is $93 \mathrm{~m} . \mathrm{p} . \mathrm{h}$. the minimum level flight speed of the glider train was arbitrarily fixed at 1 I 5 m.p.h. This, together wit! the need of a low landing speed of the disconnected glider, led to a choice of $20 \mathrm{lb} . / \mathrm{sq}$. foot for the wing loading of the glider (aspect ratio 12).

Other pertinent data are collected in the following table:- 


\begin{tabular}{|c|c|c|c|c|c|}
\hline \multirow{2}{*}{\multicolumn{3}{|c|}{ Gross weight (th ) }} & \multicolumn{2}{|r|}{ Tug. } & \multirow[t]{2}{*}{ Glider. } \\
\hline & & & & & \\
\hline Take-off & $\ldots$ & $\ldots$ & $\ldots$ & 18,500 & - \\
\hline Landing & $\ldots$ & ... & $\ldots$ & 17,500 & I 3,800 \\
\hline Weight empty & $\cdots$ & ... & ... & 12,000 & 7,300 \\
\hline Crew and equipment & $\ldots$ & $\ldots$ & $\ldots$ & $44^{\circ}$ & $44^{\circ}$ \\
\hline Payload & $\ldots$ & ... & $\ldots$ & $\begin{array}{l}5,060 \\
\text { (up to } 400 \text { miles) }\end{array}$ & 6,060 \\
\hline H.P. & $\cdots$ & $\cdots$ & $\cdots$ & $\left\{\begin{array}{l}2,400 \text { (take-off) } \\
\mathrm{I}, 400 \text { (cruising) }\end{array}\right.$ & - \\
\hline Wing loading ... & $\cdots$ & $\cdots$ & $\cdots$ & $33.6 \mathrm{lb} / \mathrm{sq} . \mathrm{ft}$. & $20 \mathrm{lb} \cdot / \mathrm{sq} \cdot \mathrm{ft}$ \\
\hline Aspect ratio $\ldots$ & $\ldots$ & $\ldots$ & $\ldots$ & $7 \cdot 78$ & I 2 \\
\hline Profile drag coefficien & & $\ldots$ & $\ldots$ & .009 & .009 \\
\hline Total parasite drag c & coefficic & & $\ldots$ & $.02 \mathrm{I}$ & .0112 \\
\hline Nacelle drag coefficie & & $\ldots$ & $\ldots$ & .007 & - \\
\hline Normal fuel load & $\ldots$ & $\ldots$ & $\ldots$ & $3,860 \mathrm{lb}$ & - \\
\hline With extra tanks & $\ldots$ & $\cdots$ & $\cdots$ & $5,700 \mathrm{lb}$ & 一 \\
\hline Max. range (normal $t$ & $\operatorname{tanks)}$ & $\ldots$ & $\ldots$ & 1,800 miles & - \\
\hline Payload (correspondin & ng) & $\cdots$ & $\ldots$ & $2, \infty 00 \mathrm{lb}$ & - \\
\hline Max. range (extra ta & anks) & $\ldots$ & $\ldots$ & 2,800 miles & - \\
\hline Payload (correspondin & ng) & $\ldots$ & $\ldots$ & None & - \\
\hline
\end{tabular}

The comparison of the Lodestar by itself with a glider train falls under the heading of air speed, rate of climb, range and payload.

Naturally, the first three factors must be less for the train than for the tug alone.

On the other hand, the payload is increased to such an extent that the glider train becomes very attractive for certain purposes.

The following presents a selection from the author's calculations. All the data apply to a constant altitude of 5,000 feet.

(I) Max. speed and climb (Lodestar 18,500 lb.) /(Glider 13,800 1b.) :-

Max. true air speed (m.p.h.) $\quad \ldots \quad \begin{array}{ccccc}260 & \text { Tug ainne. } & + \text { I G. } & +2 \text { G. } & +3 \text { G } \\ 200 & \text { I } 70 & 140\end{array}$

$\begin{array}{llllll}\text { Max. rate of climb (feet/min.) } & \ldots & \text { I,700 } & 700 & 300 & 200\end{array}$

(2) Range and payload (normal fuel tanks) :-

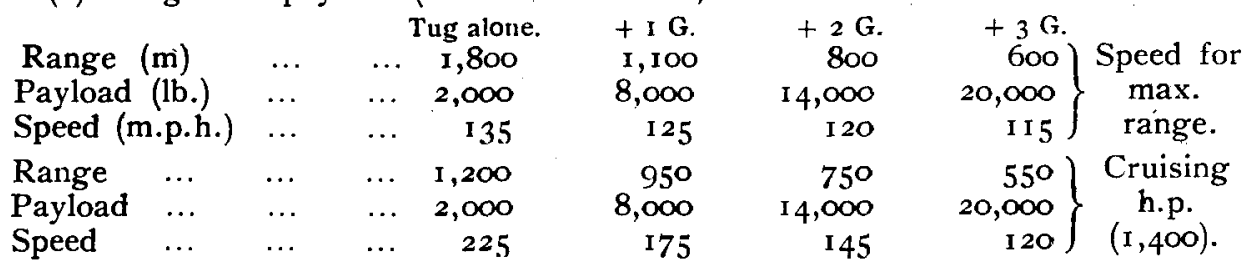

(3) Comparison at a given range is facilitated by the following three factors :Payload factor $P=$ Payload train/payload of tug.

$$
\begin{aligned}
\text { Advantage factor } A & =\frac{(\text { Payload } \times \text { air speed }) \text { train. }}{(\text { Payload } \times \text { air speed }) \text { tug. }} \\
\text { Efficiency factor } E & =\frac{(\text { Payload } \times \text { range } / \text { fuel }) \text { for train. }}{(\text { Payload } \times \text { range } / \text { fuel }) \text { for tug. }}
\end{aligned}
$$

The other factors $P, A$ and $E$ do not vary much with range and the following gives average values up to 800 miles :-

$\begin{array}{ccccc} & \text { Tug alone. } & + \text { I G. } & +2 \mathrm{G} . & +\mathbf{3} \text { G. } \\ P & \mathrm{I} & \mathbf{2 . 2} & 3.4 & 4.5 \\ A & \mathrm{I} & \mathrm{I} .9 & 2.3 & 2.7 \\ E & \mathrm{I} & \mathbf{1 . 4} & 1.6 & 1.6\end{array}$


(4) It will be noted that for a given range both factors $A$ and $E$ are increased for the train in spite of the decreased air speed and increased fuel consumption. This is due to the large increase in payload (factor $P$ ) which overshadows everything else.

(5) This appears at first sight to favour the general utilisation of glider trains for transport work. Difficulties in take-off combined with low rate of climb and horizontal speed added to the relatively restricted range would, however, put up the operative costs very considerably. This will be considered in a subsequent paper by the authors. For military purposes, however, when troops or supplies have to be transported over relatively short distances, the glider train has already proved of enormous advantage.

Future developments will lie in the employment of subsidiary tugs so that the train can be fixed up in the air at a reasonable altitude, refuelling of the tug in the air and the provision of specialised tug engines which are adequately cooled at relatively low air speeds.

Design of Cross Flow Heat Exchangers from Tested Core Sections. (P. A. Scherer, J.S.A.E., Vol. 50, No. I 2, Dec., 1942, pp. 542-548.) (1 $14 / 10$ U.S.A.)

Although this paper deals with the general problems of heat exchangers, it is of special interest for the design of intercoolers in the supercharger circuit of aero engines. It is assumed that experimental data on a core section are available. Such data will usually consist of the following :-

(1) Pressure drop for coolant and supercharger air on a mass flow basis.

(2) "Effectiveness" of intercooler on a mass flow basis with coolant air pressure drop as parameter.

The "effectiveness" is defined as :-

Supercharger Temp. in-Supercharger Temp. out

Supercharger Temp. in-Coolant Temp. in

and this coefficient increases with coolant air pressure drop but decreases with increase in mass flow. An average value is about .5, but the coefficient may range from .4 to .7 depending on circumstances.

The full scale intercooler will have to fulfil certain requirements which may including the following:-

Mass flow, pressure drop, absolute pressure, temperature at entry and exit and length of flow.

The author shows how these requirements can be correlated with the experimental data, making use of the Nusselt equation for heat transfer in cross flow.

A worked out example illustrates the method, the following data being given:

(I) Dimensions of intercooler.

(2) Supercharger circuit.

Mass flow rate.

Entry temperature.

Entry pressure.

Coolant circuit.

Entry temperature.

Entry pressure.

Pressure drop.

Using experimental data on the same type of core but different dimensions, the author obtains the following performance data for this intercooler:-

Supercharger circuit.

Exit temperature.

Pressure drop. 


\section{Coolant circuit. \\ Exit temperature. \\ Mass flow rate.}

The Effect of Environment on Aircraft Engine Design and Performance. (L. T. Miller, S.A.E. National Aeronautics Meeting, April 8-9, 1943.) (Preprint available.) (I $4 /$ i 1 U.S.A.)

The performance of an internal combustion engine operating at a given r.p.m. depends on a variety of factors of which the chief are the intake and exhaust conditions and the temperature of the engine parts.

Bench tests rarely reproduce conditions as they exist when the engine is operated in an aircraft and may be very misleading when comparing engines of different types. What interests the user is the net thrust horse-power available after the drag (including cooling) and propeller losses have been allowed for. At the same lime the weight of the complete installation should be a minimum, and the specific fuel consumption low.

In the past there has been a tendency to judge the possibilities of aircraft engines on test bench performance, it being left to the aircraft designer to provide a suitable mounting and arrange for adequate cooling. Under such conditions the benefits of an inherently light engine structure were often lost by clumsy installation and cooling difficulties. Nowadays, the concept of the aircraft power plant is gaining ground, the unit being designed from the start to function under flight conditions, with all the necessary auxiliaries in position. Light weight of the engine as such, although still of course desirable, is not the single criterion. What matters is the net thrust h.p. delivered per unit weight of the complete installation. Thus a reduction in cooling drag or weight and drag of engine mounting may easily overbalance a heavier specific weight based on test bench results.

In addition, however, to a higher power/weight ratio a low specific fuel consumption is also of importance, since it largely determines the amount of pay load that can be carried. According to the author, much still remains to be done in reducing carburettor metering tolerances and preventing fuel wastage.

With the large power outputs at present in use, even a small percentage saving represents a considerable increase in weight carrying capacity.

Operating Characteristics of Lubrication Systems for an Aircraft Power Plant Installation Under Simulated Altitude Conditions. (Sea level to 40,000 feet.) (H. D. Scrymgeour, S.A.E. National Aeronautics Meeting, April 8-9, 1943.) (Preprint available.) (I I 4/1 2 U.S.A.)

Following a suggestion by the N.A.C.A. that all new lubricating systems should be bench tested under simulated altitude conditions for foaming and pump capacities, Consolidated Aircraft built a mock up of such a system intended for a new bomber. The system consisted of the following elements:-

(I) Engine sump with one gear type of oil pump delivering 20 gallons per minute (electrically driven).

(2) One gear pump supplying ro g.p.m. (electrically driven, simulating cabin supercharger circuit).

(3) One gear pump supplying 1.5 g.p.m. (electrically driven simulating exhaust turbine circuit).

(4) An oil tank of approximately the same size as used in the plane provided with an observation window and electrical heaters.

(5) An oil flow measuring tank. 
(6) An auxiliary vacuum pump connected to main tank, measuring tank and engine pump.

The two auxiliary pumps are arranged in parallel and take their supply from the main feed line between tank and engine pump (before engine pump entry).

Lengths of glass piping for visual examination of the oil flow are inserted at the suction entry of each of the pumps, in the main suction pipe below oil tank and in the common delivery pipe before entry into oil tank. Care was taken to copy the proposed dimensions and lay-out of all the suction pipes with mock up. (No attempt was made to obtain similarity on the delivery side, it being assumed that the pump characteristics are entirely determined by conditions at entry.)

The tests were run at a series of constant oil delivery temperatures $\left(85^{\circ} \mathrm{C}\right.$., $95^{\circ}$ and $75^{\circ} \mathrm{C}$. respectively) at gradual increasing vacuum, the pumps having been previously adjusted to give the required deliveries at atmospheric pressure. This adjustment was not changed during the tests.

Reduction of the air pressure causes a liberation of air bubbles in the oil and at very low pressures there is also a tendency to foam.

With the delivery at the relatively low temperature of $75^{\circ} \mathrm{C}$., observation showed that some solid oil was present in all the pipe lines up to $40,000 \mathrm{ft}$.

At the high temperature $\left(95^{\circ} \mathrm{C}\right.$.), solid oil disappeared at 35 , ,oo $\mathrm{ft}$. in the return line to the tank and at $40,000 \mathrm{ft}$. in the supply line just out of the tank and the line to the turbo pump.

The mixture of oil, foam and air can be handled by the engine pump to ensure adequate lubrication under all conditions up to $40,000 \mathrm{ft}$.

The cabin supercharger oil supply on the other hand was only just sufficient at $40,000 \mathrm{ft}$, whilst the turbo oil supply was definitely below requirement for the cold oil at $40,000 \mathrm{ft}$. It is interesting to note that the presence of as little as $\mathbf{I} .5$ per cent. of water (by volume) increased the foaming considerably, especially at the higher temperature, and this caused the turbo pump to fail at already $\mathrm{I}_{5}, 000 \mathrm{ft}$.

It is proposed for this reason to increase the oil supply to each of those auxiliaries when the system is installed in an aircraft.

Progress Report on Cold Starting Data of the Automobile. Diesel Fuel Division of the Co-operative Fuel Research Committee. (F. C. Burk, S.A.E. War Engg. Production Meeting, Jan. I I-15, 1943.) (Preprint available.) (1 14/13 U.S.A.)

The experiments were carried out on a 6 cylinder 4 cycle Lanova type combustion chamber Diesel which was installed in a cold chamber and could be cooled down to $30^{\circ} \mathrm{F}$. Lubricating oil $\mathrm{SAE} 30$ was used in all the tests. Starting was considered to be satisfactory when the engine continued to run after a period of 30 seconds cranking at a speed varying between 280 and 380 r.p.m. (the lower values corresponding to the lower temperatures).

The five fuels tested had the following characteristics:-

\begin{tabular}{|c|c|c|c|c|c|c|c|c|}
\hline Fuel & Cetane & & Viscosity & & A.S. & 1. Distil & ${ }^{\circ}{ }^{\circ} \mathbf{F}$ & \\
\hline Ref. No. & No. & gravity. & SSU. & I.H.P. & to \%. & $50 \%$ & $90 \%$. & E.P. \\
\hline I & $37 \cdot 5$ & 30.7 & 36.1 & $3^{82}$ & 444 & 508 & 604 & 669 \\
\hline 4 & 46.6 & $44 \cdot 7$ & 30.4 & $3^{11} \mathbf{I}$ & 347 & 394 & 491 & 543 \\
\hline 5 & $44 \cdot 3$ & 28.3 & 49.8 & $45^{2}$ & $5^{28}$ & 608 & 691 & 0 \\
\hline 6 & 50.5 & 34.8 & 37.0 & 484 & 504 & $5^{16}$ & $53^{6}$ & 58 \\
\hline 7. & 45.2 & $34 \cdot 5$ & 35.2 & 333 & 399 & $5^{14}$ & 639 & o \\
\hline
\end{tabular}


The low temperature starting temperature together with cranking times are given below :-

Fuel Ref.
I
4
5
6
7

Starting temp. ${ }^{\circ} \mathrm{F}$. 30 sec. motoring. $5^{8^{\circ}}$

$4 \sqrt{1}$

50

37

49
70 sec. motoring.

52
33
38
31
40

It will be noted that the starting temperatures vary inversely as the Cetane Numbers of the fuels tested, whilst the variation with other properties (density, viscosity boiling range) did not have any apparent influence on the starting.

Further tests are, however, required before the conclusion can be accepted generally. These tests should include other types of engines, both with and without auxiliary starting devices and cover lower temperatures. Under more strenuous conditions, as the temperature approaches the pour point of the fuel, a relationship between fuel viscosity and ease of starting would be expected. If the four variables, Cetane No., gravity, viscosity and volubility are accepted as possible factors influencing cold starting, the fuels should be selected so that only one of these factors is varied at a time. It was found impossible to do this without the use of special blends or dopes which were excluded from the present programme of tests.

Cold Starting Tests on Diesel Engines. (H. R. Porter, Paper read at War Engineering Production Meeting of the S.A.E., Jan. I I to I5, I943.) (1 I 4/I 4 U.S.A.)

Conclusions.

1. The required cranking time is decreased with increase in cranking speed and ambient temperature and decrease in altitude. The lowest ambient temperature investigated was of the order of $20^{\circ} \mathrm{F}$.

2. The starting performance of undoped fuels is predicted by the delay cetane number. With increased cetane number, greater ease of starting is obtained. However, with doped fuels, the delay cetane number may or may not predict the starting performance depending on the particular dope used. Thus ethyl nitrate will improve the cetane number but does not affect the starting performance. The addition, however, of bromo cyclo hexane to a fuel doped with ethyl nitrate gives a starting performance in line with the cetane rating although bromo cyclo hexane by itself does not improve the starting.

Chloropicrin, ampl nitrate, sulphur and ethyl disulfide when added to the fuels give a starting performance in line with the new cetane rating.

3. As indicated by tests on one make of engine, laboratory results may be used to predict service starting performance.

4. Various substances, including chlorine, hydrogen sulfide, amyl nitrate ethyl disulfide, and chloropicrin, are effective in aiding starting when added to the intake air. This finding suggests the use of an auxiliary device, especially designed for the purpose, for aiding in starting under severe weather conditions. However, the effect of such dopes on engine maintenance should first be determined.

Cranking Power and Torque Requirements of Diesel Engines at Sub-zero Temperature. (H. L. Knudsen, S.A.E. War Engg. Production Meeting, Jan. II-15, 1943.) (Preprint available.) (I 14/15 U.S.A.)

The experiments were carried out on a 6 cylinder Cummins Diesel of $67^{2}$ c.i. displacement, the friction h.p. being determined at various speeds and tempera- 
tures with three different kinds of lubricating oil (Grade SAE 30, SAE Io, SAE ro +30 per cent. paraffin).

The following table gives the motoring h.p. five seconds after starting from rest, the engine temperature being as indicated:-

200 r.p.m.

$$
\text { Temp. } \quad-30^{\circ} \mathrm{F} . \quad 0^{\circ} \mathrm{F} . \quad+30^{\circ} \mathrm{F} \text {. }
$$

Motoring h.p.

$$
\begin{aligned}
& 52 \\
& 33 \\
& 10
\end{aligned}
$$

IOo r.p.m.

Motoring h.p.

$\begin{array}{rr}26 & 13 \\ 15 & 6 \\ 6 & 3\end{array}$

3

5
2
$\frac{1}{2}$

Oil.

SAE 30

SAE IO

SAE Io + paraffin

SAE 30

SAE 10

SAE 10 + paraffin

These figures apply to motoring with compression release. If the compression is effective, the motoring h.p. is increased by about 2 h.p. at 200 r.p.m. and I h.p. at roo r.p.m., irrespective of temperature.

Immediately on starting, the motoring h.p. is appreciably higher than the figure given in the table. There is a subsequent rapid decrease, a steady state being reached after about five minutes motoring. This steady motoring h.p. is only about $\frac{1}{2}$ to $\frac{1}{4}$ of the original value, except in the case of the paraffin mixture which shows a much smaller effect, with time especially at the higher temperatures.

Since motoring speeds of at least 100 r.p.m. are necessary for starting, it is clear that the power requirements for cranking at such low temperatures cannot be met by a starting motor circuit of reasonable size and weight even if cold resisting oils of the type SAE ro are employed.

It appears at first sight that the paraffin/oil mixture presents a simple solution of the problem. Unfortunately this mixture is unsuitable for operation at higher temperatures. The difficulty could be met by substituting petrol for the paraffin, since most of the former would evaporate and leave a lubricant of proper viscosity at operating temperatures. 'The objection to this is the need for a fresh supply of diluent which must be added while the engine is still operating to ensure a proper distribution of the lubricant in readiness for the next cold start. In the author's opinion this presents a tedious and expensive operation, which might, moreover, damage the engine unless carried out very carefully. For this reason the author suggests the provision of an electrical oil immersion heater as the simplest solution of the cold starting problem. A similar heater is also recommended for the battery, so as to reduce its internal resistance and obtain the normal discharge current.

Effect of Injection Pump on Cold Starting. (M. M. Roensch, Paper read at War Engineering Production Meeting of the S.A.E., Jan. I I-15, 1943.) (I 1 4/16 U.S.A.)

Of the many problems to be solved during the development of a Diesel engine for use in trucks, cold starting is by no means the least. During the investigation of some of the variables affecting the starting characteristics, it was indicated that there is no satisfactory substitute for the application of heat prior to cranking. Without a good heater, reliable starting at temperatures below $10^{\circ} \mathrm{F}$. is impossible on an engine of this type.

This paper covers the results of a series of cold room tests $\left(-10^{\circ} \mathrm{F}\right.$ ) to determine the effect on cold starting of the following factors:-

A. The quantity of fuel injected at cranking speed.

B. Two types of injection pumps. 
The engine was fitted with a standard 4,000 watt air intake heater which was switched on one minute before the attempted start and left on during the subsequent runs.

The results may be summarized as follows :-

I. For optimum starting, particularly at low cranking speeds, 75 per cent. to 85 per cent. more fuel is required than that delivered by the pump for maximum power, thus indicating the desirability of having some means of increasing fuel delivery for starting purposes.

2. Fuel pumps must have good distribution, even at low cranking speeds, for unless each cylinder will contribute its best power under these conditions cranking speeds will not increase as rapidly as they should and therefore a longer starting time results.

Piston Ring Scuffing as a Criterion of Oil Performance. (G. H. Keller, S.A.E. War Engg. Production Meeting, Jan. II-15, 1943.) (Preprint available.) (114/17 U.S.A.)

The author confirms the opinion now fairly generally held that laboratory tests are useless for determining the lubricating qualities of an oil employed in a modern big duty aircraft engine. The only satisfactory basis for comparison is the mechanical condition of the engine following a power run under standardised conditions. Since the piston rings offer a difficult lubrication problem, the author proposes to use their condition as a criterion for rating the oil, and for this purpose he devised specially severe test conditions high barrel temperature so that variations in oil characteristics will show up within a period of five hours.

All the tests were run on Wright Cyclone C9GC single cylinder fitted with the normal type of six ring piston. Before each test the barrel was carefully lapped, using an old piston and rings so as to ensure a constant surface finish of the cylinder walls. The lubricating oil is supplied to the cylinder by two jets situated on the cylinder skirt on the thrust and anti-thrust sides respectively. Both these jets direct the oil as a solid stream on the underside of the piston, the walls being lubricated by splash from the underside of the piston. Oil thrown off from the crankpin was prevented from entering the cylinder by means of a close fitting baffle fitted with a slot just large enough to clear the connecting rod.

The engine cam and crankcase formed independent wet sumps from which the oil drained into a cooler and was then circulated by means of a pump to the crankshaft, the two oil jets and camshaft, the rate of flow being measured by sharp edged orifices in the respective pipe lines. The total quantity of oil in circulation was originally two gallons in each case, the oil consumption being measured by weighing the residue after the test. Gauges in the cam and crankcase enabled the oil level to be watched, and the test was stopped should the level fall below a certain minimum indicating abnormal oil consumption.

The normal duration of the test run was five hours, prior to which the engine was run in for a period of three hours at gradually increasing load up to a maximum of 134 b.h.p. at 2,500 r.p.m. This was followed by a five hour run at cruising power ( 72 b.h.p. at 2 , 000 r.p.m.) after which the oil system was drained and replenished with the test oil.

During the preliminary runs the following factors were maintained constant:-

Oil inlet temperature $\ldots \quad \ldots \quad \ldots \quad \ldots \quad 180-190^{\circ} \mathrm{F}$.

Crankshaft supply $\quad \ldots \quad \ldots \quad \ldots \quad \ldots \quad \ldots \quad 6.5 \mathrm{lb} . / \mathrm{min}$. at 2,000 r.p.m.

Head temperature (rear spark plug gasket) $375-385^{\circ} \mathrm{F}$.

Cylinder base temperature $\ldots \quad \ldots \quad \ldots{ }_{26}-285^{\circ} \mathrm{F}$.

Oil flow to cylinder jets $\quad \ldots \quad \ldots . \quad \ldots \quad 7.5-8.5 \mathrm{lb} . /$ minute 
After the preliminary run, the cylinder barrel was wrapped round with an aluminium radiation shield and the test proper run under the following conditions after a preliminary warming up period of 30 minutes :-

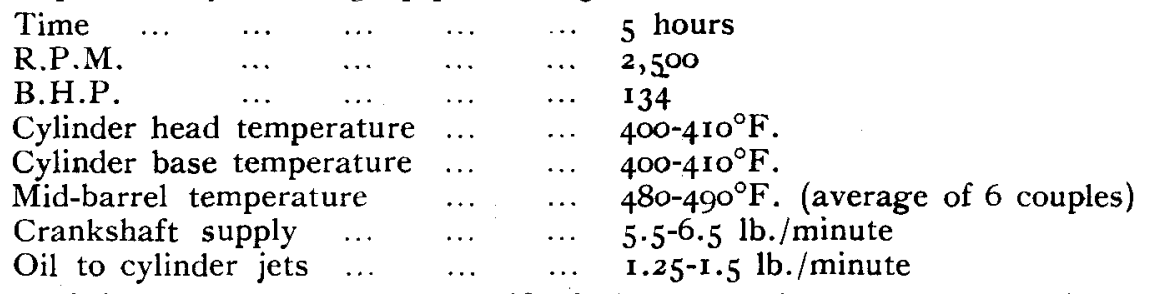

The oil inlet temperature and specific fuel consumption were kept at the same values as during the preliminary runs $\left(180^{\circ}-190^{\circ} \mathrm{F}\right.$. and $.70-.75 \mathrm{lb}$. per b.h.p./ hour respectively).

The fuel used has an octane rating corresponding to iso-octane $+.8 \mathrm{cc}$. TEL and no trace of detonation was observed.

The relative merits of the oils under test were determined by the following factors :-

(1) Condition of rings and piston.

(2) Oil consumption.

(3) Blow-by.

The author claims that the method gives consistent results and is sufficiently arduous to show up marked difference in the behaviour of various types of high class oils in a relatively short running period. Moreover the grading of the oils is in agreement with that based on the much less strenuous conditions of practice necessitating running periods of several hundred hours before marked differences can be established.

Altogether five lubricating oils were tested by the author. In no case did the laboratory grading (viscosity under oxidation factor, etc.) agree with that of the engine tests.

Finishes for Plywood in the Aircraft Industry (Types and Application). (R. B. Anderson, A.S.M.E. Preprint, April 26-28, 1943.) (I I4/18 U.S.A.)

The major requirements of a finishing system of the direct coating type for plywood aircraft surfaces are presented. These include moisture resistance, durability to weathering and hard usage, weight factors, application in the aeroplane factory, refinishing in the field, and the need for film smoothness. A review of the various types of finishes is given, covering both the development and service stages. These types can be classified as:-
(a) Cellulose.
(b) Alkyd.
(c) Phenolic.

Of these the phenolic type appears to be the most promising.

The cellulose type is easy to apply and dries quickly. It has, however, a poor moisture resistance and tends to crack and is considered unsatisfactory by the author.

Alkyd type finishes are relatively new and more experience in the field will be required before a definite judgment can be passed. Its moisture resistance appears, however, to be inadequate. The methods of finish applications are considered together with some of the precautions which must be considered.

Problems Affecting the Use of Wood in Aircraft. (R. W. Hess, A.S.M.E.
Preprint, April 27-28, 1943.) (1 $14 / 19$ U.S.A.)

On the whole, very little has been done by the wood industry so far to develop the permanent acceptance of wood in face of competition with other 
materials. Standardization of grade rules and maintenance of low price are not sufficient, bearing in mind the continued and intensive research for improvement in the quality of metal products.

Continued use of wood in aircraft structures and for some other highly stressed applications, in the face of intense competition from other materials, is dependent in part upon the amount of detailed engineering data that is made available in the near future and upon the extent to which the wood materials and wood products are improved in uniformity and quality.

Following is an enumeration of the measures proposed to stimulate wood use in aircraft:-

I. Wood quality improvement.

a. Segregation of wood (including veneers) into more restricted specific gravity groups.

b. Reduction of veneer and plywood tolerances.

c. Complete control of wood moisture content through all stages of manufacture.

2. Basic data analysis.

a. Study the available strength data of all wood species to determine accurately the various species offering advantages where particular stresses are dominant.

b. Utilize these woods to obtain greater strength/weight efficiency.

3. Structural design data accumulations.

a. Conduct the necessary tests to determine the basic structural desiyn data that have not yet been determined for our native wood species. These include Young's moduli (3) shear moduli (3), Poisson's ratios (6), ultimate and yield strengths for various angles to the grain, and typical stress strain curves.

b. Advance the wood aircraft designs as rapidly as possible, digressing as far from the "conventional" as is necessary to use wood in its most efficient manner.

Theory of the Expanding of Boiler and Condenser Tube Joints Through Rolling. (A. Nadai, A.S.M.E. Preprint, April 26-28, 1943.) (1 14/20 U.S.A.)

Tubes in industrial water heaters, steam boilers, and condensers of turbines are fitted in the holes of adjoining drums or head plates by expanding the tube ends. These are slightly enlarged by means of small revolving rolls. In one large steam condenser many thousands of such tube joints have to be rolled, and in high-pressure boilers these joints must remain tight under several thousands of pounds pressure at high temperatures. The pressure of the revolving rolls creates a radial plastic distribution of stress in the tube wall and around the hole in the adjoining heavy steel plate. After the tube end has been rolled, a system of residual stresses remains locked up near the joints which is essential for its pressure tightness. These plastic states of stress have been investigated for various types of the stress-strain characteristics of the tube metal and steel of the head plates. Simple rules are used for computing the stresses in a moderately thick-walled tube under external and internal pressure, either in the elastic or in the plastic state of stress.

Creep of Metals at Elevated Temperatures (the Hyperbolic Sine Relation Betueen Stress and Creep Rate). (P. G. McVetty, A.S.M.E. Meeting, 26-28/4/43.) (Preprint.) (I I $4 / 21$ U.S.A.)

One of the earliest expressions for stress-creep ratio is the Norton formula

$$
v=v_{1}\left(\sigma / \sigma_{1}\right)^{n}
$$


where

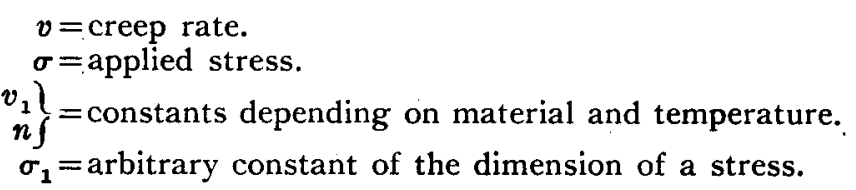

This formula is convenient as giving a straight line when plotted on a log basis, but experience has shown that it over-estimates the stress in the lower creep range. As a result of theoretical considerations, Nadai has proposed a hyperbolic law of the form

$$
v=v_{\mathrm{o}} \sin h\left(\sigma / \sigma_{\mathrm{o}}\right)
$$

where $v_{0}$ and $\sigma_{0}$ are constants depending on the material and temperature, which have to be determined from creep tests at two temperatures.

A graphical solution for this purpose is described and a chart is given to facilitate the calculation. The hyperbolic formula is especially useful if the experimental points cover the high stress range $(\sim 3, \infty 00$ psi) and extrapolation is required to very low creep rates. Thus in turbine design, the maximum allowable creep is usually of the order of . I per cent. per 100,000 hrs. or roughly .001 per cent. per 1,000 hrs. (neglecting higher rate of initial creep). Assuming that only test data at 3,000 and 4,000 psi are available, extrapolation by the power series gives a limiting stress of 1,260 psi for the allowable creep for a certain steel. The hyperbolic formula, on the other hand, is within ro per cent. of the very much lower experimental value of 300 psi.

Comparison with other available experimental data is equally satisfactory, but since accurate figures are only available for a relatively restricted number of materials and temperatures, more data will be required before the hyperbolic law can be accepted generally.

Operating Temperature and Stresses of Aluminium Aircraft Engine Parts. (E. J. Willis and R. G. Anderson, National Aeronautics Meeting, S.A.E., April 8-9, 1943.) (Preprint available.) (1 1 4/22 U.S.A.)

Aircraft engines must be designed to give the maximum possible output at the lowest possible weight.

Further improvements must be based on a more accurate knowledge of the thermal and mechanical stresses met with in operation. The authors classify the engine structural parts made of aluminium under the headings of cylinder head, piston and crankcase, and indicate possible lines of development in each class.

As regards the cylinder head, operative temperatures are most conveniently estimated by a Brinell hardness survey, the connection between hardness, temperature and exposure time having been obtained by a previous calibration.

The stresses under which the head operates are partly of the nature of prestresses due to the assembly (shrink fits), and partly cyclic stresses imposed by the combustion cycle and rocker gear operation. Stress concentration because of mating parts or sharp radii are very difficult to allow for. Such concentrations arise specially on the barrel threads and at the top of the barrel. Care should be taken that all threads match correctly at the operating temperature rather than at shrink or room temperature.

The proportion of aluminium head thickness to steel barrel thickness in the vicinity of the joint should be at least in the ratio of $4.2 / \mathrm{r}$. The connection to the exhaust pipe should be in the form of a flange, and studs in the aluminium keeping the exhaust pipe as flexible as possible. Since the cylinder heads flex considerably in relation to each other during actual operation, a flexible joint is necessary. 
In the case of liquid cooled cylinders, the head jacket must be made of very ductile material, otherwise the first explosion which the head undergoes may strain the jacket material past its yield point at point of stress concentration and then produce cylinder distortion.

\section{Pistons.}

Operating temperatures are again best obtained by a Brinell hardness survey, whilst the corresponding strain distribution are given by a brittle lacquer method.

The strength of the wrist pin and connecting rod have a considerable effect on the piston stresses. The limiting load. which the piston will support is determined by the stress concentrating at the inside of the wrist pin boss brought about either by inward deflection of the piston crown or bending of the wrist pin. Short pins of large diameter, in spite of the higher load per unit projected area, are therefore preferable.

Ringland distortion under load is also of great importance. This can be readily measured at room temperature and will generally be slightly less at the working temperature due to redistribution of stress. Most of the stresses in a piston are of a fatigue nature and care must be taken not to exceed the fatigue limit at the operative temperature.

A simple form of testing machine is described in which the full scale temperature distribution in the piston can be imitated, whilst cyclic loads up to $100,000 \mathrm{lbs}$. can be applied at a frequency of $1,300 \mathrm{cycles} / \mathrm{sec}$. The prevention of piston distortion appears to be the foundation of a successful design.

\section{Crankcase.}

The main difficulty in light alloy crankcase is the provision of holding down studs for the cylinder barrel. Care should be taken that any bending stresses in the crankcase do not pass the section in which the studs are placed. Usually the stress distribution in the studs varies considerably. A ring nut for holding down the cylinder, such as used on the German D 6or engines, gives a much more uniform distribution.

Caution in the use of ribs in crankcases cannot be too highly emphasised. Thin round topped ribs in conjunction with a diaphragm should not be used. A better use of the metal results if only ribs are used in the construction, since these can now be made broader and stronger.

Elevated Tèmperature Ageing of $24 S$ Aluminium Alloy. (P. P. Mozley, J. Aeron. Science, Vol. Io, No. 6, June, 1943, pp. 180-184.) (114/23 U.S.A.)

The ageing of strong Al. alloys at elevated temperatures is not a new process and the possible improvements in physical propertis have been frequently studied.

The fear of corrosion difficulties and lack of precise data on the heat treatment have delayed application of the process.

For this reason the author carried out detailed tests on $24 \mathrm{~S}$ alloy as commonly employed in aircraft construction. It appears that optimum results are obtained for this alloy when ageing at $375^{\circ} \mathrm{F}$. for eight hours. This treatment will raise the yield point by about $5^{\circ}$ per cent. and the ultimate tensile by ro per cent., whilst the original elongation is approximately halved.

The maximum physical properties obtainable by ageing depends to a considerable extent on the inherent stress distribution due to cold working after solution heat treatment but prior to ageing. For consistent results the amount of cold working should correspond approximately to that required to produce a I per cent. permanent set by stretching or 2 per cent. reduction in thickness by rolling.

The corrosion resistance of aluminium covered sheet of $24 \mathrm{~S}$ alloy is not seriously affected by the ageing at elevated temperature, provided the thickness of the sheet is greater than .032 in. 
The corrosion resistance of bare $24 \mathrm{~S}$ alloy is, however, appreciably lowered and elevated temperature ageing in thicknesses below $3^{-16 t h}$ in. is not recommended because of the increased tendency of inter-crystalline corrosion.

It will thus be noted that hot temperature ageing of $24 \mathrm{~S}$ alloy presents important advantages without any risks of excessive corrosion. The only drawback is the need for a close control of the degree of prior cold-working if consistent results are to be obtained.

Significance of the Secant and Tangent Moduli of Elasticity in Structural Design. (D. S. Wolford, J. of Aeron. Sciences, Vol. Io, No. 6, June, I943, pp. 169-179.) (1 $14 / 24$ U.S.A.)

The author deals with the problem of designing beams and columns of structural materials that have no well defined yield point and which must be used above their proportional limit.

Under these conditions we have to differentiate between three kinds of modulus of elasticity.

$$
\begin{aligned}
& E_{\mathrm{o}}=\text { Young's modulus (lb. psi)=stress/strain under initial conditions } \\
& \text { (proportionality). } \\
& E_{\mathrm{s}}=\text { secant modulus =stress/strain under actual conditions. } \\
& E_{\mathrm{t}}=\text { tangent modulus }=\text { slope of stress/strain curve at a particular load } \\
& \text { under actual conditions. }
\end{aligned}
$$

As is well known, the buckling load $P$ of a freely supported uniform strut is given by the Euler equation $P=\pi^{2} E I / l^{2}$ on the assumption that the elastic limit is not exceeded, i.e., $E=E_{0}$. ratio

Putting $J=i^{2} F$ where $i=$ radius of gyration of section and $\lambda=L / i=$ slenderness

$$
\begin{gathered}
P=\pi^{2} E_{0} F / \lambda^{2} \\
\text { i.e., } P / F=\text { buckling stress }=\pi^{2} E_{0} / \lambda^{2} \text {. }
\end{gathered}
$$

As $\lambda$ decreases, the buckling stress therefore would increase indefinitely (Euler hyperbola).

As a matter of fact, $E_{0}$ will only remain constant till the stress has risen to the proportionality limit. If buckling takes place at this point, the compression stresses along the inner (concave) side of the strut will increase according to the tangent modulus of the section. The outer (stretched fibres), however, will have their compression reduced and will thus operate under $E_{0}$ conditions. As a result, the stress distribution is no longer symmetrical about the neutral axis of the section and the strut behaves as if it possessed a so-called "reduced " modulus which is a function of $E_{\mathrm{o}}$ and $E_{\mathrm{t}}$.

In the case of a solid rectangular section

$$
\text { - } E_{\mathrm{r}}=4 E_{\mathrm{t}} E_{\mathrm{o}} /\left(\sqrt{ } E_{\mathrm{o}}+\boldsymbol{v}^{\prime} E_{\mathrm{t}}\right)^{2}
$$

whilst for an idealised $H$ section (infinitely thin flanges and no web)

$$
E_{\mathrm{r}}=2 E_{\mathrm{o}} E_{\mathrm{t}} /\left(E_{\mathrm{o}}+E_{\mathrm{t}}\right)
$$

The buckling load of short struts is then given by

where $E_{r}=$ reduced modulus of section.

$$
\sigma_{\mathrm{B}}=\pi^{2} E_{\mathrm{r}} / \lambda^{2}
$$

So far $E_{r}$ has only been worked out for a few sections and in view of the large number of different sections employed in practice, the labour involved to cover the whole range would be prohibitive.

The question naturally arises whether some simpler criterion for a material suitability for short columns might be devised.

For this purpose the author carried out complete tension and compression tests on two tempers of 25 gauge $(\sim .02 ")$, type $3^{\text {OO }}(17-7)$ high tensile stainless steels. These tests were carried out both on longitudinal and transverse speci- 
mens, both as cold rolled and after stress relieving. Stress-strain, tangent and secant modulus data were obtained in curve form.

Next, column tests were made on corrugated sheet of the same material.

The specimen varied in slenderness ratio from approximately 30 to 300 and were loaded as columns with knife edge end conditions.

The curves of buckling stress against slenderness ratio were found to be in good agreement with Euler curves based on tangent modulus, showing that for this type of section, at any rate, $E_{t}$ forms a satisfactory criterion, provided premature crippling due to local unstability is avoided.

The author also shows that for hollow sections with most of the material remote from the neutral axis, $E_{\mathrm{r}}$ under pure bending is identical with the secant modulus $E_{\mathrm{s}}$. A knowledge of the tangent and secant modulus will thus enable the designer to tackle short column problems with a certain amount of confidence.

It must, however, not be forgotten that the crippling loads given by the formulz are upper values which are only approached if premature failure due to local instability is prevented, i.e., the failure must be of the Euler type.

Behaviour of Plywood Under Repeated Stresses. (A. G. Dietz and H. Grinsfelder, Trans. A.S.M.E., Vol. 65, No. 3, April, 1943, pp. 187-191.) (I 14/25 U.S.A.)

The material employed in these tests was aircraft quality birch veneer, I-I6th in. thick. Two kinds of adhesives were employed, the veneer being laid up and bonded as follows :-

a. Phenolic resin film: Two-ply laminated, 3-ply laminated, 3-ply plywood.

b. Urea resin solution: Three-ply plywood.

Both laminated and standard plywood construction were investigated under bending fatigue. Laminated wood (constant grain direction) resembles solid wood in that the bending stress varies uniformly across the section with a maximum shear stress at the centre. In the case of 3-ply plywood, however (varying grain direction) the bending stress is concentrated in the two outer layers where the grain is parallel to the axis, whilst the shear stress reaches a maximum at the glue joints.

Various types of specimen were tested to determine the steps which would most consistently yield fractures free of split and would at the same time provide constant bending stress over a representative cantilever length.

This was finally achieved by adopting a tapered plan form for the specimen, the wider end piece being rigidly clamped whilst the narrower head was attached to the connecting rod of the reciprocating test machine operating at $1,75^{\circ}$ r.p.m. Exact dimensions of the test specimen are not given.

To provide standards of comparison, static bending and tension specimen were cut from each sheet of material adjacent to the points from which the fatigue specimens were cut. The static bending specimens were one inch wide and were tested on a span 16 to 20 times the depth of the specimen. Glue lime shear tests were carried out in the standard manner from one inch wide specimen cut from the fatigue specimen after failure and from the bending control specimen. Each fatigue specimen was first calibrated by loading the free end and obtaining a load deflection curve. From this the modulus of elasticity and the stress corresponding to a given deflection were calculated.

The throw of the connecting rod was then adjusted to produce a stress equal to a given fraction of the ultimate static fracture and the number of stress reversals to crack the specimen was noted.

The following represents a summary of the results:- 


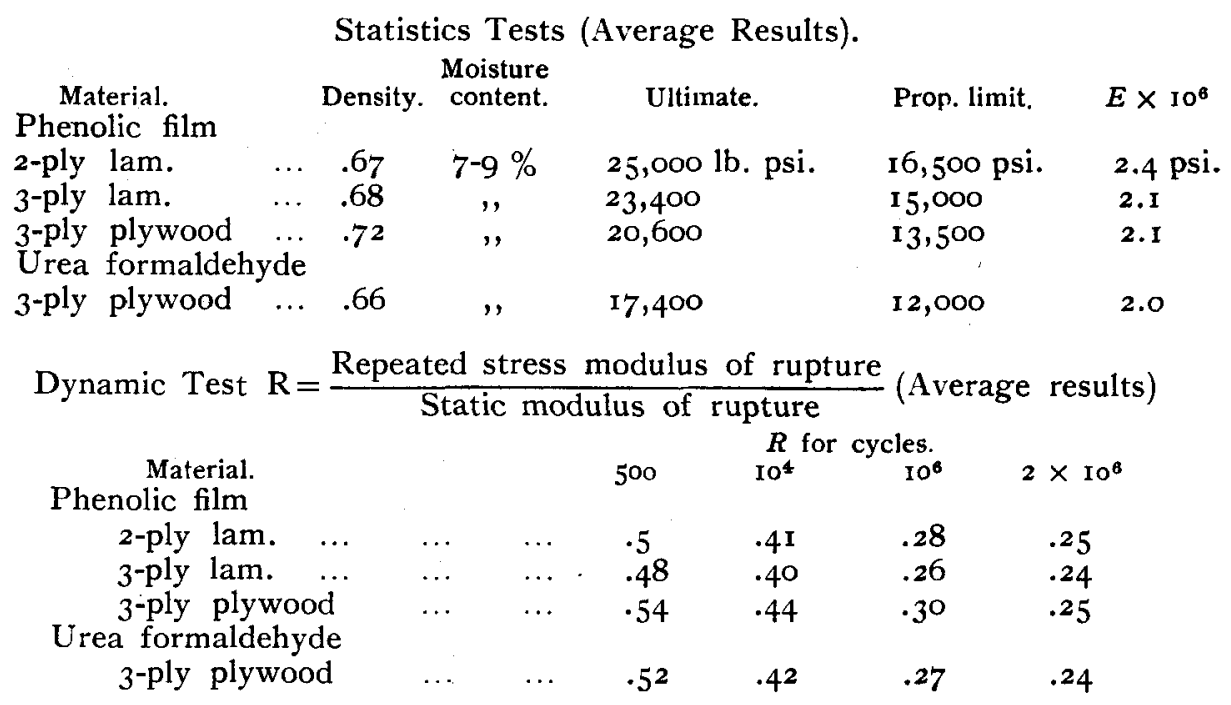

Periodic examination of the specimen during the test runs revealed little tendency for the board to fail and the veneers to separate. After the outer plies had cracked through to the glue line, delamination did occur in a few instances. This tendency was somewhat more prevalent in the plywood than in the laminated materials.

It will be noted that irrespective of construction and type of glue, a life of at least $2 \times 10^{6}$ reversals can be expected, provided the repeated stress does not exceed 25 per cent. of the ultimate static value.

The actual repeated stress value for this life will, however, be highest for the two-ply laminated wood since it possesses the highest ultimate static stress.

High Density Laminated Plywood. (M. Finlayson, Trans. A.S.M.E., Vol. 65, No. 3, April, I943, pp. 193-199.) (I I4/26 U.S.A.)

In normal plywood, subdivision and reassembly add little to the aggregate strength of the resultant material. The assembly, however, ensures the absence of local flaws and crooked grain and thus represents the best that can be obtained with wood of a given type. It appears that the resin, as used in normal manufacture, plays only in a minor part in improving the mechanical properties.

A large increase in strength of the wood, however, arises if the veneers are densified during assembly by using pressures much higher than are usual in ordinary plywood manufacture. By controlling the pressure, temperature and moisture content during assembly, any degree of densification up to $\mathrm{x} .4$ can be readily obtained. The thermosetting adhesive cures whilst the wood is in the compressed condition, and if sufficiently thin veneers are used there is practically no spring back after the material has cooled and is removed from the press. The data on strength characteristics presented by the author refer to the so-called unimpregnated type of high density wood, made from $1 / 3^{2}$ in. birch veneer using a film type adhesive (Tego bond). The grain direction of all the plies is parallel (laminated wood). The density of the material varied about .8 and 1.3 , depending on the manufacturing process adopted. The boards supplied were approximately $\mathrm{I}$ in. thick.

The tests show that both the tensile and compressive strength varied directly as the density of the material, the resulting mean line passing through the origin.

The strength for weight ratio is thus constant $(24,700$ psi under tension and I 5,000 psi under compression for wood of unit density). 
There is thus no inherent advantage on a weight basis on using the heavier wood. The density should, however, not fall below .8 to ensure adequate bonding (film stronger than wood). On a volume basis, however, the higher density wood presents important advantages.

Tension.- The high density wood has no yield point and can be loaded up to the breaking limit without the appearance of permanent distortion.

If comparison with metals is carried out at the yield point of the latter, high density laminated wood on a weight basis is about six times as strong as low carbon steel and 5o per cent. stronger than Alclad. Even if we compare ultimate strength in each case, the densified wood still heads the list on a weight basis, as is shown in the following table:-

$\begin{array}{llccc}\text { Material. } & & \text { Density. } & \text { Ultimate. } & \text { Ultimate } / d . \\ \text { High density wood } & \ldots & .8-1.3 & \text { depends on } d & 24,700 \\ \text { Steel, heat treated } & \ldots & 7 \cdot 75 & 175,000 & 22,600 \\ \text { Al. alloy } \quad \ldots & \ldots & 2.81 & 69,000 & 21,400 \\ \text { Mg. alloy } \quad \ldots & \ldots & 1.78 & 43,000 & 24,200\end{array}$

Compression.-The high density wood does not show the same superiority over other materials, but is still well up on the list ( 5,000 psi against 20,700 for Al. alloy).

Tonsion.--The ultimate shear strength under torsion is only about $1 / 9$ that of aluminium. The resistance to torsional shock is however about the same. Thus, if internal damping is neglected, the max. shear stress (developed if a circular shaft of radius $r$ is suddenly given an angular velocity $w$ ) is given by

where

$$
f=r w(E d)^{\frac{1}{2}}
$$

$$
\begin{aligned}
E & =\text { modulus of rigidity. } \\
d & =\text { density. }
\end{aligned}
$$

Using the following values :-

$$
\begin{array}{lcc} 
& \text { Aluminium. } & \text { High Density Wood. } \\
E & 4.2 \times 10^{6} & .18 \times 10^{6} \\
d & 2.85 & .95 \\
& (E d)^{\frac{1}{2}} \text { al. } /(E d)^{\frac{1}{2}} \text { wood }=8.4
\end{array}
$$

which is approximately the same as the ratio of the shear strength. The high interval damping of the wood presents an additional advantage since it evens out stress peaks.

EFFECT OF Morsture.-Exposure to water vapour and especially immersion water causes a considerable change in thickness and smaller changes in the other dimensions. The dimension in the direction of the grain is scarcely altered, whilst the thickness may increase up to $5^{\circ}$ per cent. This increase in thickness is accompanied by an increase in weight of the same order. In spite of these large dimensional changes, there is no tendency to delamination.

High density plywood of the type tested must therefore be thoroughly protected by an imperious coating before it can be utilised under conditions of high humidity.

The material has proved an excellent material for aircraft propellers of large power output, a three-bladed I,750 h.p. propeller weighing about $300 \mathrm{lb}$. less than a metal propeller of similar output.

In addition to this saving in weight, the high density wood propeller is less sensitive to notches and dents, and has excellent fatigue resistance and damping characteristics.

It is probable that further extensive uses for this material will be found once the large press equipment required will become more generally available. 
Heating Wood with Radio-Frequency Electric Power. (I. P. Taylor, Trans. A.S.M.E:, Vol. 65, No. 3, April, 1943, pp. 201-212.) (1 14/27 U.S.A.).

If an alternating E.M.F. is applied to a perfect condenser, both the current and voltage are permanently out of step by $90^{\circ}$ and no power is consumed.

If the dielectric is imperfect (e.g., wood), the circuit behaves as if an " equivalent " resistance $R_{\mathrm{p}}$ were placed in parallel with a perfect condenser of the original capacity. $R_{\mathrm{p}}$ depends on the frequency.

The total current now leads the voltage by less than $90^{\circ}$ and has both a resistance and capacity component ( $i_{\mathrm{R}}$ and $i_{\mathrm{C}}$ respectively).

The power generated is now given by

where

$$
P=i_{\mathbf{R}}^{2} R_{\mathbf{p}}
$$

$$
\begin{aligned}
R_{\mathrm{p}} & =\mathrm{I} / 2 \pi f c \times \mathrm{I} / \cos \theta \\
C & =\text { capacity of condenser. } \\
f & =\text { frequency. } \\
\cos \theta & =\text { power factor. }
\end{aligned}
$$

The power factor can easily be measured by means of a special meter. It depends mainly on $f$ and also slightly on the type of wood.

The following table represents average values:-

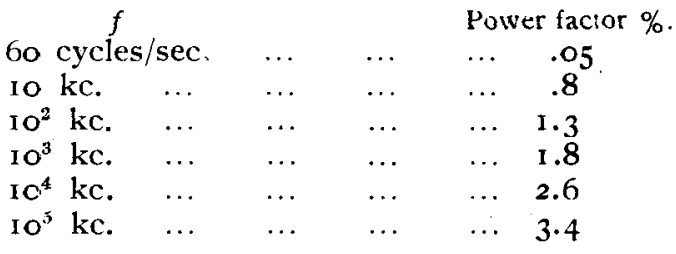

If

$$
\begin{aligned}
v & =\text { volume of wood in cc. } \\
p & =\text { specific heat. } \\
c & =\text { density. } \\
\Delta t & =\text { temperature rise in }{ }^{\circ} \mathrm{c} . \\
t & =\text { time required (sec.). }
\end{aligned}
$$

Then

$$
P=\frac{4.18 \times p c \times \Delta t \times v}{t}
$$

The author gives $P / v$ as a function of $t$ and $\Delta t$ for two values of $p c(.25$ to .35 respectively).

Most woods fall between these limits. Knowing $P$ and calculating $R_{\mathfrak{v}}$ from $(2), i_{\mathrm{R}}$ and hence $E$ can be calculated.

In a worked out example

$$
\begin{aligned}
& P=6,000 w . \\
& C={ }_{15} \circ \mu \text { farads. }
\end{aligned}
$$

If $f=60$ and power factor $.05, R_{\mathrm{p}}=354 \times 10^{6}$ and $E$ becomes $1.46 \times 10^{6}$ volts which is clearly impracticable.

On the other hand, if $f=10^{6}$ cycles/sec., $R_{p}=20,200$ and $E=1 \mathrm{I}, 000$ volts.

For a given power output $E$ thus varies inversely as the square root of the frequency, and in order to prevent danger of flash-over, as high a frequency as possible should be used.

The upper limit at present is fixed by tube efficiency by the generator and difficulties of current distribution. At the moment, IO-I 5,000 volts are usually employed.

The following are some of the advantages claimed for the new process of electric heating.

(1) More uniform heating throughout the mass.

(2)Thick sections can be heated quickly and the process can be adapted to hot glued joints. 
(3) Presses for such work are simplified.

(4) Freedom from internal stresses, since uniform temperature implies uniform compression.

Disadvantages are mainly due to the need of adequate electrode insulation on the press, and guarding against flash-over. The author describes various methods of overcoming these difficulties. One obvious solution is to use the electric method outside the press simply to bring the material up to the working temperature. It is then inserted into the press and left to cure under the action of steam alone.

This method is adopted in the manufacture of "compreg " wood laminated Fropellers.

Limits in the Accuracy of the Determination of the True Vertical in an Aircraft, by taking the Average of Readings of the Apparent Vertical. (E. Timmel, L.F.F., Vol. 20, No. 5, 16/6/43, pp. I7I-I74.) (I 14/3I Germany.)

Astronomical position finding depends on a knowledge of the true vertical; an error of.$I^{\circ}$ in the latter causing an uncertainty of $11 \mathrm{~km}$. in the position.

No artificial horizon at present in use claims an accuracy of this order and a pendulum or spirit level is ruled out on account of its readings being seriously affected by even small changes in aircraft speed. As a result, the only practical procedure is to average out the apparent vertical readings over a period of time.

The author considers the errors likely to arise in this case, assuming that the aircraft flies on a straight course and that the disturbance acceleration is less than $g / 60$ (error of individual apparent vertical readings not more than $1^{\circ}$ ).

If

we have

$$
\begin{aligned}
b_{\nabla} & =\text { vertical component of disturbance acceleration. } \\
b_{\mathbf{H}} & =\text { horizontal component of disturbance acceleration. } \\
\alpha & =\text { deflection of apparent vertical, }
\end{aligned}
$$

$$
\begin{gathered}
\tan \alpha=\frac{b_{\mathrm{H}}}{\left(g+b_{\mathrm{\nabla}}\right)} \\
\text { i.e., } \alpha=\frac{b_{\mathrm{H}}}{g}-\frac{\left(b_{\mathrm{H}} \cdot b_{\mathrm{\nabla}}\right)}{g^{2}}
\end{gathered}
$$

The error over a period of time $T$ is thus given by

$$
\bar{\alpha}=\left(\begin{array}{c}
\mathrm{I} \\
\bar{T}
\end{array}\right) \int_{0}^{\mathrm{T}}\left(\frac{b_{\mathrm{H}}}{g}\right) d t-\left(\frac{\mathrm{I}}{T}\right) \int_{0}^{\mathrm{T}}\left(\frac{b_{\mathrm{H}} \cdot b_{\mathrm{v}}}{g^{2}}\right) d t .
$$

The author shows that under the specified conditions, the second integral is less than $\mathbf{I}^{\prime}$ and can therefore be neglected.

Disturbances $b_{\mathrm{H}}$ can be classified into two groups.

Group I.-These disturbances are accidental and due to changes in the actual flight path from the ideal (constant direction and speed). They continually vary in amount and direction (gusts, swinging of compass, variation in power output), and the mean value over a length of time approaches zero under automatic pilotage or careful hand control.

The actual error is conveniently divided into a longitudinal and lateral component of the deviation from the true vertical. These are given respectively by

$$
\begin{aligned}
\boldsymbol{x}_{\mathrm{L}}(\text { longitudinal }) & =\frac{\Delta v_{\mathrm{g}}}{g T} \\
\left.\alpha_{\mathrm{q}} \text { (lateral) }\right) & =\frac{v_{\mathrm{g}} \Delta X}{g T}
\end{aligned}
$$

where $\Delta v_{\mathrm{g}}=$ difference in ground speed in $\mathrm{km} . / \mathrm{h}$. at beginning and end of interval $T$ (minute). 
$\Delta X=$ angle of rotation (degrees) of flight path tangent from set course over the interval $T$ (minute).

Expressing $\alpha$ in minutes of arc, the above expression becomes

$$
\begin{aligned}
& \alpha_{\mathrm{L}}=\left(\frac{\Delta v_{\mathrm{g}}}{T}\right) \times 1.7 \mathrm{I} \\
& \alpha_{\mathrm{a}}=\left(\frac{v_{\mathrm{g}} \Delta X}{T}\right) \times .03
\end{aligned}
$$

Thus for an error of $\sigma^{\prime}$ in $\chi_{\mathbf{L}}, \Delta v_{\mathbf{g}} / T$ must not exceed about 4 . For a similar error in $\alpha_{a}, v_{\mathrm{g}} \times(\Delta X / T)$ must not exceed 200 , i.e., at $500 \mathrm{~km} . / \mathrm{h}, \Delta X / T$ must not exceed $.4^{\circ}$ if the average is taken over one minute.

NOTE. - The above expression for $\alpha_{a}$ neglects the effect of the rotation of the flight path with respect to the great circle. This will be included in Group II, Section 2, below.

Group II.-Disturbances under this heading are not accidental and cannot be eliminated by averaging. They result in a steady deflection of the apparent vertical and may be due to any one of the following causes:-

(1) Coriolis acceleration due to rotation of the earth.

(2) Acceleration due to curvature of loxodrome (constant course).

(3) Changes in the wind velocity.

(1) The horizontal component of the acceleration is given by

where

$$
b_{\mathrm{c}}=2 w v_{\mathrm{z}} \sin \phi,
$$

$$
\begin{aligned}
v_{\mathbf{g}} & =\text { ground speed. } \\
\phi & =\text { latitude. } \\
w & =\text { angular velocity of the earth }=.25 \% \text { minute. }
\end{aligned}
$$

The resultant deflection of the apparent vertical is given by $b c / g$ and necessitates a correction in the altitude of a given star by the amount $b c / g \sin \tau$ where $\tau$ is the azimuth. At $v_{g}=500 \mathrm{~km}$. $/ \mathrm{h}$. and $\phi=52^{\circ}, \tau$ must be less than $60^{\circ}$ in order to ensure an error of less than $6^{\prime}$ in the altitude observation.

(2) Loxodrome Curvature, - The radius of curvature of the loxodrome corresponding to a given course angle $\psi$ is given by

where

$$
r=R / \sqrt{ }\left(\mathrm{r}+\sin ^{2} \psi \tan ^{2} \phi\right)
$$

$$
\begin{aligned}
R & =\text { radius of earth }=6,370 \mathrm{~km} . \\
\phi & =\text { latitude. }
\end{aligned}
$$

Limiting ourselves as before to the horizontal component of the acceleration, the lateral deffection of the apparent vertical is given by

$$
\alpha_{\mathrm{F}}=\left(\frac{V_{\mathrm{g}}{ }^{2}}{R_{\mathrm{g}}}\right) \tan \phi \sin \psi
$$

producing an error in the altitude of a given star of the amount $\alpha_{p} \sin \tau$, where $\tau$ is the azimuth. Even under the most unfavourable conditions $\left(\psi=90^{\circ}\right) \alpha_{F}$ will be less than $4^{\prime}$ at speeds up to $800 \mathrm{~km}$. $/ \mathrm{h}$.

The loxodrome cuts all meridians at an angle equal to the course $\psi$.

If, however, the course is set by a magnetic compass, the actual path will deviate from a loxodrome due to changes in the magnetic declination. This will require an additional correction depending on the rate of change of the declination with length of flight path.

The error due to this effect is not likely to exceed $I^{\prime}$ for flights in our latitudes, provided the ground speed is less than $500 \mathrm{~km} . / \mathrm{h}$. and the rate of change of declination less than $1 \% \mathrm{r} 00 \mathrm{~km}$.

(3) Change IN Wind Velocity.-If the wind along the course changes in magnitude and direction, the aircraft will be accelerated relatively to the ground. Taken over a longer time interval, these accelerations will act in the same 
direction and will therefore not cancel out when taking mean values of the apparent vertical.

The apparent vertical will deflect in the opposite direction to the wind speed by an amount which depends on the ground speed as shown below.

$\begin{array}{cccc}\text { Change in Wind Speed } & & V_{\mathrm{g}}(\mathrm{km} . \mathrm{h} .) & \\ \text { per } 100 \mathrm{~km} \text {. flight path. } & 300 & 500 & 700 \\ \text { I km./h. } & .08^{\prime} & .13^{\prime} & .19^{\prime} \\ 20 \mathrm{~km} . / \mathrm{h} . & 1.6^{\prime} & 2.6^{\prime} & 3.7^{\prime}\end{array}$

Under normal conditions the effect is small. Its exact determination will require very accurate weather maps.

Summing up, it appears that averaging the apparent vertical will give results of sufficient accuracy only if the aircraft is flown under very steady conditions (change in ground speed less than $4 \mathrm{~km} . / \mathrm{h}$., course deviation less than $.4^{\circ}$ both taken over an interval of $I$ minute). This refers to accidental variations.

The constant errors only become important at high latitudes and speeds above $700 \mathrm{~km} . / \mathrm{h}$.

Determination of TNT Content of Air. (Z.G.S.S., Vol. 38, No. 2, Feb., I943, p. 32.) (I $14 / 3^{2}$ Germany.)

The atmosphere of TNT plants contains varying amounts of the chemical, both in the form of dust and vapour. This is injurious to the health of the workers and necessitates accurate control. The German Ministry of Production has issued particulars of a chemical process for the rapid and accurate determination of the amount of nitro-aromatics present in the air.

By means of a large aspirator, 50-100 litre of the air under test are passed through three test tubes in series, each containing 1o cc. of methanol. The internal diameters of the test tubes and connecting tubes are $17 \mathrm{~mm}$. and $5 \mathrm{~mm}$. respectively. The rate of flow is adjusted so that no bubbling over occurs and there is no undue loss of methanol by evaporation. Contents of tubes one and two (originally amounting to $26 \mathrm{cc}$.) are mixed and shaken up with $2 \mathrm{cc}$. of 2 per cent. caustic soda solution. After a rest period of ro minutes the resultant colouration is compared photometrically with a series of standards obtained by dissolving known amounts of TNT in $15 \mathrm{cc}$. of methanol similarly, treated with caustic soda. The matching must be carried out within 20 minutes of the soda addition, otherwise sedimentation produces error. It is stated that quantities as low as $.05 \mathrm{mg}$. TNT can be detected, corresponding to $.5 \mathrm{mg} . / \mathrm{m} .3$ if roo litres are passed.

The third test tube should shown no discolouration and thus acts as a check.

It is pointed out that the colour change is not specific to TNT but can also be used for dinitrotoluol and other nitroaromatics. That colour is a rough indication of the amount of TNT vapour in the air is provided by exposing filter paper previously soaked in a 5 per cent. alcoholic solution of $\mathrm{KOH}$ and subsequently dried in a clean atmosphere.

Under the influence of the TNT vapour the test paper is at first coloured pink and then turns. brown. The time required to produce a given standard tint is a rough indication of the concentration of the vapour.

Rate of Ice Formation. (A. L. London and R. A. Seban, A.S.M.E. Preprint, April 26-28, 1943.) (1 $14 / 33$ U.S.A.)

The problem of ice formation in liquids in contact with boundaries of various geometries has received but little attention in the literature. Perkeris and Slichter (J. Appl. Phys., Vol. 1o, 1939, pp. 135-137) derive an approximate solution for the rate of ice formation on the outside of a cylinder for liquid at the freezing point and infinite surface conductance at the inside cylinder surface. In this solution, the inside surface temperature may be any function of the time. Elmer (Refrig. Engg., Vol. 24, 1932, p. 17) derives a similar expres- 
sion for the rate of ice formation on submerged pipes. Other more exact solutions for slab-ice formation are available, but these are of considerable complexity and limited to a constant free-surface temperature. A new consideration of the problem in general with emphasis on approximate solutions of such form as to be readily applied to typical problems therefore seems appropriate.

The objectives of this paper are to accomplish the following :-

I. Describe a general approximate method of analyzing the problem of freezing in liquids bounded by surfaces of various geometries. "Freezing " is hereafter called "ice formation" but the generality of the method will be apparent.

2. Present solutions for the rate of ice formation for boundary geometries which are of significance in applications, i.e., cylinders, spheres, plane surfaces. These solutions are presented algebraically and graphically and are expressed in terms of dimensionless variables.

3. Estimate the degree of approximation of these solutions.

4. Illustrate the application of the approximate solutions by specific applications in ice manufacture and quick freezing of food products.

The results are stated to be in good agreement with practice.

Limits of Human Heat Regulation. (L. H. Newburgh, L. P. Herrington and A. P. Gagge, J. Aeron. Sci., Vol. Io, No. 6, June, 1943, pp. 197-199.) (1 $14 / 34$ U.S.A.)

The human organism is provided with a complicated mechanism which tends to keep the body temperature constant in spite of the varying production of internal heat or changes in the outside temperature.

Under comfortable conditions, the individual loses heat from the surface of. the body at the same rate it is produced internally. The external loss is due to radiation, conduction, convection and evaporation of water and will depend on the skin temperature as well as on the humidity and temperature of the surrounding air. When the skin temperature is equal to the air temperature, heat can only be lost by the evaporation of water (sweat) and this is severely restricted if the relative humidity is high (moist desert heat). Under such circumstances the balance is upset and physical work must be restricted to the utmost if fatal results are to be avoided. If, however, the relative humidity is not above 20 per cent. the usual non-combatant field duties can be carried out for eight hours daily at air temperature up to $125^{\circ} \mathrm{F}$. Under these conditions the individual loses about I litre of sweat per hour. $(\mathrm{NaCl}$ content $2 \mathrm{gm}$. per litre).

The extra-cellular fluid in the body (from which the sweat is derived) contains about $8 \mathrm{gm}$. of $\mathrm{NaCl}$ per litre of water and this salinity must be maintained over relatively close limits for proper functioning of the organism.

Heavy sweating thus not only reduces the total amount of extra-cellular fluid but also affects its composition. Under these conditions it is thus not only necessary to have adequate supplies of drinking water but additional salt must be administered.

Whilst sweating provides an effective method for preventing an undue rise in skin temperature, the corresponding protective mechanism against cold appears much less efficient. There appears to be no automatic increase in the internal heat production of the body to prevent progressive cooling. Shivering only provides a moderate relief and the individual is forced to undergo strenuous exercise combined with adequate clothing if the effect of cold is to be resisted.

In this connection it is important to note that even the warmest unheated flying clothing will not prevent a gradual drop in body temperature when exposed to temperatures below $30^{\circ} \mathrm{F}$. Extreme discomfort arises when the skin temperature falls from its normal value of $93^{\circ} \mathrm{F}$. to $80^{\circ} \mathrm{F}$. on the trunk and $40^{\circ} \mathrm{F}$. at the 
toes. At an ambient temperature of $30^{\circ} \mathrm{F}$. these dangerous limits are reached in $20 \mathrm{hrs}$. and $7 \mathrm{hrs}$. respectively, whilst at $-30^{\circ} \mathrm{F}$. the period is reduced to about 3 hrs.

On account of the cramped quarters in an aircraft, adequate remedial exercises are difficult and often impossible for certain members of the crew.

Although electrically heated clothing appears to form an ideal solution, most pilots have an inherent objection to this method (fear of burns?). In addition, it suffers from the drawback of constituting a heavy drain on the electric power supply.

A natural line of development appears to be an increase in the heat insulation of the clothing. This cannot be done by an increase in the thickness of the fabric already in use, since the clothing is already so heavy and bulky that it reduces agility and very markedly becomes a serious risk when effecting an emergency landing on water.

The authors are of the opinion, however, that it should be possible to develop a fabric of reduced thermal conductivity without increase in weight, and research in this direction is strongly, recommended.

American Lease Lend Report. (Inter. Avia., No. 869-870, 18/5/43, pp. 18-19.) (I $4 / 35$ U.S.A.)

The report covers the period II.3.4I to I.4.43.

The total aid given by the U.S.A. over this period to its allies amounted to $10.3 \times 10^{9}$ dollars, of which 82 per cent. represented goods (munitions, industrial supplies, food) whilst the remaining 18 per cent. covered services rendered (shipping, ship repairs, training, etc). Of the goods supplied, 55 per cent. have been munitions and 15 per cent. food. Nearly one-third of the munitions were represented by aircraft ( $1.4 \times 10^{9}$ dollars) over the first three months of this year, the shipment of lease-lend goods was apportioned as follows:-

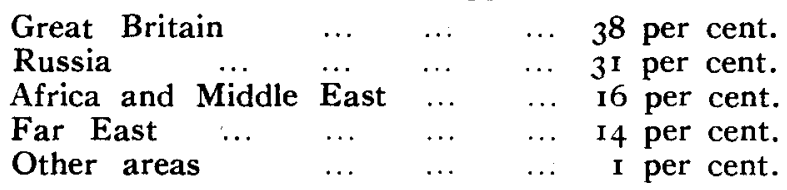

The total aid rendered over the period under consideration represents about 13 per cent. of the total war expenditure by the U.S.A. over the same period.

Lend-lease and direct purchase of combat aircraft by America's allies have accounted for about one-third of the total American production. 


\section{LIST OF SELECTED TRANSLATIONS.}

No. 60 .

NoTE.-Applications for the loan of copies of translations mentioned below should be addressed to the Secretary (R.T.P.3), Ministry of Aircraft Production, and not to the Royal Aeronautical Society. Copies will be loaned as far as availability of stocks permits. Suggestions concerning new translations will be considered in relation to general interest and facilities available.

Lists of selected translations have appeared in this publication since September, $193^{8 .}$

\section{Aero and Hydrodynamics.}

TRAN SLATION NUMBER

AND AUTHOR.

I8I9 Ackeret, J. ...

Pfenninger, $W$. Vandrey, F.

I832 Guderley, G.

1833

$-\cdots \quad \cdots$

I825. Kircheman, D.

I83o Busemann, A.

\section{TITLE AND REFERENCE.}

Prevention of Turbulent Boundary Layers of Suction. (Die Naturwissenschaften, Vol. 29, No. $4 \mathrm{I}, \mathrm{Io} / \mathrm{IO} / 4 \mathrm{I}, \mathrm{pp} .622-623$.)

The Influence of the Nozzle on Resistance Measurements in the Free Jet-II. (Z.A.M.M., Vol. 22, No. I, Feb., 1942, pp. 15-22.)

The Resistance Problem in High Speed Flights. (Schriften d. deutschen Akademie, L.F.F., No.

30, pp. 17-36.)
Regression Edges in Two-Dimensional Compressi. ble Potential Flow. (Z.A.M.M., Vol. 22, No. 2, June, 1942, pp. I21-1 26.)

Drag Reduction at High Speeds by Inducing Supersonic Vibrations on the Surface. (Flugsport, Vol. 34 , No. 23, I I $/$ I $/ 42$, pp. 165-166, Pat. No. 726,324.)

Atrcraft and ACCEssories.

1822 Hulten, N. ... ... Close-Up of the Lagg-3. (Flug cch Motor, Vol. 21, No. 6-7, March-April, I943, pp. 25-27 and 2I-24.)

${ }_{1823}$ Horten, G. ... ... The Horten IV All-Wing Glider. (Flugsport, Vol. 34 , No. 4, I8/2/42, pp. $5^{\mathrm{I}-55}$; and Flugsport, Vol. 34, No. 6, I7/3/42, pp. 63-67.)

${ }_{18.35}$ Junkers $\quad \ldots \quad \ldots$ Jettisoning Containers for Aircraft, in Particular Jettisoning Fuel Tanks. (Flugsport, Vol. 33, No. 25, I0/12/41, p. 76, Patent No. 713,321.)

1945 Focke-Wulf An Aircraft Wing with Slotted Flaps. (Flugsport, Vol. 34, No. 19, 16/9/42, p. I50, Patent No. 723,748 .)

I846 Fieseler ... ... Quick Release Device for Parts, in Particular Jettisoning Undercarriages-Dropped from Aircraft. (Flugsport, Vol. 34, No. 22, 22/10/42, p. I64, Patent No. 722,027.)

${ }_{1852}$ Henschel ... ... Multi-Engined Landplane with Buoyant Cabin. (Flugsport, Vol. 32, No. 26, 18/12/40, p. I57, Patent No. 699,351.) 
TRANSLATION NUMBER AND AUTHOR.

I859 Pintsch

1860 Heinkel, E. ...

I826 Theiner, J. ...

1827 Hansen, M.... Seeman, H. J.

I83 I Schmidt, R. . .

1829 Gorner, J. . .

I864 Schmidt, U.

$1820-\ldots$

1824 Schulze, W. M. N. Tropical Climates and Communication Technique.

I82I Buchner, $\mathrm{H}$. (Elek. Nachrichtentecknik, Vol. 18, No. 6, 1941, pp. 134-1 38.) (Translated by A.D.R.D.E.)

Mathematics.

TITLE AND REFERENCE.

Retractable Aircraft Searchlight. (Flugsport, Vol. $3^{2}$, No. 3, 31/1/40, p. 84, Patent No. 686,222.) Lifting Device for Loading Aircraft. (Flugsport, Vol. 34 , No. 26, 23/1 2/42, pp. 179-180, Patent No. 725,509 .)

Materials and Elasticity.

.. Strength Characteristics of Woods Used in Captured Russian Aircraft. (Luftwissen, Vol. Io, No. 4, April, 1943, pp. 103-104.)

... Investigations of Aluminium-Zinc Magnesium Wrought Alloyis-II. (Aluminium, Vol. 22, No. 9, 1940, pp. 442-458.)

.. The Bending Fatigue Strength of Machined Crankshafts After Straightening, with Notes on the Stress Distribution, Obtained by Extensometer and X-Ray Diffraction Measurements. (Luftwissen, Vol. 9, No. 9, Sept., 1942, pp. 263-267.)

IN STRUMENTS.

High Speed Electro-Magnetic Revolution Counter. (E.T.Z., Vol. 63 , No. 35-36, 10/9/42, p. 416.)

... A Fully Automatic Fuel Flow Meter. (A.T.Z., Vol. 45, No. 24, Dec., I942, pp. 670-672.)

Wireless and Electricity.

.. Calculation of the Process Responsible for the Excitation of Oscillations on a Valve Connected to a Barkhausen-Kurz Circuit. (Archiv f. Elekt., Vol. 26, 1932, pp. 84T-849.)

An Approximate Solution of the Ordinary Linear Differential Equation of the First Order. (Z.A.M.M., Vol. 22, No. 3, June, 1942, pp. 143-I 52.) 
TITLES AND REFERENCES OF ARTICLES AND PAPERS SELECTED FROM PUBLICATIONS REVIEWED IN R.T.P.3.

Requests for further information or translations should be addressed to R.T.P.3, Ministry of Aircraft Production.

\begin{tabular}{rlllllr}
\multicolumn{8}{c}{ Index. } \\
I. & Theory and Practice of Warfare & $\ldots$ & $\ldots$ & Items. \\
II. 98 \\
III.
\end{tabular}

\section{THEORY AND PRACTICE OF WARFARE.} General Strategy and Tactics.

\footnotetext{
ITEM R.T.P.

No. REF. $\quad$ TITLE AND JOURNAL.

I 10873 G.B. ... ... The Burman Battle. (N. Macmillan, Aeronautics,

Vol. 8, No. 4, May, 1942, pp. 28-3I.)

210908 Germany ... German Opinions on Aerial Warfare Code Applied to Paratroops and General Use of Parachutes. (Inter. Avia., No. $859-860,6 / 3 / 43$, pp. 1-5.)

310946 G.B. ... ... Mine Sweeper Aircraft (Explodes Magnetic Mines). (Inter. Avia., No. $861,17 / 3 / 43$, p. 8.)

4 ro97 I G.B. ... ... Air Force Targets in Sardinia. (Engineer, Vol.

4 I 45 , No. $4,560,4 / 6 / 43$, pp. $443-445$.

5 to973 G.B. ... ... Defence of Ships Against Torpedo Attack. (Engineer, Vol. I 75 , No. $4,560,4 / 6 / 43$, p. 448 .)

$6 \quad 17755$ Germany ... The, Attacks on the Mohne and Eder Damms (Inter. Avia., No. $869-870$, $18 / 5 / 43$, pp. 22-23.)

Organisation and Training.

7 ro654 G.B. ... ... Night Flying Training. (Flight, Vol. 43, No. I,786, $27 / 5 / 43$, pp. 552-553.)

496
} 
ITEM R.T.P.

No. REF.

8 ro67 I France

$9 \quad 10728$ India

I0 10740 G.B. ...

I I 10741 G.B. ...

$12 \quad 10742$ G.B. ...

I4 I0745 G.B. ...

I5 I0746 G.B. ...

16 I0786 G.B. ..

I7 10789 France

I8 10855 U.S.A.

19 I0875 G.B. ...

2 I 10957 G.B. ...

23 rog92 U.S.A.

$24 \quad 11483$ Italy ...
1310743 G.B. ...

$20 \quad 10955$ U.S.A.

2210990 U.S.A.

TITLE AND JOURNAL.

Fighting French Air Transport. (Aeroplane, Vol. 64 , No. 1,668, 14/5/43, p. 574.)

The Indian Air Force. (Aeroplane, Vol. 64, No. 1,662, 2/4/43, p. $3^{84}$.)

R.A.F. Silver Jubilee. (Aeroplane, Vol. 64, No. $1,662,2 / 4 / 43$, pp. $3^{85-386 .)}$

Genesis of the R.A.F. (C. G. Grey, Aeroplane, Vol. 64 , No. $1,662,2 / 4 / 43$, p. 387.$)$

R.A.F. Squadrons-1918. (Aeroplane, Vol. 64, No. $1,662,2 / 4 / 43$, p. 388 .)

The R.A.F. in the Years Between Two Wars. (J. M. Spaight, Aeroplane, Vol. 64, No. I,662, $2 / 4 / 43$, p. $3^{89}$.)

... R.A.F. in the Test of Wars. (Aeroplane, Vol. 64, No. $1,662,2 / 4 / 43$, pp. 392-394.)

... Twenty-Five Years of Progress in the R.A.F. (P. Masefield, Aeroplane, Vol. 64, No. 1,662, 2/4/43, pp. 394-396.)

Aircraft $v$. Submarines. (Aeroplane, Vol. 64, No. I $, 666,30 / 4 / 43$, pp. 49I-492.)

French Airmen in Russia. (Aeroplane, Vol. 64, No. I ,666, 30/4/43, p. 495.)

Training of Naval Fire-Fighters. (A. D. Rathbone, Sci. Am., Vol. 168, No. 4, April, 1943, pR. I50-153.)

Natural Formations. (A. Falorde, Aeronautics, Vol. 8, No. 4, May, 1942, pp. 36-39.)

U.S.A. New Naval Aircraft Type Designations. (Inter. Avia., No. $861,17 / 3 / 43$, p. I4.)

R.A.F. Air Transport Command. (Inter. Avia., No. $861,17 / 3 / 43$, p. 17.)

Popular Names of U.S. Military Aircraft. (Autom. Ind., Vol. 88, No. 6, r 5/3/43, pp. 98-99.)

World Military Aeroplanes Grouped by Types. (Autom. Ind., Vol. 88, No. 6, I5/3/43, pp. 105-109.)

Italian Advisory Air Committee. (Inter. Avia., No. 867, I/5/43, pp. 29-30.)

\section{Design and Equipment.}

2510628 G.B. ... _.. Parachute Supply Container Dropped by R.A.F. in Jugoslavia (Photograph). (Flight, Vol. 43, No. I,794, 13/5/43, p. 490.)

26 10632 Germany ... Pneumatic Dinghy Used by the Luftwaffe (Photo). (Flight, Vol. 43 , No. I,795, r3/5/43, p. 500.)

$27 \quad 10737$ G.B. ... ... Enemy Parachute Ammunition Container (Photograph). (Aeroplane, Vol. 64, No. 1,662, 2/4/43, p. $3^{82 .)}$

281087 I U.S.A. … Asbestos Fittings for Use in Aircraft. (Sci. Am., Vol. 168, No. 4, April, 1943, p. 185.) 
ITEM R.T.P.

$29 \quad 10874$ G.B.

$30 \quad$ Iog5I France

$3^{\text {I }} \quad 10969$ G.B. ..

$32 \quad$ 1 1056 U.S.A.

$33 \quad$ I 1088 Germany

34 Iri42 Germany

$35 \quad 11185$ U.S.A.

$36 \quad$ II199 Germany

37 II 201 Germany

$38 \quad 11208$ Germany

$39 \quad 11245$ U.S.A.

$40 \quad$ I1308 Germany

$41 \quad$ I 377 G.B. ...

42 I1 390 U.S.A.

$43 \quad 11405$ U.S.A.

$44 \quad \mathrm{I} 45^{\circ}$ U.S.A.

$45 \quad 11459$ U.S.A.

$46 \quad$ I 4880 Italy $\ldots$

$47 \quad 10640$ G.B. ...
TITLE AND JOURNAL.

Armoured Aviation. (Aeronautics, Vol. 8, No. 4, May, 1942, pp. 33-35.)

Moram Fighter Trainer Uses Plymex Method of Construction (Wood Veneers Bonded to Al. Sheet). (Inter. Avia., No. 86r, 17/3/43, po 12.) A Lifeboat Dropped by Parachute. (Engineer, Vol. I 75, No. $4,560,4 / 6 / 43$, p. 439.)

Glass-Insulated Portable Shelter for Army Use in the Arctic. (Sci. Am., Vol. I68, No. 5, May, 1943, p. 222:)

The High Performance Fighter. (K. Tank, Luftwissen, Vol. 10, No. 4, April, 1943, pp. 99-102.)

Parachute Descent and Time Reserve at Great Heights. (Gauer and others, Luftfahrtmedizin, Vol. 6, No. I-4, 23/4/42, p. 340.)

Variable Intensity Pilot Light. (Autom. Ind., Vol. 88 , No. $7,1 / 4 / 43$, p. 43 .)

Jettisonable Container for Flares and Other Inflammable. Materials. (Pat. series No. 3, 730,495.) (Arado, Flugsport, Vol. 35, No. 8, $21 / 4 / 43$, p. 18.)

Retractable Support for Jettisoning Loads for Aircraft. (Pat. series No. 3, 730,654.) (Junkers, Flugsport, Vol. 35, No. $8,21 / 4 / 43$, p. 18.)

Stowage for Jettisonable Load8. (Pat. series No. 3, 73I,05I.) (Sageb, Flugsport, Vol. 35, No. 8, $2 \mathrm{I} / 4 / 43$, p. 19.)

Fire Fighting Equipment on Pan-American Clipper. (Sci. Am., Vol. 168, No. 6, June, 1943, p. 259.)

Light Aircraft Fitted with Gas Generator. (Flugsport, Vol. 35, No. 10, 16/6/43, pp. I26-1 27.)

The Duff Norton Aeroplane Jack. (Airc. Eng., Vol. 15, No. 172, June, 1943, pp. 183-184.)

Improved Aircraft Life Rafts (Wright Field Equipment). (Aviation, Vol. 42, No. 3, March, 1943, pp. 26I and 370.)

Field Maintenance and Repair of Fighting Aircraft (Digest). (N. R. Kearney, J.S.A.E., Vol. 5I, No. 5, May, 1943, p. 32.)

Fore Part of the Boeing B-1 $7 F$ Dorsal Fin (Drawing). (Aviation, Vol. 42, No. 4, April, 1943, p. 183.$)$

Aircraft Maintenance Equipment (Hydraulic Jack for Tyre Removal, Portable Engine Test Stand, etc.). (Aviation, Vol. 42, No. 4, April, 1943, pp. 223-225.)

Italian Air Force Equipment. (Inter. Avia., No. 867, I/5/43, pp. 21-22.)

\section{Armament.}

G.B. ... ... Air Gunnery Training. (Aeroplane, Vol. 64, No. I,670, 28/5/43, pp. 628-629.) 


\begin{tabular}{rrr} 
ITEM & \multicolumn{2}{c}{ R.T.P. } \\
NO. & REF. \\
48 & 11810 & Germany \\
& & \\
49 & 10884 & U.S.A. \\
50 & 11093 & Germany \\
& & \\
51 & 11094 & Germany \\
& & \\
52 & 11180 & U.S.A.
\end{tabular}

53 I1204 Germany

$54 \quad 1$ II 4 Germany

5511315 Germany

$56 \quad 11453$ G.B. ...

$57 \quad 11460$ U.S.A.

$58 \quad 11465$ U.S.A.

$59 \simeq 1467$ G.B. ...
TITLE AND JOURNAL.

German Report of New R.A.F. Explosive Incendiaries. (Flight, Vol. 43, No. $1,793,6 / 5 / 43, P$. 480.)

Armament of Flying Fortress (Booing B-I $E$ and F). (Inter. Avia., No. $858,26 / 2 / 43$, pp. 7-8.)

$A$ Sound Proof Shooting Range. (W. Pfeiffer, Luftwissen, Vol. ıo, No. 4, April, I943, p. I 18.)

Research on Bombs. (G. Madelung, Luftwissen, Vol. 1o, No. 4, April, 1943, p. 1 23.)

Boulton Paul Gun Turret Mechanism. (M. W. Bourdon, Autom. Ind., Vol. 88, No. 7, I/4/43, pp. 28-33.)

Bomb Stowage. (Pat. series No. 3, 731, о5०.) (Henschel, Flugsport; Vol. 35, No. 8, $21 / 4 / 43$,

pp. 18-19.) 5, 732,734.) (Henschel, Flugsport, Vol. 35, No. 10, $16 / 6 / 43$, p. 29.)

Gun Mounting in Front of Propeller and Supported on $H u b$. (Pat. series No, 5, 733,329.) (Junkers, Flugsport, Vol. 35, No. 10, 16/6/43, p. 29.)

The Bristol Hydraulically-Operated Power-Driven Gun Turret (Drawing). (Aviation, Vol. 42, No. 4. April, 1943, p. 187.)

Designing Gun Turrets as Integral Part of Aircraft. (L. G. Frise, Aviation, Vol. 42, No. 4, April, 1943, pp. 227-231.)

Martin Gun Interrupter on U.S. Combat Planes. (Aviation, Vol. 42, No. 4, April, 1943, p. 307.)

New British Delayed-Action Bomb with Dual Mechanism. (Aviation, Vol. 42, No. 4, April, 1943, p. 31 1.)

\section{Military Types of Aircraft (British and Japanese).}

$60 \quad 10615$ G.B. and

U.S.A. ... craft Production, Vol. 5, No. 56, June, I943,

61 10618 G.B. ... p. 302.)

Avro Lancaster II. (Flight, Vol. 43, No. I,795, 20/5/43, p. 520.)

6210619 G.B. ...

The Fairey Albacore (Photograph). (Flight, Vol. 43 , No. $1,795,20 / 5 / 43$, p. $5^{20}$.)

6310624 Japan

6410626 G.B. ...

Mitsubishi S-OO (Recog. Deitails). (Flight, Vol. 43, No. $1,795,20 / 5 / 43$, p. b.)

Hurricane on Catapult Mounting (Photograph). (Flight, Vol. 43, No. 1,795, 20/5/43, p. 537.)

$6_{5} 106_{3} 1$ G.B. ... Hawker's Latest Fighter-The Typhoon $(2,400$ h.p. Napier Sabre). (Flight, Vol. 43, No. I,794, 13/5/43, pp. 496-498.)

$66 \quad 10642$ Japan

Mitsubishi Navy SHS-OO Single-Seat Fighter Float Planes (Photograph). (Aeroplane, Vol. 64, No. $1,669,21 / 5 / 43$, p. $5^{83}$.)

67 I0643 G.B. ... ... Supermarine Spitfire IX (Photograph). (Aeroplane, Vol. 64 , No. I,669, $21 / 5 / 43$, p. $5^{82}$.) 
ITEM R.T.P.

NO. REF.

6810645 G.B. ..

6910653 G.B. ...

$70 \quad$ I066I G.B. ...

7 I 10668 G.B. ...

7210669 G.B. ...

73 10670 G.B. ...

74 I0736 Japan

$75 \quad 10744$ G.B. ...

$76 \quad 10748$ G.B. ..

77 I0749 G.B. ...

$78 \quad 10754$ G.B. .

$79 \quad 10755$ G.B. ...

8o 10756 G.B. ...

8I $1079^{2}$ G.B. ...

$82 \quad 10796$ G.B. ...

$83 \quad$ I0797 G.B. ...

8410799 G.B. ...

*85 10802 G.B. ...

8610803 G.B. ..

87 I0804 G.B. ...
TITLE AND JOURNAL.

A Fighting Mosquito Squadron. (Aeroplane, Vol. 64 , No. 1,669, $21 / 5 / 43$, pp. 588-589.)

The Airspeed Oxford Trainer. (Flight, Vol. 43, No. $1,786,27 / 5 / 43$, pp. 549-55 I.)

Supermarine Spitfire V.B.'s Flying Over Australian Mainland (Photograph). (Aeroplane, Vol. 64, No. $1,668,14 / 5 / 43$, p. 550.)

The Typhoon, its History and Development: The Sopwith Types, 1914-1918; Earlier Hawker Types, 1923-1929; The Furies, 1933-1936; Hurricane to Typhoon, r935-r943. (Aeroplane, Vol. 64 , No. 1,668, r 4/5/43, pp. 559-566.)

The Hawker Typhoon I.B. (Napier Sabre Engine). (Aeroplane; Vol. 64, No. 'I,668, 14/5/43, pp. 542-543.)

he Fairey Swordfish-its Work in Naval Operations. (Aeroplane, Vol. 64, No. I,668, 14/5/43, pp. 572-573.)

Wreclage of a Mitsubishi SSH-OO Float Plane Fighter (Photo). (Aeroplane, Vol. 64, No. 1,662, 2/4/43, p. 382.)

Some Notable Aeroplanes of the R.A.F., 1918-1943 (Photographs). (Aeroplane, Vol. 64, No. 1,662, 2/4/43, pp. 390-391.)

Pilot's Cockpit of De Havilland Mosquito Bomber (Photograph). (Aeroplane, Vol. 64, No. I,667, $7 / 5 / 43$, p. $5^{23}$.)

Supermarine Spitfire VB (Photo). (Aeroplane, Vol. 64 , No. I,667, 7/5/43, p. 525.)

De Havilland Mosquito (I-IV). (Aeroplane, Vol. 64 , No. $\mathrm{x}, 667,7 / 5 / 43$, pp. 532a-539.)

The Bristol Blenheim V.P. Light Bomber (Recognition Details). (Aeroplane, Vol. 64, No. I,667, 7/5/43, pp. 544-545.)

Martin Marauder I (Recognition Details). (Aeroplane, Vol. 64 , No. I $667,7 / 5 / 43$, pp. 544-545.)

Fairey Albacores with Folded Wings on Flight Deck of Aircraft Carrier "Indomitable" (Photograph). (Aeroplane, Vol. 64, No. I ,666, 3o/4/43, p. 498.)

$\therefore$ The Hawker Typhoon (Photo). (Aeroplane, Vol. 64 , No. I,666, 30/4/43, pp. 504-505.)

Hurricane i $D$ (Photograph). (Aeroplane, Vol. 64, No. I,666, 3o/4/43, pp. 504-505.)

The Hawker Typhoon. (Aeroplane, Vol. 64, No. I,666, 3\%/4/43, pp. 513-515.)

An Airspeed Horsa Military Glider (Photo). (Aeroplane, Vol. 64, No. I $662,2 / 4 / 43$, p. 379.)

Hawker Typhoon (Recognition Details). (Flight, Vol. 43 , No. $1,793,6 / 5 / 43$, p. 466.$)$

The Mosquito (from Design Stage to Operational Service). (Flight, Vol. 43, No. I,793, 6/5/43, pp. $467-47^{2}$.)

* See also Glider Section (Items 187-193). 


\begin{tabular}{ccc} 
ITEM & \multicolumn{2}{c}{ B.T.P } \\
No. & \multicolumn{2}{c}{ REF. } \\
88 & 10805 & G.B. $\ldots$ \\
89 & 10888 & G.B. $\ldots$ \\
90 & 10889 & G.B. $\ldots$ \\
91 & 10890 & G.B. $\ldots$ \\
92 & 10896 & G.B. $\ldots$ \\
93 & 10921 & Japan \\
94 & 10935 & G.B. $\ldots$ \\
95 & 10936 & G.B. $\ldots$ \\
96 & 10743 & G.B. $\ldots$
\end{tabular}

9710945 G.B. ...
TITLE AND JOURNAL.

... De Havilland Mosquito F.1 1 Fighter. (Flight, Vol. 43 , No. $r, 793,6 / 5 / 43$, pp. A-B.)

... Blenheim (Bisley) Close Support Bomber. (Inter. Avia., No. $858,26 / 2 / 42$, pp. I and ro.)

... Lancaster $I$ and $I I$. (Inter. Avia., No. 858, 26/2/43, pp. IO-I I.)

Anson $V$ and VI (Vidal Plastic). (Inter. Avia., No. $858,26 / 2 / 43$, pp. I 4 and 15 .)

... Lancaster Bomber Converted to Transport (Yorti), (Inter. Avia., No. $858,26 / 2 / 43$, p. I6.)

Mitsubishi S.OO Fighter. (Inter. Avia., No. $856-857$, I $5 / 2 / 43$, p. Io.)

De Havilland "Mosquito." (Inter. Avia., No. 856-857, I 5/2/43, pp. I I and I8.)

Miles $M .28$ Trainer and Liaison Plane. (Inter. Avia., No. $856-857,15 / 2 / 43$, pp. I and 18 .)

Westland Whirlwind Converted into a Fighter Bomber (Whirlibomber). (Inter. Avia., No. 86r, $17 / 3 / 43$, p. 7.$)$

Fairey Barracuda Torpedo and Dive Bomber. (Inter. Avia., No. $86 \mathrm{r}, 17 / 3 / 43$, p. 7.)

\section{Military Types of Aircraft (U.S.A.).}

9810620 U.S.A.

... Republic Thunderbolts (P.47). (Flight, Vol. 43, No. $1,795,20 / 5 / 43$, p. 520 .)

9910629 U.S.A.

100 10630 U.S.A.

IоI 10636 U.S.A.

$102 \quad 10637$ U.S.A.

Iо3 10638 U.S.A.

104 ro64I U.S.A.

10510646 U.S.A.

10610647 U.S.A.

10710649 U.S.A.

108 10655 U.S.A.

10910656 U.S.A.

I 10 10660 U.S.A.

II I 10662 U.S.A.

11210665 U.S.A.
U.S. Navy and Marine Wildcats (Photograph). (Flight, Vol. 43, No. I ,794, I3/5/43, p. 49r.)

Douglas Skymaster (C-54) Transport (Photo). (Flight, Vol. 43, No. I,794, 13/5/43, p. 491.)

Grumman Goose I (Recognition Details). (Flight, Vol. 43 , No. $1,794,13 / 5 / 43$, p. a.)

Chance-Vought Corsair Single-Seat Fighter (Photo). (Aeroplane, Vol. 64, No. I,670, 28/5/43, p. 61 2.) Sikorsky Helicopter (Photo). (Aeroplane, Vol. 64, No. I,670, 28/5/43, p. 612.)

The Seameu (Curtiss $\mathrm{SO}_{3} \mathrm{C}-\mathrm{I}$ ) (Photograph). (Aeroplane, Vol. 64, No. 1,669, 21/5/43, p. 581.) American Aeroplanes in Service-XIII (Silhouettes). (Aeroplane, Vol. 64, No. r,669, $21 / 5 / 43$, p. 590 .)

The Thunderbolt (Recognition Details). (Aeroplane, Vol. 64, No. 1,669, 21/5/43, pp. 591-592.)

The Beechcraft D-I $R$ (Recognition Details). (Aeroplane, Vol. 64, No. 1,669, $21 / 5 / 43$, p. 6o1.) Fairchild Cornell (Recognition Details). (Flight, Vol. 43 , No. I, $786,27 / 5 / 43$, p. a.)

Aeronca $L-58 B$ Deferder. (Flight, Vol. 43, No. I, $786,27 / 5 / 43$, p. b.)

Republic $P-47$ Thunderbolt (Photograph). (Aeroplane, Vol. 64 , No. $1,668,14 / 5 / 43$, p. 550 .)

Photograph of North American Mitchells Taking Off to Raid Tokio. (Aeroplane, Vol. 64, No. I,668, I $4 / 5 / 43 ;$ p. 55I.)

Vultee Vengeance (Photograph). (Aeroplane, Vol. 64 , No. 1,668, 14/5/43, p. 553.) 
ITEM

No.

I 310666 U.S.A.

I $141075^{\circ}$ U.S.A.

115 1075I U.S.A.

I 610753 U.S.A.

I17 10788 U.S.A.

118 10793 U.S.A.

11910807 U.S.A.

12010847 U.S.A.

I 2 I 10868 U.S.A.

12210876 U.S.A.

I 3 I0877 U.S.A.

124 I0880 U.S.A.

125 I0882 U.S.A.

$126 \quad 10883$ U.S.A.

$127 \quad 10885$ U.S.A.

I28 10886 U.S.A.

12910909 U.S.A.

$130 \quad 10910$ U.S.A.

I3I IOgII U.S.A.

$13^{2}$ Iog12 U.S.A.

133 logi 4 U.S.A.

$134 \quad \log 15$ U.S.A.

13510916 U.S.A.

$1^{6} \quad \log _{7}$ U.S.A.

$137 \quad 10924$ U.S.A.

${ }_{138}{ }^{8}{ }^{\circ} 25$ U.S.A.
TITLE AND JOURNAL.

Martin Mariner (Photograph). (Aeroplane, Vol. 64 , No. I,668, 14/5/43, p. 554.)

North American Mitchells (Photo). (Aeroplane, Vol. 64 , No. $1,667,7 / 5 / 43$, p. 528.)

Fuselage of Curtiss Warhawk Stowed Inside Cabin of Douglas C-47 Skytrain (Photo). (Aeroplane, Vol. 64 , No. $1,667,7 / 5 / 43$, p. 528.)

American Aeroplanes in Service-XII (Silhouettes). (Aeroplane, Vol. 64, No. $1,667,7 / 5 / 43$, p. 532.)

Noorduyn Norseman UC-64 (Photo). (Aeroplane, Vol. 64 , No. I $666,3 \% / 4 / 43$, p. 495.)

Douglas A-2oC Havoc Bombers Boston IIIe (Photograph). (Aeroplane, Vol. 64, No. I,666, 30/4/43, p. 498.)

The Lockheed-Vega Ventura. (Flight, Vol. 43, No. $1,793,6 / 5 / 43$, p. 478 .)

Fairchild Cornell Trainers (Photographs). (Pegasus, Vol. I, No. 2, Feb., 1943, pp. I I-I 2.)

The Lockheed Constellation. (Sci. Am., Vol. I68, No. 4, April, 1943, pp. 182-183.)

Lockheed "Constellation" (C-69). (Aeronautics, Vol. 8, No. 4, May, 1942, pp. 40-4I.)

Curtiss Caravan (C-76) (Photograph). (Aeronautics, Vol. 8, No. 4, May, 1942, pp. 40-41.)

Vought-Sikorsky V.S. 300. (Aeronautics, Vol. 8, No. 4, May, 1942, pp. 64-65.)

Curtiss Wright Caravan (C-76). (Inter. Avia., No. $858,26 / 2 / 43$, pp. I and 7.$)$

Lockheed C-69 Constellation. (Inter. Avia., No. $858,26 / 2 / 43$, p. 7.)

Curtiss $\mathrm{SO}_{3} \mathrm{C}-\mathrm{I}$ Scout "Seagull." (Inter. Avia., No. $858,26 / 2 / 43$, p. 8.)

Piper H.E.-I Ambulance Plane. (Inter. Avia., No. $858,26 / 2 / 43$, pp. I and 8.)

Brewster Bermuda Dive Bomber. (Inter. Avia., No. $859-860,6 / 3 / 43$, p. 8.)

Manta Long Range Fighter. (Inter. Avia., No. $859-860,6 / 3 / 43$, p. 7.$)$

Grumman Avenger Torpedo Plane (Photo). (Inter. Avia., No. 859-860, 6/3/43, p. 1.)

Curtiss "Seagull" Scout (Photo). (Inter. Avia., No. $859-860,6 / 3 / 43$, p. I.)

Curtiss C-76 Caravan. (Inter. Avia., No. 859-860, $6 / 3 / 43$, pp. I and $7-8$.)

Martin P.B. M-3 Mariner Patrol Bomber (Photo). (Inter. Avia., No. $859-860,6 / 3 / 43$, p. I.)

Fairchild $A T$-I 4 Trainer. (Inter. Avia., No. $859-860,6 / 3 / 43$, pp. I and 8-9.)

Vultee A-31 Dive Bomber (Georgia or Vengeance). (Inter. Avia., No. $859-860,6 / 3 / 43$, pp. I and 9.)

Vought Sikorsky Single-Seat Naval Fighter $\mathrm{F}_{4} \mathrm{U}_{-\mathrm{I}}$ "Corsair." (Inter. Avia., No. 856-857, 15/2/43, p. II.)

Republic $P_{-47}$ Thunderbolt High Level Fighter. (Inter. Avia., No. $856-857,15 / 2 / 43$, p. I 1.) 
TITLES AND REFERENCES OF ARTICles AND PAPERs.

ITEM R.T.P.

No. REF.

I $39 \quad 10926$ U.S.A.

$140 \quad 10927$ U.S.A.

14210929 U.S.A.

$1431093^{\circ}$ U.S.A.

$144 \quad 1093$ I U.S.A.

$1451093^{2}$ U.S.A.

$146 \quad 10934$ U.S.A.

148 Iog4I U.S.A.

I49 Iog42 U.S.A.

I5I 10954 U.S.A.

I52 10998 U.S.A.

15310999 U.S.A.

I 54 I I I 77 G.B. ...

155. I1246 U.S.A.

I $5^{6}$ I 1309 U.S.A.

$157 \quad 11469$ G.B. ..
141 I0928 U.S.A.

147 Iog40 U.S.A.

I5० 10944 U.S.A.

TITLE AND JOURNAL.

.. Lockheed P.38-E Lightning. (Inter. Avia., No. $856-857,15 / 2 / 43$, pp. I I-I 2.)

North American P-5I "Mustang." (Inter. Avia., No. $856-857$, I $5 / 2 / 43$, p. I 2 .)

North American B-25 Mitchell Medium Bombes (Inter. Avia., No. $856-857$, I 5/2/43, p. I 2.)

Curtiss Helldiver S.B. $2 C-\mathbf{I}$. (Inter. Avia., No. $856-857$, I $5 / 2 / 43$, p. I 2.)

Douglas Dive Bombers. (Inter. Avia., No. 856-857, $15 / 2 / 43$, p. I3.)

.. Cessna C-78 Liaison. (Inter. Avia., No. 856-857, $\mathrm{r} 5 / 2 / 43$, pp. I and I3.)

Grumman Avenger Torpedo Bomber. (Inter. Avia., No. $856-857$, I $5 / 2 / 43,-$ p. I 3.$)$

Piper Cub Liaison Plane. (Inter. Avia., No. $\mathbf{8 5}_{5} 6-857, I_{5} / 2 / 43$, pp. I I and I7.)

Lockheed L-49 Constellation (Photo). (Inter. Avia., No. $856-857$, I $5 / 2 / 43$, p. I.)

Fairchild AT-13 Trainer (Photo). (Inter. Avia., No. $856-857$, I $5 / 2 / 43$, p. I i.)

Boeing AT-15 Trainer (Photo). (Inter. Avia., No. $856-857$, I $5 / 2 / 43$, p. I I.)

Brewster $S B 2 A-2$ Navy Dive Bomber (Photograph). (Inter. Avia., No. 86 I, I7/3/43, p. I.)

Iockheed C-69 Constellation Transport. (Inter. Avia., No. $861,17 / 3 / 43$, pp. I and I $3-14$.

The Vega PV-I Patrol Plane (Photograph). (Autom. Ind., Vol. 88, No. 6, I 5/3/43, p. I34.)

The Goodyear FG-I Single-Seater Fighter (Photograph). (Autom. Ind., Vol. 88, No. 6, I 5/3/43, p. I34.)

The Halifax Four-Engined Bomber. (Engineer, Vol. 175, No. 4,562, I8/6/43, p. 490.)

Sikorsky Helicopter (Latest Type). (Sci. Am., Vol. I 68, No. 6, June, I943, p. 275.)

Republic P.47 Thunderbolt. (Flugsport, Vol. 35, No. Io, I6/6/43, pp. I 27-1 28.)

Auro Anson Mark V. (Aviation, Vol. 42, No. 4, April 23, p. 3I.3.)

\section{Military Types of Aircraft (U.S.S.R.).}

${ }_{15} 8 \quad 10623$ U.S.S.R. ‥ Stormovik $\mathrm{Il}_{-2} \mathrm{C}$ (Recognition Details). (Flight, Vol. 43 , No. $I, 795,20 / 5 / 43$, p. a.)

15910948 U.S.S.R. .. Russian Fighter Types I-18, I-20, I-26. (Inter. Avia., No. 86 r, 17/3/43, pp. I and 10.)

$160 \quad 11095$ U.S.S.R. ... A Close-up of the LAGG-3 Russian Fighter. (A. Hulten, Flyg och Motor, Vol. 2, No. 6-7, MarchApril, 1943, pp. 25-27 and 21-24.)

\section{Military Types of Aircraft (Sweden).}

161 10891 Sweden
... Swedish Dive Bomber B-1 7 with Retractable Snow Skids. (Inter. Avia., No. $858,26 / 2 / 43$, pp. I and 18.) 
ITEM

No.

6

162 Io644 Germany

I63 Io664 Germany

I64 Io752 Germany

I65 Io88I Germany

166

I67 10893 Germany

168 Io894 Germany

16ㅁ 10895 Germany

I70 10939 Germany

I7 10949 Germany

I72 II I8I Germany

I73 II182 Germany

$174 \quad 10622$ Italy ...

$175 \quad 10667$ Italy $\ldots$

I76 I079I Italy ...

$177 \quad 10739$ France

$\begin{array}{ccc}178 & 10913 & \text { France } \\ 179 & 10920 & \text { France } \\ 180 & 1095^{\circ} & \text { France } \\ 181 & 1095^{2} & \text { France } \\ 182 & 10953 & \text { France }\end{array}$

TITLE AND JOURNAL.

\section{Military Types of Aircraft (Germany).}

... Arado Ar 68E as a Fighter Trainer (Photo). (Aeroplane, Vol. 64 , No. I, $669,21 / 5 / 43$, p. 587 .)

.. Heinkel $\mathrm{He}$. I I $\mathrm{H}_{3}$ with Bomb Slung Externally Under the Centre Section (Photograph). (Aeroplane, Vol. 64, No. 1,668, 14/5/43, p. 553.)

Bucker Bestmann Two-Seat Cabin Monoplanes. (Aeroplane, Vol. 64, No. $1,667,7 / 5 / 43$, p. 531.)

Two German Six-Engined Aircraft (Me. 323 and Blohm and Vos8 222). (Aeronautics, Vol. 8, No. 4, May, 1942, p. 87.)

Messerschmitt Me. 109 G-2 High Altitude Fighter. (Inter. Avia., No. $858,26 / 2 / 43$, p. I 5.)

Messerschmitt Me. 210 Long Range Fighter. (Inter. Avia., No. $858,26 / 2 / 43$, pp. 15-16.)

Henschell Hs. I29 (Ground Attack Fighter). (Inter. Avia., No. $858,26 / 2 / 43$, p. I6.)

Junkers Ju. $87 D$ Dive Bomber. (Inter. Avia., No. $858,26 / 2 / 43$, p. 16.)

Junkers Ju. goS Four-Engined Transport (Photo). (Inter. Avia., No. $856-857$, I 5/2/43, p. 1.)

Arado Ar. 96, Built by S.I.P.A. (Inter. Avia., No. $861,17 / 3 / 43$, p. Io.)

Germany's Newest Fighter Bomber, Messerschmitt 2 Io A-I. (M. W. Bourdon, Autom. Ind., Vol. 88 , No. $7,1 / 4 / 43$, pp. 34-37.)

German Warplanes (Me. Io9 G-2, He. 1.29 and Ju. 87-D-I). (Autom. Ind., Vol. 88, No. 7, $1 / 4 / 43$, p. 37.)

\section{Military Types of Aircraft (Italy).}

... The Macchi C-202 Single-Seater Fighter (Photograph). (Flight, Vol. 43, No. I,795, 20/5/43, p. 526.)

.. Savoia-Marchetti SM79 Sparviero Carrying Torpedo (Photograph). (Aeroplane, Vol. 64, No. I,668, I $4 / 5 / 43$, p. 556.)

.. Cant Z 506 B Airone on Air-Sea Rescue Operations (Photograph). (Aeroplane, Vol. 64, No. I,666, 3o/4/43, p. 499.)

\section{Military Types of Aircraft (France).}

... Three French Flying Boats Reported Seized by the Germans. (Aeroplane, Vol. 64, No. I,662, $2 / 4 / 43$, p. 384 .)

.. Large French Flying Boat (Trials). (Inter. Avia., No. $859-860,6 / 3 / 43$, p. 21 .)

Bloch 157 Single-Seat Fighter. (Inter. Avia., No. $859-860,6 / 3 / 43$, p. 21.)

... Bloch 16r (SO x6r) Four-Engined Transport. (Inter. Avia., No. 86I, I $7 / 3 / 43$, Pp. I and I I-I 2.)

... SE 200 and Latécoère 63I Giant Flying Boats. (Inter. Avia., No. 861, 17/3/43, p. I 2.)

.. French Stratosphere Aircraft Proposed by CAPRA. (Inter. Avia., No. $861,17 / 3 / 43$, p. I3.) 
\begin{tabular}{rrr} 
ITEM & \multicolumn{2}{c}{ R.T.P. } \\
No. & \multicolumn{2}{c}{ REF. } \\
183 & 11188 & France \\
184 & 11189 & France \\
185 & $1147^{2}$ & France \\
186 & 11501 & France
\end{tabular}
TITLE AND JOURNAL.

.. Mauboussin M. 300 Trainer. (Flugsport, Vol. 35, No. $8,21 / 4 / 43$, p. 90 .)

Mauboussin M. 400 Transport Biplane. (Flugsport, Vol. 35, No. 8, $21 / 4 / 43$, p. 91.)

.. Loire-Nieuport Dive Bomber. (Inter. Avia., Vol. $867, \mathrm{r} / 5 / 43$, p. 10.)

.. Breguet 500 Transport Plane with High Lift Device $(C e=3 \max$.). (Inter, Avia., No. 868, $10 / 5 / 43$, p. 17.)

\section{Gliders.}

18710794 Germany ... Tailless Horten III Glider (Pilot in Prone Position). $\begin{array}{lll} & & \text { (Aeroplane, Vol. 64, No. I,666, 30/4/43, p. 501.) }\end{array}$ $26 / 2 / 43$, pp. I and 9.)
10918 U.S.A. $\quad \ldots \quad$ American Glider Development. (Inter. Avia., No. 859-860, 6/3/43, pp. 9-1o.)

s90 10947 Germany ... Messerschmitt Me. 323 Power Glider. (Inter. Avia., No. $86 \mathrm{r}, \mathrm{I} 7 / 3 / 43$, p. 9.)

19I III79 U.S.A. ... Army CG-4 Heavy Gliders (Photos). (Autom. Ind., Vol. 88 , No. $7,1 / 4 / 43$, p. 23.)

192 II307 France $\ldots$ Castel-Mauboussin Gliders $\left(C_{3}\right.$ O, $C_{3} \mathrm{OI} S, C_{3} \mathrm{I} P$, $L_{25} S$, etc.). (Flugsport, Vol. 35 , No. 1o, $16 / 6 / 43$, pp. 1 23-126.)

19311334 Germany ... Sail Plane Caudron C800 and C81o. (Flugsport, Vol. 35, No. 9, I9/5/43, pp. 105-107.)

\section{Aircraft Carriers.}

194 Io6 $_{58}$ G.B. ... ... Escort Carriers for Atlantic Convoys. (Flight, Vol. 43 , No. $1,786,27 / 5 / 43$, p. 559.)

19511231 G.B. ...

Ship Flying and Aircraft Carriers-1. (P. Bethell, Engineering, Vol. I 56 , No. 4,042, 2/7/43, pp. 1-4.)

I96 11278 G.B. ... ... "Seadromes" in the Atlantic. (Engineering, Vol. I 55, No. $4,041,25 / 6 / 43$, p. 508.)

$197 \quad I_{482}$ G.B. ... ... British Aircraft Carriers (Losses and Construction). (Inter. Avia., No. $867,1 / 5 / 43$, pp. 26-27.)

198 I 1757 Switzerland ... Floating Air Bases. (Inter. Avia., No. 869-870, $18 / 5 / 43$, p. 29.)

\section{AERODYNAMICS AND HYDRODYNAMICS.}

\section{General Aerodynamics.}

199 10854 U.S.A.

$200 \quad 11022$ Germany

The Influence of Sweep on the Spanwise Lift Distribution of Wings. (F. Theilheimer, J. Aeron. Sci., Vol. 10, No. 3, March, 1943, pp. 101-104.) Some Experiments on the Increase in the Maximum Lift of an Aerofoil Undergoing a Change of Incidence at a Constant Angular Velocity. (N. Scheubel, German Academy of Aeron. Research, Collected Reports No. I, 1942, pp. 37-45.)

20111023 Germany ... The Activated Flow. (A. Proll, German Academy of Aeron. Research, Collected Reports No. I, 1942, pp. 47-62.) 


\begin{tabular}{|c|c|c|}
\hline $\begin{array}{c}\text { ITEM } \\
\text { NO. }\end{array}$ & & $\begin{array}{l}\text { T.P. } \\
\text { EF. }\end{array}$ \\
\hline 202 & I I $57^{2}$ & Germat \\
\hline 203 & 10717 & U.S.A. \\
\hline 204 & 10853 & U.S.A. \\
\hline 205 & 10919 & U.S.A \\
\hline 06 & 11247 & U.S.A \\
\hline
\end{tabular}

10 10716 U.S.A.

21110719 U.S.A.

21210728 U.S.A.

$213 \quad 10819$ G.B. ... ...

$2 I_{4} \quad 10844$ Switzerland ..

215 I1040 G.B. ...

$216 \quad 11074$ G.B. ...

217 11163 G.B. ...

218 II 299 U.S.A.

2 I9 I 57 I Germany
TITLE AND JOURNAL.

The Effect of Compressibility on Thin Slightly Cambered Profiles at Subsonic Speeds. (W. Hantzsche and H. Wendt, Z.A.A.M., Vol. 22, No. 2, April, 1942, pp. 72-86.)

\section{Wind Tunnels.}

Wind Tunnel Tests to Determine Stack Heights (Dissipation of Flue Gases). (H. L. Von Hohenleiten and E. F. Wolf, Trans. A.S.M.E., Vol. 64, No. 7, Oct., 1942, pp. 671-683.)

Wind Tunnel Cooling. (A. N. Tifford, J. Aeron. Sci., Vol. ro, No. 3, March, I943, pp. 98-roo.) 700 m.p.h. Wind Tunnel at Pasadena. (Inter. Avia., No. $859-860,6 / 3 / 43$, p. 14.)

New Light Speed Low Density Refrigerated Wind Tunnel (600 m.p.h., 67 F., 40,000 ft.). (Sci. Am., Vol. I68, No. 6, June, I943, p. 276.)

\section{General Hydrodynamics.}

.. The Flow of a Flashing Mixture of Water and Steam Through Pipes. (M. W. Benjamin and J. G. Miller, Trans, A.S.M.E., Vol. 64, No. 7, Oct., 1942, pp. 657-669.)

Correlation of Coefficient of Friction with Drilling Torque and Thrust for Different Types of Cutting Fluids (Advantage of Sulphurised Oil Under Conditions of Seizure). (A. O. Schmidt and others, Trans. A.S.M.E., Vol. 64, No. 7, Oct., 1942, pp. 703-709.)

Heat Transfer Pressure Drop and Fouling Rates of Liquids for Continuous Longitudinal Fins (Laminar Flow). (A. T. Gunter and W. A. Shaw, Trans. A.S.M.E., Vol. 64, No. 8, Nov., 1942, pp. 795-804.)

Wave Analysis (Part III). (K. Browne, Elect. Eng., Vol. I 5, No. I84, June, 1942, pp. 31-36.)

Flou Investigations on Safety Device Incorporated in Hydraulic Power Installations. (C. Keller and I. Vaskovic, Escher-Wyss, No. 15-16, 1942-1943, pp. 191-202.)

Coefficient of Propulsive Efficiency (Marine Propellers). (K. C. Burnaby, Engineer, Vol. 175, No. $4,561,11 / 6 / 43$, pp. 472-475.)

Breakwaters (Contd.). (R. R. Minikin, Engineering, Vol. I 55 , No. $4,038,4 / 6 / 43$, pp. $441-443$.)

The Construction of Breakwaters. (R. R. Minikin, Engineering, Vol. I55, No. 4,040, 18/6/43, pp. 481-482.)

American Wartime Ship Construction. (Engineer, Vol. I 76, No. 4,564, 2/7/43, pp. 4-6.)

Water Seepage Through a Dam and Pressure Distribution Over Base. (H. Rossbach, Z.A.M.M., Vol. 22, No. 2, April, 1942, pp. 65-72.) 
ITEM

No. R.T.P. REF.

TITLE AND JOURNAL.

\section{AIRCRAFT, ACCESSORIES AND AIRSCREWS.}

\section{Civil and Experimental Aircraft.}

22010648 G.B. ... ... The Heston Phonix (Recognition Details). (Aeroplane, Vol. 64, No. 1,669, $21 / 5 / 43$, p. 60I.)

221 10659 G.B. ... ... The Mumford Helicopter (Early Experiments).

(Flight, Vol. 43, No. 1,786, 27/5/43, p. 561.)

22210735 G.B. ... ... The Heston Racer (including Photo), (Aeroplane, Vol. 64, No. 1,662, 2/4/43, pp. 378, 384.)

223 I0801 G.B. ... ... Control of the Heston Racer. (Aeroplane, Vol. 64, No. $1,666,30 / 4 / 43$, p. 520 .)

\section{General Design and Construction.}

22410657 G.B. ... $\quad \ldots \quad$ Early Designs of Tailless Aircraft. (Flight, Vol. 43 , No. $1,786,27 / 5 / 43$, pp. 556-557.)

22511092 Germany ... Problems of Aircraft Development. (A. Lippisch, Luftwissen, Vol. 1o, No. 4, April, 1943, pp. II 3-1 18 .)

$226 \mathrm{I}_{382}$ U.S.A. $\quad \ldots \quad U_{8 e}$ of Glue in Aireraft Construction. (J. T. Stephen, Aviation, Vol. 42, No. 3, March, 1943, pp. I $32-133$ and 3 II-323.)

22711420 G.B. ... ... Design for Freight Transport Plane for Perishable Goods (Photograph). (Metal Industry, Vol. 62, No. $25,18 / 6 / 43$, p. 394.)

22811446 U.S.A. ... Design Considerations for Plywood Structures. Part IV-Wings. (L. J. Marhoefer, Aviation, Vol. 42, No. 4, April, 1943, pp. $164-167$ and 360-364.)

\section{Stability and Control.}

229 I1055. U.S.A. _.. Study of Flutter Problems. (Sci. Am., Vol. 168, No. 5, May, 1943, p. 220.)

$23^{\circ} 10851$ U.S.A. $\quad$.. Note on Paper Entitled "Proportioning a Canard for Longitudinal Stability and Safety Against Stall" (Dec., I942). (F. V. Foa, J. Aeron. Sci., Vol. Io, No. 3, p. 90.)

.23111264 U.S.A. $\quad \ldots$ Torsional and Aileron Flutter. (Z. Krzwoblocki, J. of Aeron. Sci., Vol. Io, No. 5, May, 1943, pp. 161-168.)

${ }_{232}{ }^{11352}$ Germany ... Device for the Dynamic Stabilisation of Aircraft. (Pat series No. 4, 733,588.) (Junkers, Flugsport, Vol. 35, No. 9 , 19/5/43, pp. 25-26.)

.233 I1263 U.S.A. ... A New Method of Longitudinal Control for Aircraft by Use of an Adjustable Angle of Attack Balance. (R. J. White, J. of Aeron. Sci., Vol. ro, No. 5, May, 1943, pp. r 52-160.)

234 I1353 Germany ... Automatic Device for Limiting the Vertical Acceleration of Aircraft. (Pat. series No. 4, 733,58I.) (Potez, Flugsport, Vol. 35, No. 9, I $9 / 5 / 43$, p. 26.) 
ITEM R.T.P.

NO. REF.

TITLE AND JOURNAL.

\section{Take-off.}

23511024 Germany ... The Rôle of Composite Aircraft in Comparisun with Other Methods of Assisted Take-off. (W. Hoff, German Academy of Aeron. Research, Report No. I, 1942, pp. I-35.)

236 II 468 Germany ... Nazi Rocket Take-offs? (Aviation, Vol. 42, No. 4, April, 1943, p. 312.)

\section{Performance and Testing.}

237 107I3 U.S.A.

Test Stand for Centrifugal and Propeller Pumps. (G. F. Wislicenus, Trans. A.S.M.E., Vol. 64, No. 6, Aug., 1942, pp. 619-624.)

$238 \quad 10848$ U.S.A. $\quad$.. Mancuvrability Criteria Through Turning Performance. (J. E. Goode, J. Aeron. Sci., Vol. Io, No. 3, March, 1943, pp. 73-80.)

$2391143^{6}$ U.S.A.

Flight Testing. (E. T. Allen, Aviation, Vol. 42, No. 4, April, 1943, pp. I08-I I 2.)

\section{Post-War Aviation.}

$240 \quad 10627$ G.B. ...

Air Freight. (W. A. Patterson, Flight, Vol. 43, No. I,795, 20/5/43, p. 532.)

24I I0663 G.IB. ..

An Empire Air Council (Lord Bennet's Proposal). (Aeroplane, Vol. 64, No. I,668, 14/5/43, p. 551.)

$242 \quad 10747$ G.B. ...

The Board of British Overseas Airways Corporation and Air. Transport Command. (Aeroplane, Vol. 64, No. 1,662, 2/4/43, p. 402.)

243 I0795 G.B. ...

Shipowners and Air Transport. (R. H. Thorton, Aeroplane, Vol. 64, No. 1,666, 30/4/43, pp. 502-503.)

244 I0798 G.B. ..

An International Air Port Plan. (Aeroplane, Vol. 64, No. r,666, 30/4/43, pp. 506-507.)

24510800 U.S.A.

$246 \quad 1269$ U.S.A.

247 II3OI G.B. ...

U.S.A. and Post-War Bases in the Pacific. (Aeroplane, Vol. 64, No. I $666,30 / 4 / 43$, p. 516.)

Post-War Aviation (Paper Presented at R. Aero. Soc.). (E. Warner, Engineer, Vol. 175, No. $4,5^{6} 3,25 / 6 / 43$, pp. 506-507.)

The S.B.A.C. and Civil Aviation. (Engineer, Vol. 176, No. 4,564, 2/7/43, pp. Io- I and I7.)

$248 \quad 1145^{6} \quad$ U.S.A.

Post-War Preview of European Airways. (M. A. Garbell, Aviation, Vol. 42, No. 4, April, 1943, pp. 202-203, 337-338.)

249 II47 I Switzerland ... Flying Boat or Land Plane for Civil Aviation. (Inter. Avia., No. $867,1 / 5 / 43$, pp. 1-5.)

\section{Propellers.}

$25^{\circ} 10869$ U.S.A. $\quad \ldots$ New Dual Counter-Rotating Propeller (Hamilton). (Sci. Am., Vol. 168, No. 4, April, 1943, p. 183.)

251 11097 G.B. . .

... Propeller Sense. (A.M. Pamphlet I53.)

252 I1190 France

.. Nozzle Propellers and Jet Propulsion (Rateau. Auxionuary). (Flugsport, Vol. 35, No. 8, $21 / 4 / 43$, pp. $92-95$.

253 I1193 Germany .... Method of Attachment for Leading Edge Protertion Plate on Wooden Airscrews. (Pat. series. No. 3, 730,097.). (H. Heine, Flugsport, Vol. 35. No. $8,21 / 4 / 43$, p. I 3 .) 


\begin{tabular}{|c|c|c|c|c|}
\hline $\begin{array}{c}\text { ITEM } \\
\text { NO. }\end{array}$ & & EF. & & TITLE AND JOURNAL. \\
\hline 254 & I I I I 95 & Germany & $\ldots$ & $\begin{array}{l}\text { Variable Pitch Propeller with Rapid Decrease in } \\
\text { Pitch for Braking Purposes. (Pat. series No. 3, } \\
\text { 730,552.) (C. R. Waseige, Flugsport, Vol. 35, } \\
\text { No. 8, 21 } / 4 / 43 .)\end{array}$ \\
\hline 255 & I I 196 & Germany & $\ldots$ & $\begin{array}{l}\text { Combined Throttle and Pitch Change Control. } \\
\text { (Pat. series No. 3, 731,340.) (Heinkel, Flugs- } \\
\text { port, Vol. 35, No.8,21/4/43, p. 14.) }\end{array}$ \\
\hline 256 & I I 197. & Germany & $\cdots$ & $\begin{array}{l}\text { Method for Locking Blade of a Hydraulically } \\
\text { Operated V.P. Airscrew. (Pat. series No. 3, } \\
730,378 \text { and } 731,986 .) \text { (Escher Wyss, Flugsport, } \\
\text { Vol. 35, No. 8, 21/4/43, pp. I4 and I5-16.) }\end{array}$ \\
\hline 257 & I 1198 & Germany & $\ldots$ & $\begin{array}{l}\text { V.P. Operation by Means of an Electric Motor } \\
\text { Freely Mounted on Propeller Hub, Torque Re- } \\
\text { action being Balanced by Means of a Wind Vane. } \\
\text { (Pat. series No. 3,730,553.) (Argus, Flugsport, } \\
\text { Vol. 35, No. } 8,21 / 4 / 43 \text {, pp. 14-15.) }\end{array}$ \\
\hline 258 & I 1200 & Germany & $\cdots$ & $\begin{array}{l}\text { Variable Speed Blade Setting for V.P. Airscrews. } \\
(\text { Pat. series No. 3, 730,554.) (V.D.M., Flugs- } \\
\text { port, Vol. 35, No.8, } 21 / 4 / 43, \text { p. I5.) }\end{array}$ \\
\hline 259 & I I 202 & Germany & $\ldots$ & $\begin{array}{l}\text { Airscrew Blade Pounded with Adjustable Longi- } \\
\text { tudinally Projecting Tip. (Pat. series No. 3, } \\
\text { 732,051.) (Junkers, Flugsport, Vol. 35, No. 8, } \\
\text { 21/4/43, p. 16.) }\end{array}$ \\
\hline 260 & I 1203 & Germany & $\ldots$ & $\begin{array}{l}\text { Blade Control with Varying Sensitivity. (Pat. } \\
\text { series No. 3, 730,900.) (Argus, Flugsport, Vol. } \\
\text { 35, No. } 8,21 / 4 / 43, \text { p. 16.) }\end{array}$ \\
\hline 261 & 11402 & U.S.A. & $\ldots$ & 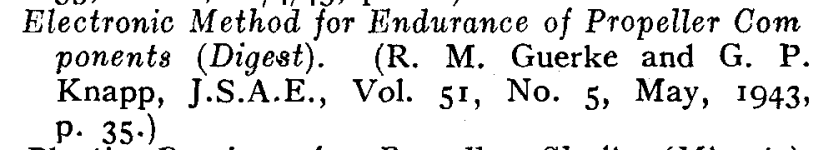 \\
\hline 262 & 11409 & U.S.A. & $\ldots$ & $\begin{array}{l}\text { Plastic Bearings for Propeller Shafts (Micarta). } \\
\text { (Ind. and Eng. Chem., Vol. } 2 \mathrm{I} \text {, No. 8, 25/4/43, } \\
\text { p. 560.) }\end{array}$ \\
\hline 263 & $1145^{8}$ & U.S.A. & $\ldots$ & $\begin{array}{l}\text { Dynamic Balancing in Propeller Maintenance. } \\
\text { (B. J. Cumnock, Aviation, Vol. } 42 \text {, No. 4, April, } \\
\text { 1943, pp. } 2{ }_{4} \text { and 403.). }\end{array}$ \\
\hline 264 & 11475 & U.S.A. & $\cdots$ & $\begin{array}{l}\text { American Contra-Rotating Airscrews (Curtiss } \\
\text { General Motors, Hamilton). (Inter. Avia., No. } \\
867, \mathrm{I} / 5 / 43, \mathrm{pp} . \mathrm{I} \text { and I } 2-\mathrm{I} 3 .)\end{array}$ \\
\hline 265 & 11667 & U.S.A. & & $\begin{array}{l}\text { Anti-Icing Propeller Covers. (Aero Digest, Vol. } \\
\text { 42, No. 5, May, 1943, p. 409.) } \\
\text { Rotating-Wing Aircraft. }\end{array}$ \\
\hline 266 & ${ }_{113} 18$ & Germany & . & $\begin{array}{l}\text { Blade. Control for Helicopter Fitted with Two In- } \\
\text { clined Rotors, Altitude and Direction. (Pat. } \\
\text { series No. 5, 732,735.) (Focke, Flugsport, Vol. } \\
\text { 35, No. 10, 16/6/43, pp. 30-31.) }\end{array}$ \\
\hline 267 & I I319 & Germany & $\ldots$ & $\begin{array}{l}\text { Incidence Distribution for Autogyro Blades. (Pat. } \\
\text { series No. 5, } 733 \text {, or I.) (Asboth, Flugsport, Vol. } \\
\text { 35, No. ro, } 16 / 6 / 43, \text { p. } 3^{\mathrm{I}} \text { ) }\end{array}$ \\
\hline 268 & 11320 & Germany & $\ldots$ & $\begin{array}{l}\text { Pendulum Stabilisation for Autogyros. (Pat. series } \\
\left.\text { No. } 5,73^{2}, 924 .\right) \text { (Wertenson, Flugsport, Vol. } \\
\text { 35, No. 10, 16/6/43, p. } 3 \text { r.) }\end{array}$ \\
\hline 2 & II32I & any & $\ldots$ & $\begin{array}{l}\text { Tethering Device for Helicopters (Four Point). } \\
\text { (Pat. series No. } 5,733,86 \text { I.) (A.E.G., Flugsport, } \\
\text { Vol. } 35 \text {, No. 10, } 16 / 6 / 43, \text { p. } 3^{2 .)}\end{array}$ \\
\hline
\end{tabular}




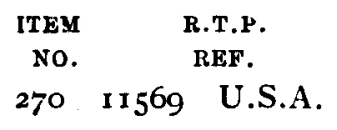

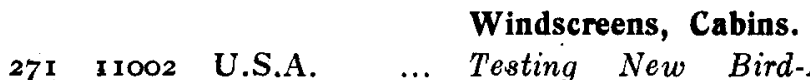

272 I I209 Germany

$273 \quad 11338$ Germany

274 II339 Germany

275 I $134^{\circ}$ Germany

276 II34I Germany

277 п 396 U.S.A.

$278 \quad$ II342 Germany

279 I 1343 Germany

280 I 1344 Germany

281 11345 Germany

282 I 346 German

283 I 1347 Germany

284 I 348 Germany

28511349 Germany p. 17.) p. 22.) 19/5/43, p. 22.) 19/5/43, p. 23.) I9/5/43, p. 24.)
TITLE AND JOURNAL.

A Method of Rapid Estimation of Helicopter Performance. (Q. Weld, J. Aeron. Sci., Vol. Io, No. 4, April, 1943, pp. I3 ${ }^{\text {I-I35.) }}$

(Autom. Ind., Vol. 88, No. 6, 15/3/43, p. 142.)

Oil Hydraulic System for Pressure Control in Pressure Cabin. (Pat. series No. 3, 731,646.) (Henschel, Flugsport, Vol. 35, No. 8, 21/4/43,

.. Quick Release Opening for Pressure Cabins. (Pat. series No. 4, 732,9I5.) (Arado, Flugsport, Vol. 35, No. 9, 19/5/43, p. 21.)

Anti-Dazzle. Device for Nose Cockpits. (Pat. series No. 4, $73^{2}, 3^{83}$.) (Heinkel, Flugsport, Vol. 35, No. 9 , I $9 / 5 / 43$, p. 2 I.)

Anti-Draught Device for Cockpit Windows. (Pat. series No. 4, 732,705.) (Junkers, Flugsport, Vol. 35, No. 9, 19/5/43, p. 21.)

Sealed Cavity Window for Prèssure Cabins. (Pat. series No. 4, 732,916.) (Junkers, Flugsport, Vol. 35, No. $9,19 / 5 / 43$, pp. $21-22$.)

Bird-Resisting Windshield (Digest). (A. L. Morse, J.S.A.E., Vol. 5I, No. 5, May, 1943, p. 27.)

Wings and Flaps, etc.

Improvements in the Effectiveness of Control Surfaces (Air Ejection). (Pat. series No. 4, 732,536.) (Junkers, Flugsport, Vol. 35, No. 9, 19/5/43,

Flapped Wing with Suction Control at Edge. (Pat. series No. 4, 733, I I4.) (H. V. A. Goethinger, Flugsport, Vol. 35 , No. 9, 19/5/43, p. 22.)

Suction Control for Wing Flaps. (Pat. series No. 4, 733,445.) (Arado, Flugsport, Vol. 35, No. 9,

Variable Camber Flap Control. (Pat. series No. 4, 732,918.) (Heinkel, Flugsport, Vol. 35, No. 9,

Sealing Plate for Flaps Capable of Aileron Action. (Pat. series No. 4, 733,493.) (Heinkel, Flugsport, Vol. 35, No. 9 , 19/5/43, p. 23.)

Wing Spoiler (Automatic Action). (Pat. series No. $4,733,504$.$) (D. F. S. Darmstadt, Flugsport,$ Vol. 35, No. $9,19 / 5 / 43$, p. 23.)

One Piece Sheet Metal Wing with Integral Webs (Produced by Folding). (Pat. series No. 4, 732, 594.) (Henschel, Flugsport, Vol. 35, No. 9,

Wing Structure Consisting of Two. Shells Incorporating Flanges for Spars. (Pat. series No. 4, 732,919.) (Arado, Flugsport, Vol. 35, No. 9, 19/5/43, pp. 24-25.) 
ITEM R.T.P.

No. REF.

$286 \quad 1135^{1}$ Germany

287 I 354 Germany

288 I1355 Germany
TITLE AND JOURNAL.

Variable Surface Wing. (Pat. series No. 4, 732,537.) (J. Gerrin, Flugsport, Vol. 35, No. 9 , I $9 / 5 / 43$, p. 25.)

Adjustable. Mass Balance for the Control Surfaces of Experimental Aircraft. (Pat. series No. 4, $\left.73^{2}, 920.\right)$ (Arado, Flugsport, Vol. 35, No. 9 , I $9 / 5 / 43$, p. 26.)

Device for the Coarse and Fine Adjustment of Trimming Tabs. (Pat. series No. 4, 733,543.) (Arado, Flugsport, Vol. 35, No. 9, I9/5/43, p. 27.)

\section{Landing Gear and Brakes.}

28910639 G.B. ...

... Aeroplane Wheels. (Aeroplane, Vol. 64, No. I,670, 28/5/43, pp. 620-629.)

$290 \quad 11007$ U.S.A.

Reducing Brake Drum and Wheel Rim Temperature. (Autom. Ind., Vol. 88, No. 6, I5/3/43, pp. 358.)

291 11059 U.S.A.

Non-Skid Wire Tread for Aircraft Tyres. (Sci. Am., Vol. 168, No. 5, May, I943, p. 224.)

2921 III94 Germany

Device for Mounting Float Seaplanes on a Trolley. (Pat. series No. 3, 730,216.) (Bachmann, Flugsport, Vol. 35 , No. 8, $21 / 4 / 43$, p. 2o.)

29311206 Germany

Contact Rod Height Indicator for Landing. (Pat. series No. 3, 731,647.) (Nitzschte, Flugsport, Vol. 35 , No. 8, $21 / 4 / 43$, pp. 19-20.)

294 II322 Germany

Automatic Deflation of Landing Wheel Tyres on Retraction and Subsequent Inflation when Lowered (Smaller Wing Housing). (Pat. series No. 5, 732,327.) (Messerschmitt, Flugsport, Vol. 35, No. 10, 16/6/43, pp. 32-33.)

29511323 Germany ... Spring Suspension of Snow Skids. (Pat. series No. 5, 732,538.) (Henschel, Flugsport, Vol. 35, No. Io, $16 / 6 / 43$, p. 33 .)

296 I 1324 Germany ... Interconnection of Throttle and Tail Wheel Swivel Lock. (Pat. series No. 5, 732,485.) (Henschel, Flugsport, Vol. 35, No. 10, 16/6/43, p. 33.)

297 II 325 Germany $\quad$... Spring Mounting for Tail Wheel (Composite Rubber Metal). (Pat. series No. 5, 733, I3r.) (Gotha, Flugsport, Vol. 35, No. 10, 16/6/43, pp. 33-34.)

$298 \quad 11326$ Germany ... Interconnection of Rudder and Tail Wheel Swivel Lock. (Pat. series No. 5, 733,683.) (Fieseler, Flugsport, Vol. 35, No. 10, 16/6/43, p. 34.)

29911327 Germany ... Arrangement of a Central Skid to Facilitate Landing. (Pat. . series No. 5, 732,486.) (Arado, Flugsport, Vol. 35 , No. Io, 16/6/43, pp. 34-35.) 300 II328 Germany ... Retracting Landing Wheel Mechanism. (Heinkel, Flugsport, Vol. 35, No. 1o, 16/6/43, p. 35.)

30111329 Germany ... Utilisation of Shock Absorber Deflections to Compress Fluid for Operating Brakes. (Pat. series No. 5, 73I,379.) (Elecktron, Flugsport, Vol. 35, No. Io, 16/6/43, pp. 35-36.)

30211330 Germany
Aerodynamic Tail Brake. (Pat. series No. 5: 730,606.) (Dornier, Flugsport, Vol. 35, No. 10, $16 / 6 / 43$, p. $3^{6}$.) 
ITEM R.T.P.

No. REF.

TITLE AND JOURNAL.
303 I I33I Germany
30411435 Germany ... Friction Brake. (G. Niemann, Symposium of Papers on the Elements of Machine Design (Aachen), pp. 62-64.)

\section{De-icing.}

305 Ir332 Germany $\quad \ldots \quad$ Ice Warming Device (Photo-Electric). (Pat. series No. 5, 731,905.) (German Government, Flugsport, Vol. 35, No. 1o, 16/6/43, p. 36.)

$306 \quad$ I 397 U.S.A. $\quad \ldots$ Double Wind Shield with Hot Air Space (Digest). (R. L. McBrien, J.S.A.E., Vol. 51, No. 5, May, I943, pp. 27-28.)

\section{ENGINES AND ACCESSORIES.}

\section{Named Types.}

$307 \quad 10617$ G.B. ...

The 2,000 h.p. Napier 24-Cylinder, Liquid-Cooled, H Type Sabre Engine (Photograph). (Aircraft Production, Vol. 5, No. 56, June, I943, p. 302.) 30810933 U.S.A. ‥ Allison Engine $V_{1,710}$ Performance. (Inter. Avia., No. $856-857$, I $5 / 2 / 43$, pp. 1 3-1 4.)

$309 \quad 10937$ G.B. ...

Bristol Centaurus (8-Cylinder Twin-Row Radial $(\sim 2, \infty$ h.p. $)$ (Inter. Avia., No. 856-857, I $5 / 2 / 43$, p. 19.)

$310 \quad 1093^{8}$ G.B. . Sabre 24-Cylinder Sleeve Valve Engine Fitted to Typhoon. (Inter. Avia., No. $856-857,15 / 2 / 43$, p. 19.)

3 II 10993 U.S.A.

312 I0994 U.S.A.

merican Aircraft Engines (Index). (Autom. Ind., Vol. 88, No. 6, I 5/3/43, pp. I I0-I I I.)

American Gasoline Engines (Index). (Autom. Ind., Vol. 88, No. 6, I 5/3/43, pp. I I 2-I 2 I.)

3I3 10997 U.S.A.

Small Gasoline Power Units (1о h.p. or less) (Index of American Types). (Autom. Ind., Vol. 88 , No. 6 , I $5 / 3 / 43$, p. I 26.)

3 I4 III9I Germany ... B.M.W. 80I Aero Engine (Sectional Drawing). (Flugsport, Vol. 35, No. 8, $21 / 4 / 43$, p. 96.)

$3^{\text {I } 5} 1145^{2}$ U.S.A.

Diagrammatic Layout of Two-Stage Supercharger in Merlin 61 Engine. (Aviation, Vol. 42, No. 4, April, 1943, p. 187.)

$3_{16} 11544$ Germany ... German Automatic Supercharging System in Mercedes-Benz D.B. 6orA (M.A.P. Report). (Engineer, Vol. I 76 , No. $4,566,16 / 7 / 43$, pp. 48-49.)

\section{Design and Installation.}

317 I0846 U.S.A. ... Advantages of Air-Cooled Radial and LiquidCooled Inline Engines Installed in Modern American Aircraft. (E. M. Lester, Pegasus, Vol. I, No. 2, Feb., I943, pp. 4-7 and I 2-1 5.)

$3^{18} \quad 1097^{6}$ G.B. ... Surface Finish and the Function of Parts-A Comparison of British and German Aero Engine Parts. (G. Schlesinger, Engineer, Vol. 175, No. 4,560, 4/6/43, pp. 454-456.)

3191207 Germany $\ldots$ Tiltable Power Plant for Aircraft. (Pat. series No. 3. 730,943.) (B.M.W., Flugsport, Vol. 35, No. $8,21 / 4 / 43$, p. 17.) 


\begin{tabular}{|c|c|c|}
\hline $\begin{array}{r}\text { ITEM } \\
\text { NO. }\end{array}$ & \multicolumn{2}{|c|}{$\begin{array}{l}\text { R.T.P. } \\
\text { REF. }\end{array}$} \\
\hline $3^{20}$ & I I 2 I I & Germany \\
\hline $3^{2 I}$ & 11392 & U.S.A. \\
\hline $3^{22}$ & I I $40^{\circ} 3$ & U.S.A. \\
\hline $3^{2} 3$ & I 1404 & U.S.A. \\
\hline $3^{24}$ & I 1434 & Germany \\
\hline & $1157^{\circ}$ & U.S.A. \\
\hline
\end{tabular}

TITLE AND JOURNAL.

.. Radiators Installed Inside Engine Cowling. (Pat. series No. 3,730,497.) (Arniot, Flugsport, Vol. 35 , No. $8,21 / 4 / 43$, p. 18 .)

New Materials for Aircraft Engines. (M. Young and H. H. Haninks, J.S.A.E., Vol. 51, No. 5, May, 1943, pp. 157-164.)

Co-Designing Aircraft Power Plants (Digest). (H. Karcher, J.S.A.E., Vol. 5I, No. 5, May, 1943, p. 3o.)

p. $3^{\circ}$.)
General Aspects of Aircraft Power Plant Installations (Digest). (T. Hammon, J.S.A.E., Vol. 51, No. 5, May, 1943, pp. 31-32.)

Development in Gear Design (with Discussion). (O. Wolf, Symposium of Papers on the Elements of Machine Design (Aachen).)

$\begin{array}{lll}326 & 10516 & \text { G.B. ... } \\ 327 & 10811 & \text { G.B. ... }\end{array}$

Pendulum Type Vibration Absorber (Discussion). (A. H. Shieh, J. Aeron. Sci., Vol. Io, No. 4, April, 1943, p. I 35.)

\section{Performance and Testing.}

... Prevention of Valve Seizure. (Engineer, Vol. 175, No. $4,55^{8}, 21 / 5 / 43$, p. 416 .)

Some Recent Applications to Thermodynamics in Steam Engineering Research (Boiler Problems, Cavitation, Flow Through an Orifice De-aeration). (R. S. Silver and others, Journal of Scientific Instruments, Vol. 20, No. 4, April, 1943, pp. 53-58.)
$3^{28} \quad 10879$ G.B. ... ... Fuels and Internal Combustion Engine Perform- ance. (J. L. Beilschmidt, Aeronautics, Vol. 8, No. 4, May, 1942, pp. 48-54.)
329 I 1001 U.S.A. ... Portable Engine Test Stand (Photograph). (Autom. Ind., Vol. 88, No. 6, I $5 / 3 / 43$, p. 140.)
33011268 U.S.A. _. Breaking-in an Aero Engine. (Engineer, Vol. 175, No. $4,563,25 / 6 / 43$, p. 505 .)
$33^{1} 11395$ U.S.A. ... Mock Up Speeded Chevrolet Engine Test-Cell Project (Digest). (P. A. Collins, J.S.A.E., Vol. $5^{1}$, No. 5, May, 1943, pp. 25-26.)
$33^{2} \quad 11398$ U.S.A.
Improving the Fatigue Strength of Engine Parts (Digest). (J. O. Almen, J.S.A.E., Vol. 51, No. 5, May, 1943, pp. 28-29.)
33311671 U.S.A. ... High Speed Tests of Conventional Radial Engine Cowlings. (R. G. Robinson and J. V. Becker, N.A.C.A. Report No. 745.)
$334 \quad \mathrm{I} 745$ U.S.A.
The Effect of Environment on Aircraft Engine Design and Performance. (L. T. Miller, S.A.E. Preprint, Nat. Aeron. Meeting, April 8-9, 1943.) Diesel and Oil Engines.
33510995 U.S.A. $\quad \ldots \quad$ American Automotive Diesel and Other Heavy Oil Engines (Index). (Autom. Ind., Vol. 88, No. 6, 15/3/43, pp. 122-125.)
336 I1431 Germany ... The Stresses in the Transmission Gear and Bearings of High Speed Diesel Engines. (D. Schmidt, Symposium of Papers on the Elements of Machine Design (Aachen), pp. 44-47.)




\section{Turbines (Gas, Steam, Water).}

337 1063r G.B. ... ... Turbines and the Flying Wing. (G. G. Smith,

Flight, Vol. 43, No. I,794, I3/5/43, pp. 496-498.)
$33^{8} 10697$ G.B. ... ... Fabrication of Water Turbines. (H. Stone, Weld- ing, March, 1943, $p p$. I35-148.) (Met. Vick.
Tech. News Bull., No. $859,26 / 3 / 43$, p. 4.)

33910714 U.S.A.

339 10714 U.S.A.

$340 \quad 10715$ U.S.A.

34110806 G.B. .

$342 \quad 10834$ Switzerland ...

$343 \quad 10835$ Switzerland ...

$344 \quad 10836$ Switzerland ...

$345 \quad 10837$ Switzerland ...

$346 \quad 1084$ I $\quad$ Switzerland ...

$347 \quad 10842$ Switzerland ...

$\begin{array}{ccc}348 & 10838 & \text { Switzerland ... } \\ 349 & 10898 & \text { Switzerland ... }\end{array}$

The Mercury Vapour Process (Combined Mercury and Steam Turbines). (A. R. Smith and E. S. Thompson, Trans. A.S.M.E., Vol. 64 , No. 7 , Oct., 1942, pp. 625-646.)

The Mercury Boiler. (R. N. Hackett, Trans. A.S.M.E., Vol. 64, No. 7, Oct., r942, pp.

647-656.)
New Gas Turbine, Projects. (Flight, Vol. 43, No. I,793, 6/5/43, pp. 473-476.)

Aerodynamic Test Engines (Closed Circuit). (J. Ackeret and C. Keller, Escher Wyss, No. 15-16, 1942-1943, pp. 5-19.)

Comparison of Aerodynamic (Closed Circuit) Turbines with Gas and Steam Turbines. (C. Keller, Escher Wyss, No. 15-16, 1942-1943, pp. 20-41.) Rôle of Research in Turbine Design. (C. Keller, Escher Wyss, No. 15-16, 1942-1943, pp. 42-53.) New Developments in Escher Wys8 Steam Turbines. (F. Flatt, Escher Wyss, No. 15-16, 19421943, pp. 54-61.)

Ioo Years Development of Water Turbines. (J. Moser, Escher Wyss, No. I5-16, 1942-1943, pp. IOI-I I9.)

Researches on the Energy Consumed by Water Turbine Controls. (H. Gerber, Escher Wyss, No. I5-16, 1942-1943, pp. I 51-157.)

Governors for Steam Turbines. (A. Luthi, Escher Wyss, No. I5-16, 1942-1943, pp. 84-89.)

Investigation of Water Turbines Regulators (from Schweizerische Bauzeitung, Vol. 120, No. 2, I $1 / 7 / 42$.) (H. Gerber, Eng. Digest, Vol. 4, No. I, Jan., 1943, pp.5-10.)

$35^{\circ}$ Irogr Germany ... The Experimental Determination of the Blade Temperature of Exhaust Gas Turbine. Under Load. (E. Graus, Luftwissen, Vol. 1o, No. 4, April, I943, pp. I IO-I I3.)

$35^{1}$ 107.12 U.S.A. ... Some Problems in the Selection and Operation of Centrifugal Pumps for Oil and Petrol Pipe Lines. (A. Hollander, Trans. A.S.M.E., Vol. $\overline{6} 4$, No. 6, Aug., 1942, pp. 607-617.)

\section{Compressors, Pumps, Generators.}

$35^{2}$ I0710 U.S.A. ... Energy Transfer Between a Fluid and a Rotor for Pump and Turbine Machinery (with Discussion). (S. A. Moss and others, Trans. A.S.M.E., Vol. 64, No. 6, Aug., 1942, pp. 567-597.) 


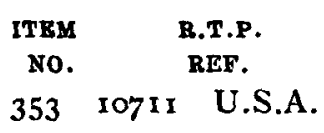

354 I0721 U.S.A.

355 ro820 G.B. ..

356 I1025 Germany ... Determination of the Lowest Natural Bending Frequency of Axial Flow Compressor Blades. (M. Schilhans1, German Academy of Aeron. Research, Report No. 1, 1942, pp. 63-95.)

357 I 1049 G.B. ... ... Large. Wind Driven Synchronous Generators (Contd.). (T. F. Wall, Engineering, Vol. I55, No. 4,039, 1 I/6/43, pp. 46I-463.)

358 11273 G.B. ... ... Large Wind Driven Synchronous Generators-II. (T. F. Wall, Engineering, Vol. I55, No. 4,041, $25 / 6 / 43$, pp. 5or-503.)

Cylinders, Bearings.

359 rog64 G.B. ... ... The Quality of High Duty Bearings. (M. H. Gall, Engineering Inspection, Vol. 7, No. I, Jan.March, 1942, pp. 26-30 and 32.)

$3^{60} 11393$ U.S.A. ... The Influence of Lubricating Oil Viscosity on Cylinder Wear. (H. A. Everett, J.S.A.E., Vol. 5I, No. 5, May, I943, pp. 165-169.)

361 Ir401 U.S.A. ... Cooling Characteristics of Steel and Al. Tinned Cylinders for In-line Air-Cooled Engines. (M.

Piry,J.S.A.E., Vol. 51, No. 5, May, 1943, p. 37.)

362 II430 Germany ... Experiment on the Transmission of Pressure in a Lubricated Bearing. (W. Pepper, Symposium of Papers on the Elements of Machine Design (Aachen), pp. 42-45.)

\section{Intercoolers, Oil Intakes.}

$3^{6}{ }_{3} \mathrm{I}_{381} \mathrm{I}$ U.S.A. ... Intercoolers and Their Performance in Aircraft. (S. K. Anderson and P. A. Scherer, Aviation, Vol. 42, No. 3, March, 1942, pp. 125-129 and $333-33^{8 .)}$

$3^{64}$ II399 U.S.A. ... Aircraft Oil Systems-High Altitude Problems (Digest). (H. E. Moerman, J.S.A.E., Vol. 51, No. 5, May, 1943, pp. 29-3o.)

365 1 1400 U.S.A. ... Intake Systems for Aircraft Engines (Digest). (C. T. Doman, J.S.A.E., Vol. 5I, No. 5, May, 1943, pp. 36-37.)

366 I 1683 G.B. ... ... Engine Oil Filtration and its Effects on Wear in Internal Combustion Engines. (T. W. Langley, Mech. World, Vol. I1 4 , No. 2,949, 9/7/43, pp. 37-39 and 48.) 


$\begin{array}{rrr}\text { ITEM } & \text { R.T.P. } \\ \text { No. } & \text { REF. } \\ 367 & \text { I0651 } & \text { G.B. ... } \\ 368 & \text { II183 } & \text { U.S.A. } \\ 369 & \text { II391 } & \text { U.S.A. }\end{array}$

TITLE AND JOURNAL.

\section{Starters.}
An Aeroplane Starter for Electrically Started Aero- plane Engines. (Aeroplane, Vol. 64, No. 1,669, 21 $/ 5 / 43$, p. 602.)
Portable Electric Starter Unit for Aircraft. (Autom. Ind., Vol. 88, No. 7, 1/4/43, p. 43.)
.. Storage Battery Performance at Low Temperatures (Engine Starting). (J. H. Little and R. A. Daily, J.S.A.E., Vol. 5r, No. 5, May, 1943, pp. 149- I56 and 164.$)$

\section{FUELS AND LUBRICANTS.}

High Octane and Aviation Fuels.

$\begin{array}{lll}370 & 10988 & \text { G.B. ... } \\ 371 & \text { I } 124^{2} & \text { U.S.A. } \\ 37^{2} & 11464 & \text { U.S.A. }\end{array}$

... Fuel Research Intelligence Section. (Fuel Research Station, Summary for Two Weeks ending 8th and 15 th May, 1943.)

Gas Analysis by Means of Spectrometer (Applied to the Manufacture of High Octane. Fuels). (Sci. Am., Vol. 168, No. 6, June, 1943, p. 254.)

$\begin{array}{lll}373 & \text { ro821 } & \text { Germany } \\ 374 & \text { Iro45 } & \text { G.B. ... } \\ 375 & \text { Ir543 } & \text { G.B. ... }\end{array}$
New Aviation Fuel Processes. (Aviation, Vol. 42, No. 4, April, 1943, p. 3or.)

\section{Gaseous Fuels.}

German Portable Gas Producer Practice. (Engineering, Vol. I55, No. 4,031, 28/5/43, pp. 423-425.)

Producer Gas Tests on a Petrol Engine. (Engineering, Vol. 155, No. 4,039, II/6/43, p. 465.)

Storage of Liquefied Natural Gas. (Engineer, Vol. I 76 , No. $4,566,16 / 7 / 43$, p. 48 .)

\section{Lubrication.}

$376 \quad$ 10760 U.S.A.

Lubricants and Their Dimensional Value in Gear Design (Paper Presented to S.A.E.). (J. O. Almen, Autom. Eng., Vol. 33, No. 435, April, 1943, pp. 147-153.)

377 I 1018 U.S.A. ... Boundary Lubrication. (Metal Progress, Vol. 43, No. 4, April, 1943, pp. 582-584.)

378 I1 302 G.B. ...

Lubricants from Tree Stumps. (Engineer, Vol. 176 , No. $4,564,2 / 7 / 43$, p. II.)

379 I1429 Germany

$380 \quad 1143^{2}$ German

Boundary Lubrication (with Extensive Bibliography). (H. Donandt, Symposium of Papers on the Elements of Machine Design (Aachen), 1935, pp. 33-4I.)

Lubrication of Railway Axles. (D. Garhers, Symposium of Papers on the Elements of Machine Design (Aachen), pp. 47-49.)

Oil Testing. $381 \quad 11580 \quad$ U.S.A. $\quad \ldots \quad A \begin{gathered}\text { Versatile Oil-Testing Cell of Novel Design for Use } \\ \text { in Determining Electrical Properties of Insu- }\end{gathered}$ lating Oils (Liquid Dielectrics, etc.). (T. Hayen, Rev. of Sci. Instrum., Vol. I4, No. 5, May, 1943, pp. 141-143.) 


\section{THEORY OF ELASTICITY.}

\section{Stresses.}

$3^{82} \quad 10897$ G.B. ... $\quad \ldots$ Code for Working Stresses-Pt. I. (J. Marin, Eng.

Digest, Vol. 4, No. I, Jan., I943, pp. 2-5.)

${ }_{383} 11048$ G.B. ... ... Stress Due to Collapse of Vapour Bubbles in a Liquid (Contd.). (R. S. Silver, Engineering, Vol. I55, No. 4,039, I $1 / 6 / 43$, p. 474.)

384 I108I G.B. ... ... Stress Due to Collapse of Vapour Bubbles in a Liquid. (M. Reiner, Engineering, Vol. I55, No. $4,038,4 / 6 / 43$, p. 454 .)

385 III66 G.B. .

Stress Due to the Collapse of Vapour Bubbles in a Liquid. (V. R. Evans, Engineering, Vol. ' 55 , No. 4,040 , $18 / 6 / 43$, p. 494 .)

386 11167. G.B. ... ... Cracking of Loads Under Tensile Load. (G. Roberts, Engineering, Vol. I55, No. 4,040, 18/6/43, p. 495.)

387 11228 G.B. ... ... A Note on Stress Systems in Aeleotropic Materials $-I$ and II. (A. E. Green, Phil. Mag., Vol. 34, No. 233, June, r943, pp. 416-422.)

$388 \quad 11425$ Germany

Influence of Non-Uniform Stress Distribution on the Strength of Materials. (W. Kunzle, Symposium of Papers on the Elements of Machine Design (Aachen), I935, pp. 3-16.)

38911426 Germany ... Example of Modern Stress Calculation. (E. Lehr, Symposium of Papers on the Elements of Machine Design (Aachen), 1935, pp. 17-23.)

39011427 Germany ... Model Experiments on Stress Distribution in Section Undergoing Torsion and Discussion. (W. Bautz, Symposium of Papers on the Elements of Machine Design (Aachen), 1935, pp. 23-27 and 28-33.)

Strength of Wooden Beams, etc.

391 10843 Switzerland ... Strength Investigations on Spiral Diffusions. (F. Salzmann and A. Suss, Escher Wyss, No. 15-16, 1942-1943, pp. 164-169.)

39211029 G.B. ... ... Structure and Breaking Strength of Plastic Mouldings (from Schweizer Archiv., 1943, No. 9, p. 55.) (G. O. Grimm, Vol. 7, No. 73, June, 1943, pp. 251-257.)

393 Iro89 Germany ... Strength Characteristics of Some Wooden Structural Elements Taken from Captured Russian Aircraft. (J. T. Heiner, Luftwissen, Vol. 1o, No. 4, April, 1943, pp. 103-104.)

394 I 262 U.S.A. ... Bending Strength in the Plastic Range. (F. P. Cozzone, J. of Aeron. Sci., Vol. 1o, No. 5, 1943, pp. I37-1 5 .)

395 II574 Germany ... Stress Distribution in Thin Walled Conical Beams. (A. Pfluger, Z.A.M.M., Vol. 22, No. 2, April, 1942, pp. 99-116.)

397 11682 G.B. ... ... The Strength of Timber Beams. (Mech. World, Vol. I I 4 , No. 2,949, 9/7/43, pp. 35-36.) 
ITEM
NO.T.P.
REF.

Photo-Elasticity

398 ro73I U.S.A. ... The Fundamentals of Photo-Elastic Stress Ana lysis Applied to Dynamic Stresses. (W. N. Findley, Eastern Photo-Elasticity Conference, $9^{\text {th }}$ Semi-Annual Meeting, I3/5/39, pp. I-I I.)

399 I0732 U.S.A. $\quad$.. Gelatin Models. (T. R. Cuykendall, Eastern PhotoElasticity Conference, 9th Semi-Annual Meeting, 13/5/39, pp. I3-I 5.)

$400 \quad$ I0733 U.S.A. $\quad$... Three Dimensional Photo-Elastic Analysis by Scattered Light. (R. Weller, Eastern Photo-Elasticity Conference, 9 th Semi-Annual Meeting, 13/5/39, pp. 19-21.)

$401 \quad 10734$ U.S.A. ... Preparation of Photo-Elastic Models. (M. L. Price, Eastern Photo-Elasticity Conference, 9th SemiAnnual Meeting, 13/5/39, pp. 23-26.)

$402 \quad 11085$ U.S.A.

Theory of Large Elastic Deformations (Rubber). (L. R. G. Treloar, Nature, Vol. 15 I, No. 3,839, 29/5/43, p. 6r6.)

403 III45 G.B. ...

Seeing Strains and Stresses Inside all Material with "Photo-Elasticity." (British Plastics, Vol. I5, No. I69, June, 1942, pp. I8-20.)

Creep Tests.

404 I0674 G.B. ... ... Precision in Creep Testing. (J. H. Fellows and others, Metals Technology, Aug., 1942, pp. 1-15.) (Met. Vick. Tech. News Bull., No. $837,23 / 10 / 42$, p. 5.)

40510725 U.S.A. $\quad$.. Report on Tubular Creep Tests (Internal Pressure). (F. H. Norton and C. R. Soldberg, Trans. A.S.M.E., Vol. 64, No. 8, Nov., 1942, pp. 769-777.)

40610828 U.S.A. $\quad \ldots \quad$ I00,000 Hours Creep Tests on Alloy Steels. (Sci. Am., Vol. 168, No. 2, Feb., 1943, p. 61.)

407 I 300 G.B. ...

Creep Resistance of Superheater Tube Steels in Tube and Bar Form. (J. A. Jones and W. E. Bardgett, Engineer, Vol. I 76 , No. 4,564, 2/7/43, pp. 6-8.)

\section{Fatigue Tests.}

40810682 G.B. ... $\quad \ldots$ Behaviour of Spot Welds Under Fatigue Stres8. (A. M. Unger and others, Weld. J., March, I942, $p p$. 1,355-1,425.) (Met. Vick. Tech. News Bull., No. $864,30 / 4 / 43$, p. 2.)

40910960 G.B. ... ... Fatigue Tests on Some Copper Alloys. (H. R. Anderson and C. S. Smith, Engineering Inspection, Vol. 7, No. 2, April-June, 1942, pp. 15-21.)

410 II254 U.S.A. ... Fatigue Failures in Common Machine Parts. (J. O. Almen, Metal Progress, Vol. 43, No. 5, May, 1943, pp. 737-740.)

\section{MATERIALS (PROPERTIES, FABRICATION, INSPECTION).}

\section{A. Properties.}

Al. and Mg. Alloys.

4II 10759 G.B. ... ... The Properties of Various Wrought Al. Alloys. (Autom. Eng., Vol. 33, No. 435, April, 1943, pp. $145^{-1} 4^{6 .)}$ 
ITEM R.T.P.

No. REF.

412 10899 Germany

413 Jog22 Japan

414 I0923 Japan

$415 \quad 11287$ G.B. ...

$4 I 6$ II304 G.B. ...

417 II4I7 G.B. ...

$418 \quad 11656$ U.S.A.

$4191077^{8}$ U.S.A.

420 I0780 U.S.A.

$421 \quad 107^{82}$ U.S.A.

42210965 G.B. ..

423 I 1008 U.S.A.

424 I IOI I U.S.A.

42511012 U.S.A.

426 Iror4 U.S.A.

427 I 1076 G.B. .

$428 \quad 11248$ U.S.A.

429 I1249 U.S.A.
TITLE AND JOURNAL.

The Strength of Al.-Mg. Alloys at the Temperature of Liquid Oxygen (from Zeitschrift für die gesamte Kälte-Industrie, Vol. 49, No. 6, 1942, pp. 71-72). (H. Maeder, Eng. Digest, Vol. 4, No. 1, Jan., 1943, pp. IO-II.)

A New Magnesium Alloy. (Inter. Avia., No. 856857, I $5 / 2 / 43$, p. Io.)

Al. and $M g$. Production in Japan. (Inter. Avia., No. $856-857$, I $5 / 2 / 43$, p. II.)

Protective Treatment of Magnesium Alloys. (Metal Industry, Vol. 63, No. I, 2/7/43, p. 8.)

Aluminium in Post-War Reconstruction-I. (R. Hammond, Engineer, Vol. I76, No. 4,564, 2/7/43, pp. I 5-16.)

Metallographic Technique for Magnesium Alloys. (F. A. Fox and H. T. Hall, Metal Industry, Vol. 62, No. 25, I8/6/43, pp. 391-392.)

... High Strength Natural Ageing Al. Alloy. (H. Brown, Aero Digest, Vol. 42, No. 5, May, 1943, pp. 209-210, 296 and 333.)

\section{Iron and Steel.}

Sources of Hydrogen in Steel and Means for its Elimination. (C. H. Zapffe, Metal Progress, Vol. 43, No. 3, March, 1943, pp. 397-40r.)

Weldability of N.E. 1,330 and N.E. I,335 (Laboratory Tests). (O. E. Harder and C. B. Voldrich, Metal Progress, Vol. 43, No. 3, March, 1943, pp. 409-410.)

Properties of Important Wrought Chromium Nickel-Iron Alloys (Data. Sheet). (Metal Progress, Vol. 43, No. 3, March, 1943, p. 41 2a.)

The Interpretation of Steel Specifications. (E. Gregory, Engineering Inspection, Vol. 7, No. 3, Autumn, 1942, pp. 4-7.)

.. Machinability of National Alloy Steels. (O. W. Boston, Metal Progress, Vol. 43, No. 4, April, 1943, p. 543.)

... Tests on N.E. 8,63o Steels for Welded Air Frames. (M. Hill, Metal Progress, Vol. 43, No. 4, April, 1943, pp. 555-559.)

.. Properties of Important Wrought Chromium-Iron Alloy (Data Sheet). (Metal Progress, Vol. 43, No. 4, April, 1943, p. 560a.)

.. Under-Hardening of Steel-Possible Applications. (Metal Progress, Vol. 43, No. 4, April, 1943, p. 570.)

.. Research on Cast Iron. (Engineering, Vol. I55, No. $4,038,4 / 6 / 43$, p. 445 .)

Aluminium Covered Sheet Steel. (Sci. Am., Vol. 168, No. 6, June, 1943, p. 279.)

National Emergency Steels (N.E. 1,300 Series). (Metal Progress, Vol. 43, No. 5, pp. 7 I I-715.) 
ITEM R.T.P.

No. REF.

$43^{\circ}$ I 1253 U.S.A.

$43^{1} \quad 10777$ U.S.A.

$43^{2} 10780$ U.S.A.

43310808 Germany

434 10977 G.B. ...

43510980 G.B. ...

436 r тог9 U.S.A.

43711064 G.B.

$43^{8} \quad$ III62 U.S.A.

$439 \pm 1232$ G.B.

440 II 286 G.B. ...

$44 \mathrm{I}$ II605 U.S.A.

$44^{2} \quad 10614$ G.B. ...

44310621 Germany

$4441065^{\circ}$ G.B. . .

44510693 G.B. ...

446 10701 G.B. ...

$447 \quad$ I0829 U.S.A.

$448 \quad 1083^{I} \quad$ U.S.A.
TITLE AND JOURNAL.

Mechanical Properties of N.E., S.A.E., and Other Hardened Steels. (W. G. Patton, Metal Progress, Vol. 43, No. 5, May, 1943, pp. 726-733.)

Non-Ferrous Metals.

Substitute for go Cu., so Sn. Bearings. (M. F. Garwood and E. H. Stilwill, Metal Progress, Vol. 43, No. 3, March, 1943, p. 396.)

Down Grading Chart for Brass and Bronze Castings. (C. S. Cole, Metal Progress, Vol. 43, No. 3, March, 1943, pp. 406-408.)

German Copper Shortage. (Flight, Vol. 43, No. $1,793,6 / 5 / 43$, p. 480 .)

The Uses of Lead in Wartime. (Metal Industry, Vol. 62, No. 23, 4/6/43, p. 353.)

Ingot Brass and Bronze. (W. Romanoff, Metal Industry, Vol. 62, No. 23, 4/6/43, pp. 357-358.)

Influence of Cast Structure on Mechanical Properties of Non-Ferrous Alloys. (Metal Progress, Vol. 43, No. 4, April, I943, pp. 586-59o.)

Zinc Loss in Brass. (Metal Industry, Vol. 62, No. 24, I $1 / 6 / 43$, p. 374.)

Physical Properties and Thermal Treatment of $K$. Monel. (Review of Sci. Insts., Vol. 14, No. 3, March, I943, p. 82.)

Sources and Uses of Beryllium. (Engineering, Vol. 156 , No. $4,042,2 / 7 / 43$, p. 10.)

Non-Ferrous Secondary Metals. (F. W. Willard, Metal Industry, Vol. 63, No. I, 2 July, 1943, pp. 6-8.)

Thermal Expansion of Bronzes (Tin-Zinc, Leaded, Aluminium and Silicon Bronzes). (P. Hidnert, J. Res. Bur. Stands., Vol. 30, No. I, Jan., 1943, pp. 75-88.)

\section{Plastics and Resins.}

Manufacturing Technique for Plastic Materials. (Aircraft Production, Vol. 5, No. 56, June, 1943, pp. 299-301.)

German Production of Artificial Fibre. (Flight, Vol. 43 , No. $1,795,20 / 5 / 43$, p. 520.)

Plastic Panels and Dials. (Aeroplane, Vol. 64, No. $1,669,21 / 5 / 43$, p. 602.)

Acrylate and Vinyl Chloride Resin Dispersion. (A. Renfrew and C. F. Flint, Ind. Chem., April, 1943, pp. I94-198.) (Met. Vick. Tech. News

Bull., No. $863,23 / 4 / 43$, p. 9.)
Paper Condensers. (M. Brotherton, Bell Laboratory Record, Jan., 1943, pp. 123-126.) (Met. Vick. Tech. News Bull., No. $859,26 / 3 / 43$, p. 8.)

Flame Proof Plastic Laminated Cotton Cloth (Light Weight). (Sci. Am., Vol. 168, No. 2, Feb., 1943, p. 62.)

Lignum Insulating Material from Paper Waste. (Sci. Am., Vol. 168, No. 2, Feb., 1943, pp. 84-85.) 
ITEM R.T.P.

No. REF.

449 Iogo4 Germany

45011026 G.B. .

$45^{\mathrm{I}}$ I 1027 G.B.

45211028 G.B. ..

453 I 103I Germany

454

I 1036 G.B. ...

455

II043 G.B. ...

$45^{6} \times 105^{\circ}$ U.S.A.

457 1 1060 U.S.A

$45^{8}$ III43 G.B. ..

$459 \simeq 1144$ G.B. ..

$460 \times 1146$ G.B. ...

$46 r \quad 11148$ G.B. . .

462 III49 G.B. ...

$463 \quad 11152 \quad$ U.S.A.

$464 \quad I 154$ U.S.A.

465 III56 G.B. ...

466 I1160 U.S.A.

$467 \quad$ I117 $\quad$ U.S.A.

$468 \quad$ III87 U.S.A.

46911243 U.S.A.
TITLE AND JOURNAL.

Strength of Plastic Mouldings from Composite Materials (from Kunststoffe, Vol. 32, No. 1, Jan., 1942, pp. 1-9.) (H. R. Jacobi, Eng. Digest, Vol. 4, No. 1, Jan., 1943, pp. 21-24.)

Metalizing Plastics. (E. E. Halls, Plastics, Vol. 7, No. 73, June, 1943, pp. 235-243.)

Spraying of Plastics. (Plastics, Vol. 7, No. 73, June, 1943, p. 243.)

Synthetic Resins Used in the Mosquito. (Plastics, Vol. 7, No. 73, June, 1943, p. 246.)

Sawing of Laminated Plastics (from Der Betrieb, Aug., 1942). (Plastics, Vol. 7, No. 73, June, 1943, p. 258.)

Resinoids and Other Plastics as Film Formers. XIX-Electrolyte Aspects of High Polymeric Systems. (B. J. Brajnikoff, Plastics, Vol. 7, No. 73, June, 1943, pp. 268-276.)

The Practical Use of Plastics in Building and Structural Work. (Chem. and Ind., Vol. 62, No. 24, I 2/6/43, p. 226.)

Coal as Raw Material for Plastics, etc. (J. K. Hunt, Sci. Am., Vol. I68, No. 5, May, I943, pp. 196-198.)

Soybean Plastics. (Sci. Am., Vol. I68, No. 5, May, I943, p. 221.)

Heatronic Moulding-A New Technique for Rapid Moulding of Thermo-Setting Plastics. (V. E. Meharg, British Plastics, Vol. I5, No. I69, June, 1942, pp. 6-13.)

Plastics in the Services. (British Plastics, Vol. 15 , No. i69, June, 1942, pp. 14-17.)

Plastics in Surgery. (British Plastics, Vol. I $_{5}$, No. I69, June, I942, p. 22.)

Machinery for "Igelit" Resins. (British Plastics, Vol I5, No. 169, June, 1943, p. 28 .)

New Plastics to Make Dies, Jigs and Forming Blocks. (British Plastics, Vol. I5, No. I69, June, 1943, p. 29.)

Position of Different Type Plastics in U.S.A. (British Plastics, Vol. I 5, No. I69, June, I943, pp. 40 and 5o.)

Saflex-Coated Fabric. (C. T. King, British Plastics, Vol. I5, No. I69, pp. 43-45.)

Plastic Hinges Used in the U.S. Army. (British Plastics, Vol. 15, No. 169, June, 1943, p. 50.)

Extruded Plastic Tubing for Insulators and Wire Markers. (Review of Sci. Insts., Vol. 14, No. 3, March, 1943, pp. 8I-82.)

Plastic Fuse. (Ind. and Eng. Chem. (News Ed.), 10/5/43, p. 706.)

Drill Jig Made of Durez Casting Resin. (Autom. Ind., Vol. 88, No. $7,1 / 4 / 43$, p. 43.)

Thermo Plastic for Dies and Jigs. (Sci. Am., Vol. I68, No. 6, June, 1943, pp. 254-255.) 
ITEM R.T.P.

No. REF.

TITLE AND JOURNAL.

$470 \quad$ I 589 G.B. . .

Practical Use of Plastics in Building and Structural Work. (Plastics, Vol. 7, No. 74, July, 1943, p. 286.)

47 I I 590 Germany

Routine Working of Polyvinyl Chloride and Polyisobutylene. (Digest of Kunststoffe, Vol. 32, p. 307, 1942.) (Klant, Plastics, Vol. 7, No.' 74, July, 1943, pp. 287-291.)

$47^{2}$ II592 Germany ... Curing of Synthetic Resin Wood Adhesives by Resistance Heating. (Mitt d. Fachausschusses für Holzfragen, No. 29, 194I, pp. 65-84.) (Egner, Plastics, Vol. 7, No. 74, July, 1943, p. 293.)

47311699 U.S.A. $\quad$.. Plastics from Redwoods. (H. F. Lewis, A.S.M.E. Preprint, April 26-28, 1943.)

Rubber (Nat. and Syn.).

474 ro76r G.B. ... ... Rubber Mouldings (Relt Mouldings). (Autom.

Eng., Vol. 33, No. 435, April, 1943, p. 154.)

47510809 Germany ... Rubber Yielding Plants to Increase German Rubber Supply. (Flight, Vol. 43, No. 1,793, $6 / 5 / 43$, p. 480 .)

47610864 U.S.A. $\quad$... U.S. Natural Rubber Production Programme. (Sci. Am., Vol. 168, No. 4, April, 1943, pp. 172-173.)

477 III47 G.B. ...

A New Rubber Substitute (from Soya Bean). (British Plastics, Vol. I5, No. I69, June, I943, p. 24.)

478 III58 U.S.A. _.. Machining Rubber on a Lathe. (S. A. Weissenburger, Rev. of Sci. Insts., Vol. 14, No. 3, March, 1943, p. 77.)

479 III64 G.B. .

Modern Synthetic Rubber (Book Review). Barron, Engineering, Vol. I55, No. 4,040, I8/6/43, p. 483.)

480 II 4 IO U.S.A.

A New Type of Synthetic Rubber (Witcogum). (Ind. and Eng. Chem., Vol. 21, No. 8, 25/4/43, p. 560.)

48I 11593 G.B. ... ... Resistance of Neoprene to Various Refrigerating Agents. (Lawrence, Plastics, Vol. 7, No. 74, July, 1943, pp. 293-294.)

482 I 1606 U.S.A.

Synthetic Rubber-Survey. (H. L. Fisher, Industrial Engineering and Chem. (News Ed.), Vol. 2 I, No. 10, 25/5/43, pp. 741-750.)

483 Iт61 U.S.A. ... Synthetic Rubber for Balloons. (Ind. and Eng. Chem. (News Ed.), Vol. 21, No. 10, 25/5/43, p. 782 .)

484 I 1619 U.S.A. _. Hydraulic Efficiency of Rubber Pads. (W. Tucker, Aviation, Vol. 42, No. 5, May, I943, pp. 167-169 and 360 .)

485 II740 G.B. ... ... Compounding Natural and Synthetic Rubbers to Resist Low Temperatures. (The Services Rubber Investigations, Manufacturers' Memorandum No. M.5.)

\section{Wood and Plywood.}

486 ro694 G.B. ... ... The Characteristics of Bakelised Wood. (A. E. L. Jervis, Electrical Times, 15/4/43, pp. 428-43r.) (Met. Vick. Tech. News Bull., No. $863,23 / 4 / 43$, p. IO.) 
ITEM R.T.P.

No. REF.

TITLE AND JOURNAL.

487 I0849 U.S.A.

Fatigue Characteristics of Natural and Resin. Impregnated, Compressed, Laminated Woods. (F. B. Fuller and T. T. Oberg, J. Aeron. Sci., Vol. Io, No. 3, March, I943, pp. 8I-85.)

488 ro858 U.S.A. ... New Bonded Plywood (Compregwood). (Sci. American, Vol. I68, No. 4, April, 1943, pp. I.57-158.)

489 Iog68 G.B. ... ... Tests of Glued Laminated Wood Beams Impregnated with Creosote. (W. A. Oliver, Engineering Inspection, Vol. 7, No. 3, Autumn, I942, pp. 16-22.)

$490 \quad$ I 1037 G.B. . .

Plywood Motor Car Body (Photo). (Plastics, Vol. 7, No. 73, June, 1943, p. 276.)

$491 \quad 11058$ U.S.A.

Dye Made by Chemical Treatment of Sawdust. (Sci. Am., Vol. 168, No. 5, May, 1943, pp. 223-224.)

492 III5I G.B. .

The Importance of Moisture Content in Wood.

(British Plastics, Vol. I5, No. I69, June, I943, p. 27.)

$\begin{array}{lll}493 & \text { I1217 } & \text { G.B. . } \\ 494 & \text { II259 } & \text { U.S.A. } \\ 495 & \text { I } 1306 & \text { U.S.A. } \\ 496 & \text { II } 478 & \text { U.S.A. } \\ 497 & \text { II704 } & \text { U.S.A. }\end{array}$

dentification of Indian Timbers. (Nature, Vol. I 51, No. 3,841, I 2/6/43, p. 669.)

Timber for Photomicrography. (Metal Progress, Vol. 43, No. 5, May, I943, p. 747.)

Prefabricated Plywood and Timber-I. Beam to Replace Steel ("Timbeam"). (Engineer, Vol. I 76 , No. $4,564,2 / 7 / 43$, p. 19.) Types of American Plywoods. (Inter. Avia., No. 867, I $/ 5 / 43$, p. I 8 .)

Some Observations on Density and Shrinkage of Ponderosa Pine Wood. (R. A. Cockrell, A.S.M.E. Preprint, April 26-28, 1943.)

\section{Diamonds, Glass Ceramics.}

$49810860 \quad$ U.S.A.

Diamond-Charged Lens Grinding Tools for Precision Optics. (Sci. American, Vol. I68, No. 4, April, 1943, p. I 59.)

499 II033 G.B. ...

Insulating Media for Conduit and Cable (from Schweizer Archiv., No. 9, p. 37, 1943). (Plastics, Vol. 7, No. 73, June, 1943, p. 259.)

500 11034 Germany ... Safety Glass Intermediate (from Kolloid Z., Vol. 98, pp. I I 7 and 376). (Plastics, Vol. 7, No. 73, June, I943, p. 259.)

50I I I04I G.B. ... ... Foam Glass. (Engineer, No. I75, No. 4,561, I $1 / 6 / 43$, p. 476 .)

502 I 1080 G.B. ... ... Glass Fabric for Electrical Insulation. (Engineering, Vol. I 55, No. 4,038, 4/6/43, p. 452.)

503 I I 16 I U.S.A.

$504 \Upsilon 1244$ U.S.A.

New Compact Ceramic Condenser. (Rev. of Sci. Insts., Vol. I4, No. 3, March, I943, pp. 81-82.) New Glass Process for Complicated Insulators (Cold Moulding followed by Fusing). (Sci. Am., Vol. 168, No. 6, June, 1943, p. 255.)

505 I 3337 Germany ... Plexiglass-Properties and Fabrication (Ref. Sheet No. 7-8). (Flugsport, Vol. 35, No. 9, 19/5/43, pp. I $12 \mathbf{2 a - b . )}$ 


\begin{tabular}{|c|c|c|}
\hline $\begin{array}{l}\text { ITEM } \\
\text { NO. }\end{array}$ & & $\begin{array}{l}\text { T.P. } \\
\text { EF. }\end{array}$ \\
\hline 506 & 11407 & U.S.A. \\
\hline 507 & I I 564 & U.S.A. \\
\hline 508 & I I 586 & U.S.A. \\
\hline 509 & I I 587 & U.S.A. \\
\hline $5^{10}$ & 11596 & Germany \\
\hline $5^{11}$ & 11004 & U.S.A. \\
\hline $5^{12}$ & 11065 & G.B. $\ldots$ \\
\hline & I I 41 & G.B. \\
\hline
\end{tabular}

TITLE AND JOURNAL.

... Extending the Life of Chemical Glassware. (E. J. Lewis, Ind. and Eng. Chem., Vol. 21, No. 8, 25/4/43, pp. 552-554.)

Glass Jewels for Instrument Bearings. (Rev. of Sci. Instrum., Vol. I4, No. 4, April, 1943, p. I 2 I.)

A Ceramic "Replacement" Material (Prestite). (Rev. of Sci. Instrum., Vol. 14, No. 5, May, 1943, p. I 55.)

Multiform Glassware for Electrical Insulator. (Rev. of Sci. Instruments, Vol. 14, No. 5, May, 1943,

pp. ${ }^{155-156 .)}$
Course of Fracture in Plexiglass. (Z. Techn. Physik., Vol. 21, 1940, p. 393.) (Elle and Smith, Plastics, Vol. 7, No. 74, July, 1943, p. 294.)

\section{Solders and Bearing Materials.}

.. Bearing Alloys with Low Tin Content. (Autom. Ind., Vol. 88, No. 6, 15/3/43, p. I 86.)

Tin Conserving Solders. (G. F. Read, Metal Industry, Vol. 62, No. 24, I $16 / 43$, pp. 375-377.)

Lead-Arsenic - Antimony Soft Solder. (R. L. Dowdell and others, Metal Industry, Vol. 62, No. $25,18 / 6 / 42$, pp. 389-39o.)

5 I4 II42I G.B. ...

Brazing and Soldering. (R. N. Chaplin, Metal Industry, Vol. 62 , No. 25, 18/6/43, p. 395.)

Miscellaneous (Cements, Varnishes, etc.).

$5^{1} 510708$ G.B. ...

Heat-Setting Varnishes. (S. L. Moses, Railway Elect. Eng., Dec., 1942, pp. 263-266 and 281.) (Met. Vick. Tech. News Bull., No. 854, 19/2/43, p. 9.)

$5^{16} \quad 1075^{8}$ G.B. ...

Heat Sensitive Crayons. (Autom. Eng., Vol. 33, No. 435, April, 1943, p. 136.)

$5^{17} \quad 1^{1076} 3$ G.B. ...

Cemented Carbides (Review of Development). (Autom. Eng., Vol. 33, No. 435, April, 1943, pp. 161-164.)

$5^{18} \quad 10859$ U.S.A.

Corrugated Asphalt Siding to Replace Corrugated Steel. (Sci. Amer., Vol. I68, No. 4, April, I943, p. I 59.)

$\begin{array}{lrl}5^{19} & \text { I1077 } & \text { Canada } \\ 5^{20} & \text { III53 } & \text { U.S.A. } \\ 5^{21} & \text { II234 } & \text { G.B. . . } \\ 5^{22} & \text { II277 } & \text { G.B. . . }\end{array}$

Canadian War-Time Concrete Pavements. (Engineering, Vol. I 55, No. 4,०38, 4/6/43, p. 446.)

Extensive Use of Casein Glues in U.S.A. (British Plastics, Vol. I 5, No. I69, June, 1943, p. 42.)

Concrete Pavings in Low Temperatures. (Engineering, Vol. I 56, No. 4,042, 2/7/43, pp. 16-I 7.)

Three-Pin Reinforced Concrete Frame Buildings. (Engineering, Vol. I 55, No. 4,04I, 25/6/43, pp. 506-507.)

523 II290 G.B. ...

Plaster-Asbestos Moulds. (Metal Industry, Vol. 63. No. 1, 2/7/43, p. 9.)

$524 \quad 115^{84}$ U.S.A.

A New Laboratory Cement. (Rev. of Sci. Instrum., Vol. 14, No. 5, May, 1943, p. I 54.)

$\mathbf{5 2 5}$ I I594 Germany

Lacquered Wire in Telephone Engineering (from Electr. Nachs. Techn., 1941, Vol. 18.) (Wolff and Pohler, Plastics, Vol. 7, No. 74, July, I943, p. 294.) 
ITEM

No. R.T.P.

REF.

TITLE AND JOURNAL.

\section{B. Fabrication.}

Welding.

$5^{26} \quad 10676$ G.B. ... ... Stud Welding System. (A. M. Candy, Welding Journal, Aug., 1942, pp. 509-512.) (Met. Vick. Tech. News Bull., No. $837,23 / 10 / 42$, p. 8.)

$527 \quad 10677$ G.B. .

Redesign of Cast Iron Machine Parts for Welding Construction Reasons and Principles. (F. Koenigsberger, Welder, Jan.-June, 1942, pp. 266-269.) (Met. Vick. Tech. News Bull., No. $837,23 / 10 / 42$, p. 9.)

52810678 G.B. ... ... Proposed Specifications for Stainless Steel Arc Welding Electrodes for Welding Steels of High Hardenability. (Welding Journal, Aug., 1942, pp. 513-514.) (Met. Vick. Tech. News Bull., No. $837,23 / 10 / 42$, p. II.)

52910679 G.B. .

Arc Welding Aircraft Tubing. (Welding Engineer, Aug., 1942, pp. 35-37.) (Met. Vick. Tech. News Bull., No. $837,23 / 10 / 43$, p. 12.)

$530 \quad 10680$ G.B. ... ... Current Measurement Improves Welding Technique -Pt. II. (C. M. Manyer and H. S. Day, Welding Eng., Aug., 1942, pp. 39-4I.) (Met. Vick. Tech. News Bull., No. 837, 23/10/43, p. 12.)

531 I068I G.B. ...

Metallic Arc Welding of Copper Pressure Vessels. (G. H. Sandberg, Welding Journal, Aug., I942, pp. 507-509.) (Met. Vick. Tech. News Bull., No. $837,23 / 10 / 42$, p. 7.$)$

53210689 G.B. ... ... New Stud Welding Process. (Welding Engineer, Dec., I942, p. 42.) (Met. Vick. Tech. News Bull., No. $85^{6}, 5 / 3 / 43$, p. 3 .)

53310690 G. B. . Welding of Stainless Steel. (S. L. Rich, Welding J., June, 1942, pp. 293S-296S.) (Met. Vick. Tech. News Bull., No. $856,5 / 3 / 43$, p. 4.)

53410691 G.B. . .

Device for Measuring Tip Force and Current in Spot Welding. (H. Wolfe and R. W. Powell, Welding Journal, June, 1942, pp. 293S-296S.) (Met. Vick. Tech. News Bull., No. $856,5 / 3 / 43$, p. 4.)

53510692 G.B. .

Clad Steel "Sandwiches" welded by the Carbon Arc. (T. S. Fitch and L. W. Townsend, Iron Age, I8/2/43, pp. 54-59.) (Met. Vick. Tech. News Bull., No. $863,23 / 4 / 43$, p. 8.)

536 10707. G.B. ... ... Welding by Unionmelt Process. (Westinghouse Engineer, Nov., 1942, pp. 1 26-1 28.) (Met. Vick. Tech. News Bull., No. $854,19 / 2 / 43$, p. 6.)

53710769 G.B. ... ... The Reclamation of Cutting Tools by Arc Welding. (J. R. Treadwell, Machinery, Vol. 62, No. I,595, 6/5/43, pp. 494-496.)

53810814 Germany ... The Gussolite Process for the Temperature Welding of Cast Iron. (Welding Industry, Vol. 2, No. 5, June, 1934, pp. 163-165.)

539 1102I U.S.A. ... World's Largest Machine for Spot Welding Aluminium. (Metal Progress, Vol. 43, No. 4, April, 1943, p. 6r6.) 
No. REF.

TITLE AND JOURNAL.

$540 \quad 11078$ G.B. .

... Structural Design of Welded Hulls. (J. Turnbull, Engineering, Vol. I55, No. 4, ${ }_{3} 8,4 / 6 / 43$, pp. 447-448.)

54I III50 G.B. ... ... Spot Welding with Glue. (British Plastics, Vol.

542 II24I U.S.A. I5, No. I69, June, 1943, p. 27.)

$\begin{array}{lll}543 & \text { I1267 } & \text { U.S.A. } \\ 544 & \text { I1296 } & \text { G.B. ... } \\ & & \\ 545 & 1087^{2} & \text { U.S.A. } \\ 546 & 10979 & \text { G.B. ... } \\ 547 & 11006 & \text { U.S.A. } \\ 548 & 11030 & \text { Germany } \\ 549 & 11066 & \text { G.B. ... } \\ 55^{\circ} & \text { I1172 } & \text { U.S.A. }\end{array}$
Magnesium Welding with the Helium Arc. (S. R.
Winter, Scientific American, Vol. I68, No. 6,
Magnesium Welding with the Helium Arc. (S. R.
Winter, Scientific American, Vol. I68, No. 6, June, 1943, pp. 252-254.)

Shipyard Layout for Welded Construction. (Engineer, Vol. I 75 , No. $4,563,25 / 6 / 43$, pp. 504-505.)

... Removing Welding Flux from Aluminium. (Metal Industry, Vol. 62, No. 26, 25/6/43, p. 406.)

Surface Treatment (Plating, etc.).

... Surbrite-A New Steel Surface Conditioner. (Sci. Am., Vol. 168, No. 4, April, 1943, p. 185.)

Metal Spraying and New Surface Roughening Tool. (Metal Industry, Vol. 62, No. 3, 4/6/43, p. 356.)

... Improvement in the Electrolytic Tinplating Process. (Autom. Ind., Vol. 88, No. 6, 15/3/43, p.

\section{6.)}

.. Protective Lacquers for Zinc (from the German). (Plastics, Vol. 7, No. 73, June, 1943, p. 258.)

.. Black Nickel Deposition. (E. Schore, Metal Industry, Vol. 62, No. 24, II $/ 6 / 43$, pp. 378-380.)

$55^{\circ}$ II172 U.S.A.

$55^{\mathrm{I}}$ II255 U.S.A.

$55^{2}$ I 297 U.S.A.

New Phosphating Treatment (Pre-Treatment with Disoduin Phosphate Containing Traces of Titanium). (F. W. Van Antwerpen, Ind. and Eng. Chem. (News Ed.), Vol. 21, No. 9, 10/5/43, pp. 7 IO-7II.)

Electroplating Metals (Data Sheet). (Metal Progress, Vol. 43, No. 5, May, I943, p. 74I.)

Recent Developments in Zinc Plating. (M. B. Diggin, Metal Industry, Vol. 62, No. 26, 25/6/43, pp. 407-410.)

\section{Surface Finish (Polishing, etc.).}

55310722 U.S.A.

The Foren Mill for Rolling Seamless Tubes. (E. W. Wrage, Trans. A.S.M.E., Vol. 64, No. 8, Nov., I942, pp. 745-751.)

55410823 G.B. ... … Surface Finish and the Function of Parts (Discussion). (G. Schlesinger, Engineering, Vol. I55, No. $4,03 \mathrm{I}, 28 / 5 / 43$, p. 434 .)

555 11038 G.B. ... ... Surface. Finish and Function of Parts. (G. Schlesinger, Engineer, Vol. 175, No. 4,561, I I $/ 6 / 43$, pp. 466-467.)

556 I 1044 G.B. ... ... Surface Finish and the Function of Parts. (G. S. Schlesinger, Engineering, Vol. I 55, No. 4,039, I I $6 / 43$, pp. $464-465$ and $478-480$.)

557 I 1062 Germany ... Rolling Mills for Light Metals. (Translation from "Aluminium," Vol. 24, No. 5, 1942, pp. I6r-I65.) (W. Kramer, Metal Industry, Vol. 62, No. 24, I $/ 6 / 43$, pp. 370-372.)

$55^{8} 11082$ G.B. ... ... Surface Finish and the Function of Parts (Contd.). (G. Schlesinger, Engineering, Vol. I 55, No. $4,038,4 / 6 / 43$, pp. $454-455$ and $45^{8-460}$.) 
TITLES AND REFERENCES OF ARTICLES AND PAPGRS.

ITEM , R.T.P.

No. REF.

TITLE AND JOURNAL.

5591198 G.B. ...

... Surface Finish and the Function of Parts. (G. Schlesinger, Engineering, Vol. I55, No. 4,040, r 8/6/43, pp. 498-499.)

560 11169 G.B. ... ... Electrolytic Polishing of Metals. (S. Wernick, Chem. and Ind., Vol. 62, No. 26, 26/6/43, pp. 238-243.)

$561 \quad$ I 1256 U.S.A.

A Versatile Metallographic Polishing Process. (M. Ferguson, Metal Progress, Vol. 43, No. 5, May, I943, pp. 743-744.)

$562 \quad$ II 288 G. B. ..

Polishing, Buffing and Burring. (H. J. McAlees, Metal Industry, Vol. 63, No. I, July 2, 1943, p. 9.)

563 Ir291 Germany ... Developments in Rolling Light Metals. (Alu-

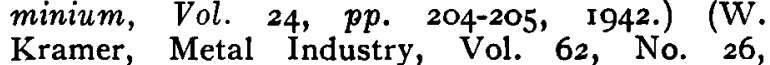
25/6/42, pp. 402-403.)

564 II292 G.B. ..

Developments in Grinding and Polishing. (Metal Industry, Vol. 62, No. 26, 25/6/43, p. 403.)

565 II 428 G.B. ...

Surface Finish and the Function of Parts.

(G. Schlesinger, Preprint of Paper Read at the Inst. of Mech. Engs., 21/5/1943.)

Heat Treatment.

56610768 G.B. ..

Electric Furnace Brazing Technique. (Machinery, Vol. 62, No. I,595, 6/5/43, pp. 488-49I.)

$567 \quad 1085^{\circ}$ U.S.A.

Effect of Cold Worl and Heat Treatment on 24 St. Aluminium Alloy. (B. Mitchell, J. Aeronautical Sci., Vol. Io, No. 3, March, 1943, pp. 86-90.)

56810906 G.B. ... Iodine and Potassium Chloride from. Metallic Dust from Blast Furnaces. (P. Dicken and W. Middel, Eng. Digest, Vol. 4, No. I, Jan., 1943, pp. 27-3o.)

569 r 1015 U.S.A.

Decarburized Zones. (Metal Progress, Vol. 43, No. 4, April, 1943, pp. 570-57I.)

$570 \quad 11016$ U.S.A.

Converting Semi-Muffle Furnace to Full Muffe Type. (Metal Progress, Vol. 43, No. 4, April, 1943, pp. 571-572.)

57111020 U.S.A. ... Calibration of Platinum Thermocouple at Steel Melting Range. (Metal Progress, Vol. 43, No. 4, April, 1943, pp. 598-600.)

572 I 1067 G.B. .

Heat Treatment of Non-Ferrous Alloys. (Metal Industry, Vol. 62, No. 24, r 1/6/43, p. 386.)

$5731 \log 6$ G.B. ..

Heat Treatment of the Wrought Aluminium Alloys. Pt. II-Equipment. (W.L.A.D.A. Information Bulletin, No. 4.)

57411250 U.S.A. ... Quench on Rising or Falling Heat? (Metal Progress, Vol. 43, No. 5, May, I943, pp. 715 and 752.)

$5751125^{2}$ U.S.A. $\quad$.. Heating of Heavy Forging Billets. (Metal Progress, Vol. 43, No. 5, May, 1943, pp. 724-725.)

57611276 G.B ... $\quad$... The Heat Treatment of Wrought Aluminium Alloys (Issued by the Wrought Light Alloys Development Association). (Engineering, Vol. 155, No. $4,041,25 / 6 / 43$, p. 505.) 
ITEM

No.

$578 \quad 10687$ G.B. ...

57910729 U.S.A.

$580 \quad 1073^{\circ}$ U.S.A.

$581 \quad 10824$ G.B. .

582 II4I6 G.B. ...

$5^{8} 3$ 10702 G.B. ...

$584 \quad 10784 \quad$ U.S.A.

585 10907 G.B. ...

586 I0982 G.B. ...

$5^{87}$ III55 G.B. . .

$588 \quad 10765$ G.B. . .

$589 \quad 10767$ G.B.

590 I0770 G.B. ...

591 IO77I G.B. ...

$592 \quad$ I 1005 U.S.A.

593 10652 G.B. ...

594 II419 G.B. ...
TITLE AND JOURNAL.

\section{Corrosion.}

Sterilization of Cooling Water. (Plastics, Vol. 7, No. 72, May, 1943, pp. 219-220.)

New Methods for Examination of Corroded Metal. (F. H. Champion, Metallurgia, April, 1943, pp. 217-220.) (Met. Vick. Tech. News Bull., No. $864,3 \% / 4 / 43$, p. 9.)

Protecting Buried Metals Against Corrosion. (S. Thayer, Trans. A.S.M.E., Vol. 64. No. 8, Nov., 1942, pp. 805-808.)

Application of Cathodic Protection for Corrosion Protection (Submerged Structure). (R. J. Sullivan, Trans. A.S.M.E., Vol. 64, No. 8, Nov., I942, pp. 809-8I 5.)

Marine Corrosion. (Engineering, Vol. I 55, No. 4,O31, 28/5/43, pp. 435-436.)

Corrosion of Lead. (Metal Industry, Vol. 62, No. $25,18 / 6 / 42$, p. 390.)

\section{Powder Metallurgy.}

Powder Metallurgy. (W. D. Jones, Trans. of the North-East Coast Inst. of Engrs. and Shipbuilders, March, 1943, pp. I39-146.) (Met. Vick. Tech. News Bull., No. 859, 26/3/43, p. 8.)

New Powder Metal Press. (Metal Progress, Vol. 43, No. 3, March, 1943, p. 444.)

Powder Metallurgy-Pt. I. (Eng. Digest, Vol. 4, No. 1, Jan., 1943, p. 31.)

Developments in Powder Metallurgy. (J. Wulf, Metal Industry, Vol. 62, No. 23, 4/6/43, p. 362.)

A New Injection Moulding Powder "Lustrac." (British Plastics, Vol. 15, No. I69, June, 1943, p. 49.)

\section{Tools.}

Conservation of Tools by the Macrome Treatment. (Autom. Eng., Vol. 33, No. 435, April, 1943, p. I69.)

Negative Rake on Milling Cutters. (Machinery, Vol. 62, No. $1,595,6 / 5 / 43$, p. 486 .)

Firth Brown Mitia Carbide Tools. (Machinery, Vol. 62 , No. 1,595, 6/5/43, pp. 497-498.)

Carbide Inserted Tooth Milling Cutters Having Negative Rakes. (Machinery, Vol. 62, No. 1,595, 6/5/43, pp. 5oI-5o2.)

New Surface Hardening Tools. (Autom. Ind., Vol. 88 , No. $6,15 / 3 / 43$, p. 200.)

\section{Bonding.}

The Redux Process for Bonding. (Aeroplane, Vol. 64 , No. 1,669, $21 / 5 / 43$, p. 602.)

Bonding of Light Alloys. (Metal Industry, Vol. 62, No. $25,18 / 6 / 43$, p. 394.) 
ITEM R.T.P.

NO. REF.

TITLE AND JOURNAL.

\section{Moulding.}

59511535 G.B. ... ... Uniform Casting for Injection Moulders. (H. Senior, British Plastics, Vol. I5, No. I7o, July, I943, pp. 82-84.)

596 II595 Germany ... Device for Regulating Moulding Temperature for Plastics (from Kunststoffe, Vol. 32, 1942, p. 947). (Brandenburger, Plastics, Vol. 7, No. 74, July, I 943 , p. 294.)

597 I1600 G.B. ... ... The Manufacture of Precision Mouldings. (W. M. Halliday, Plastics, Vol. 7, No. 74, July, I943, pp. 308-3ㅈ.)

598 I1610 U.S.A. ... Heatronic Moulding of Plastics. (Ind. and Eng. Chem. (News Ed.), Vol. 2I, No. Io, 25/5/43, p. 763.$)$

599 I1633 U.S.A. ... Original Methods and Tools for Bending and Welding of Steel Tubing. (Aviation, Vol. 42, No. 5, May, 1943, pp. 236-237 and 394.)

$600 \quad$ II702 U.S.A.

The Modern Method of Making Curved Plywood by Omnidirectional Pressure (Flexible Pressure Bag Moulding). (T. D. Perry, A.S.M.E. Preprint, April 26-28, 1943.)

\section{c. Inspection.}

\section{X-Ray and Similar Methods of Analysis.}

601 10613 G.B. ... ... Crack Detection by the Hyglo Process. (Aircraft Production, Vol. 5, No. 6, June, 1943, p. 297.)

60210675 G.B. ... ... X-Ray Testing of Welds. (C. B. Clason, Welding Engineer, Aug., 194.2, pp. 27-3I.) (Met. Vick. Tech. News Bull., No. $837,23 / 10 / 42$, p. 6.)

603210685 G.B. ... ... Crystallography for Routine Analysis. (C. H. Walker, M.V. Gaz., April, 1943, pp. 167-173.) (Met. Vick. Tech. News Bull., No. 864, 3o/4/43, p. 7.)

604 ro686 G.B. ... ... Annealed. Aluminium as Revealed by X-Rays. (E. E. Spillet, J. Inst. Mat., April, 1943, pp. 149-175.) (Met. Vick. Tech. News Bull., No. $864,3 \% / 4 / 43$, p. 8.$)$

60510709 G.B. ... ... Detecting Surface Flaws in Non-Magnetic Materials . (G. Ellis, Iron Age, 17/12/42, pp. 56-59.) (Met. Vick. Tech. News Bull., No. $854,19 / 2 / 43$, p. 9.)

60610790 G.B. ... ... Inspection by Fluorescence (Hyglo Process). (Aeroplane, Vol. 64, No. I,666, 30/4/43, p. 495.)

60710826 G.B. ... ... Application of the Spectrograph to Steel Work Analysis. (H. T. Shirley and E. Elliott, Engineering, Vol. 155, No. 4,031, 28/5/43, pp. 437-440.)

608 10903 Germany ... Microscopic Method of Measuring Surface Roughness (from Die Werkzeugmaschine, Vol. 6, No. 9, May, 1942, pp. 267-268). (Eng. Digest, Vol. 4, No. I, Jan., 1943, p. 20-2 I.)

60910978 G.B. ... ... Electrographic Methols of Surface Analysis. (M. S. Hunter and others, Metal Industry, Vol. 62, No. $23,4 / 6 / 43$.) 
 (Contd.). (M. S. Hunter and others, Metal Industry, Vol. 62, No. 24, I I/6/43, pp. 373-374.)
613 II083 G.B. ... ... Applications of the Spectrograph to Steelwork Analysis. (Engineering, Vol. 155, No. 4,038, $4 / 6 / 43$, pp. $45^{6-457 .)}$

\section{Mechanical Testing (General Methods).}

614 I0699 G.B. ... ... Rapid Non-Destructive Material Testing. (W. A. Knoop, Instruments, Jan., 1943, pp. I4-15.) (Met. Vick. Tech. News Bull., No. 859, 26/3/43, p. 7.)

6r 5 ro783 U.S.A. ... Hardness Testing of High Speed Steel at High Temperatures. (E. C. Bishop and M. Cohen, Metal Progress, Vol. 43, No. 3, March, I943, pp. 41 3-416, 442.)

61610959 G.B. ... ... Accelerated Testing of Plastics for Weathering Resistance. (L. K. Merrill and C. S. Myers, Engineering Inspection, Vol. 7, No. 2, AprilJune, p. 9-14.)

6I7 10966 G.B. ... ... Mercury Cracking Tests-Procedure and Control (Detecting Excessive Stresses in Copper Base Alloys). (H. Rosenthal and A. L. Jamieson, Engineering Inspection, Vol. 7, No. 3, Autumn, 1942, pp. 9-13.)

618 IIOI7 U.S.A. ... Rapid Identification Tests for Manganese and Sulphur in Steel. (Metal Progress, Vol. 43, No. 4, April, 1943, p. 572.)

619 III70 U.S.A. ... Rohm and Haas Laboratory Equipment for Testing Transparent Plastics (Photographs). (Ind. and Eng. Chem. (News Ed.), Vol. 22, No. 9, 10/5/43, pp. 690-69I.)

620 II235 G.B. ... ... Significance of Mechanical Test Properties of Metals (Contd.). (H. O'Niell, Engineering, Vol. I56, No. 4,042, 2/7/43, pp. 18-20.)

621 I 1258 U.S.A. ... Spot Test for Manganese in Steel. (Metal Progress, Vol. 43, No. 5, May, 1943, p. 746.)

622 II266 G.B. ...

Tensile and Other Mechanical Test Properties of Metals. (Abstract of Paper Presented to Inst. of Mech. Engs) (H. O'Neill, Engineer, Vol. I75, No. $4,563,25 / 6 / 43$, pp. 503-504.)

\section{INSTRUMENTS.}

\section{Aircraft.}

62310724 U.S.A. ... Optimum Settings for Automatic Controllers. (J. G. Ziegler and N. B. Nichols, Trans. A.S.M.E., Vol. 64, No. 8, Nov., r942, pp. 759-768.)

624 10852 U.S.A. ... Graphical Analysis of Delay of Response in Air Speed Indicators. (K. J. De Juhasz, J. Aeron. Sci., Vol. 10, No. 3, March, 1943, pp. 91-97.) 
TITLES AND REFERENCES OF ARTICLES AND PAPERS.

$\begin{array}{rrr}\text { ITEM } & \text { R.T.P. } \\ \text { No. } & \text { REF. } \\ 625 & \text { Ir3II } & \text { Germany } \\ & & \\ 626 & \text { I } 1374 & \text { G.B. ... } \\ 627 & \text { II576 } & \text { U.S.A. }\end{array}$

628 I0703 G.B. ...

629 I0706 G.B. ...

$630 \quad 10812$ G.B. ...

$631 \quad 10833$ U.S.A.

632 Iogo2 Germany

633 II433 Germany ... Accelerometer for Determining Shock Load on Vehicle. (P. Langer, Symposium of Papers on the Elements of Machine Design (Aachen), pp. 49-5o.)

634 I 125 I U.S.A. … New Pathways in Engineering (New Strain Gauges and Methods of Stress Analysis). (A. V. de Forest, Metal Progress, Vol. 43, No. 5, May, 1943, pp. 719-723 and 750.)

635 I1272 U.S.A. ... Sheet and Wire Gauge Reform-the "Preferred Number" System of the American Standards Association. (Engineer, Vol. I75, No. 4,563 , 25/6/43, pp. 504-507 and 5II.)

$63_{3} \quad 11282$ G.B. ... $\quad$... Recording Dilatometer for Metal Specimens. (L. R. Stanton, Engineering, Vol. I 55, No. 4,041, 25/6/43, pp. 518-519.)

Electrical, Spectrometers, etc.

637 10672 G.B. ... ... The Londex Welder Timer. (Electrician, 16/10/42, p. 4I9.) (Met. Vick. Tech. News Bull., No. 837, $23 / 10 / 42$, p. 3.)

$63^{8}$ 10813 G.B. ... ... The Electrical Screening of Sparking Apparatus for Use in Spectrographic Analysis. (D. M. Smith and $A$. Walsh, Journal of Scientific. Instruments, Vol. 20, No. 4, April, 1943, pp. 63-64.)

63911053 U.S.A. ... The Betatron-New Powerful X-Ray Machine. (A. R. Wildhagen, Sci. Am., Vol. I68, No. 5, May, 1943, pp. 207-209.) 


$\begin{array}{ccc}\text { ITEM } & \text { R.T.P. } \\ \text { NO. } & \text { REF. } \\ 640 & \text { III57 } & \text { U.S.A. } \\ & & \\ 641 & \text { II563 } & \text { U.S.A. } \\ 642 & \text { II577 } & \text { U.S.A. }\end{array}$

64311042 G.B. ...

644 III59 U.S.A.

645 Iт239 U.S.A.

646 II240 U.S.A.
TITLE AND JOURNAL.

An Improved Current Integrator. (J. Morris Blair, Rev. of Sci. Insts., Vol. I 4, No. 3, March, 1943, pp. 64-67.)

Photo-Electric Glossmeter. (Rev. of Sci. Instrum., Vol. 14, No. 4, April, 1943, p. I 19.)

An Experimental Mass Spectrometer. (N. D. Coggeshal and E. B. Jordan, Rev. of Sci. Instrum., Vol. 14, No. 5, May, 1943, pp. I25-1 29.)

\section{Flow Meters.}

An Instrument to Measure Minute Changes in Specific Inductive Capacity of Cardboard and Hence to Determine its Water Content. (S. D. Gardiner, J. Soc. Chem. and Ind., Vol. 62, No. 5, May, 1943, pp. 75-76.)

Erratum: An Accurate High Sensitivity Apiezon Oil McLeod Gauge. (J. Bannon, Rev. of Sci. Insts., Vol. 14, No. 3, March, 1943, p. 77.)

An Improved Meter for the Measurement of Gas Flow Rates. (W. G. Appleby and W. H. Avery, Ind. and Eng. Chem. (Anal. Ed.), Vol. 15, No. 5 , I 8/5/43, pp. 349-350.)

Current Methods of Measuring Foam. (S. Ross, Ind. and Eng. Chem. (Anal. Ed.), Vol. 15, No. 5, I $8 / 5 / 43$, pp. 329-334.)

\section{Miscellaneous (including Optical).}

$647 \quad{ }^{10785}$ U.S.A. $\quad \ldots$ Metal. Washing Machine. (Metal Progress, Vol. 648 I0813 G.B. ... 43, No. 3, March, 1943, p. 444.)

A Bath for Use in the Graduation and Testing of Thermometers. (A. Grace and J. A. Hall, Journal of Scientific Instruments, Vol. 20, No. 4, April, r943, pp. 6o-63.)

649 I0863 U.S.A. $\quad$.. Split Second Timing by Special Tuning Forks. (Sci. Am., Vol. 168, No. 4, April, 1943, p. i72.)

$65^{\circ} \quad$ 1087o U.S.A.

$65^{1} \quad 10900$ G.B. ...

A New Low Cost Air Clamp. (Sci. Amer., Vol. I68, No. 4, April, 1943, p. I84.)

Miniature. Instruments. (J. M. Whittenton, Eng. Digest, Vol. 4, No. I, Jan., I943, pp. I I-I 2.)

$65^{2}$ rogor G.B. ...

653 I 106I U.S.A.

654 I294 G.B.

Inkless Recording. (P. E. Twiss, Eng. Digest, Vol. 4, No. I, Jan., I943, pp. I 2-16.)

Armour Plate Width Measured from a Distance by Mirrors. (Sci. Am., Vol. 168, No. 5, May, 1943, p. 224.)

Calibrating a Microscope. (Metal Industry, Vol. 62 , No. $26,25 / 6 / 43$, p. 403 .)

\section{PRODUCTION.}

\section{Control and Organisation.}

655 ro635 Germany ... German Production Methods. (Flight, Vol. 43,

656 ro766 G.B. ... ... The Willow Run Bomber Plant Production Method, etc. (Machinery, Vol. 62, No. I,595, 6/5/43, pp. 477-484.) 


\begin{tabular}{|c|c|c|}
\hline $\begin{array}{c}\text { ITEM } \\
\text { No. }\end{array}$ & & $\begin{array}{l}\text { T.P. } \\
\text { REF. }\end{array}$ \\
\hline 657 & 10787 & G.B. \\
\hline 658 & $1096 I$ & G.B. \\
\hline 59 & 10962 & $\mathrm{G}$ \\
\hline
\end{tabular}

$660 \quad 10963$ G.B. ..

66110989 U.S.A

66210996 U.S.A.

663 I1236 G.B. ...

664 I I 281 G.B. ...

665 I I 303 G.B.

666 I1310 Germany

66711406 U.S.A.

668 I1 $44 \mathrm{I}$ U.S.A.

66911479 G.B. ...

$670 \quad 10653$ U.S.A.

67 I I0956 Italy ...

$672 \quad 10972$ G.B. ...

$673 \quad 10974$ China

674 1 1046 G.B. ...

$675 \quad 11084$ U.S.A.
TITLE AND JOURNAL.

Production Publicity. (Aeroplane, Vol. 64, No. ' $, 666,3 \% / 4 / 43$, p. 494.)

Quality, Production and Progress. (A. N. Appleby, Engineering Inspection, Vol. 7, No. 2, AprilJune, 1942, pp. 22-24.)

The Statistical Control of Quality in Production Engineering. (R. Royan and H. Rissik, Engineering Inspection, Vol. 7, No. I, Jan.-March, I942, pp. 4-I9.)

Standards for Precision Engineering. (G. $O$. Watson, Engineering Inspection, Vol. 7, No. I, Jan.-March, 1942, pp. 20-24.)

Statistical Data on American War Production. (Autom. Ind., Vol. 88,- No. 6, I 5/3/43, pp. 53-97.) Alphabetical List of Government Agencies. (Autom. Ind., Vol. 88, No. 6, 15/3/43, pp. I 24-I 25.)

New Kodak School of Industrial Radiography. (Elect. Eng., Vol. 15, No. 185, July, 1942, pp. 58-59.)

Wage Systems and Incentives. (T. E. A. K. Jackson, Engineering, Vol. I55, No. 4,04I, $25 / 6 / 4^{2}$, pp. $5^{16-517 .)}$

Maximum Works Production. (Engineer, Vol. I 76 , No. $4,564,2 / 7 / 43$, pp. 1 $3^{-1} 4$.)

Changes in the German Patent Laws. (Flugsport, Vol. 35 , No. 10, 16/6/43, pp. I 3 I-1 32.)

New Magnesium Production Plant. (F. J. van Antwerpen, Ind. and Eng. Chem., Vol. 212, No. $8,25 / 4 / 43$, pp. 545-547.)

Modification Centres for Effecting Changes in Aircraft Design as Dictated by Battle Front Experience (for Consolidated Aircraft). (S. Hotchkiss, Aviation, Vol. 42, No. 4, April, 1943, pp. 1 34-1 36 and 329-333.)

Control of Short Brothers by the Government. (Inter. Avia., No. $867,1 / 5 / 43$, pp. I9-20.)

\section{Research and Training.}

T. P. Wright's Address to the Institute of Aeronautical Sciences. (Flight, Vol. 43, No. I,794, I $3 / 5 / 43$, p. 499 .)

Jalian National Research Council. (Inter. Avia., No. 861, I $7 / 3 / 43$, p. I 4.)

Research in South Africa (Rubber, Road Research, etc.). (Engineer, Vol. I75, No. 4,560, 4/6/43, p. 447.)

Engineering Developments in China. (Engineer, Vol. 175, No. 4,560, 4/6/43, pp. 449-45I.)

Education and Training for Engineers (Contd.). (Engineering, Vol. I 55, No. 4,039, I I $/ 6 / 43$, pp. 476-477.)

Organisation of American Scientists for the War. (K. T. Compton, Nature, Vol. I5I, No. 3,839, 29/5/43, pp. 6oI-606.) 
ITEM R.T.P.

NO. REF.

TITLE AND JOURNAL.

676 II2I5 U.S.S.R.

Biogeochemical Research in the U.S.S.R. (A. P. Vinodradov, Nature, Vol. I5I, No. 3,841, I 2/6/43, pp. 659-66r.)

677 II 270 G.B. .

Science and the State. (Engineer, Vol. 175, No. $4,5^{6} 3,25 / 6 / 43$, p. 507.)

$678 \quad$ II275 G.B. ...

Education and Training for Engineers-II. (Report of the Inst. Elect. Engs.) (Engineering, Vol. I55, No. 4,04I, 25/6/43, pp. 504-505.)

$\begin{array}{lll}679 & 11298 & \text { G.B. . . } \\ 680 & \text { I } 305 & \text { G.B. . . } \\ 681 & \text { I } 1496 & \text { U.S.S.R }\end{array}$

Engineers and the British Empire-I. (M. Smith, Engineer, Vol. I76, No. 4,564, 2/7/43, pp. 2-3.)

National Research. (Sir Stafford Cripps, Engineer, Vol. 176 , No. $4,564,2 / 7 / 43$, p. 17.)

Russian Research and Development Awards. (Inter. Avia., No. 868, Io/5/43, pp. 15-16.)

\section{Aircraft Production Methods.}

682 10608 G.B. ...

Small Scale Track Assembly. (Aircraft Production, Vol. 5, No. 56, June, 1943, pp. 259-26r.)

683 I0609 G.B. ...

684 Io6ro G.B. ...

Production of the De Havilland Mosquito. (W. E. Goff, Aircraft Production, Vol. 5, No. 56, June, 1943, pp. 262-273.)

Metal Aircraft Units Produced with Woodworking Machinery. (Aircraft Production, Vol. 5, No. 56, June, 1943, pp. 277-279.)

685 I0612 G.B. ..

Producing Bomber Castings-Pt. I. (Aircraft Production, Vol. 5, No. 56, June, 1943, pp. 292-296.)

68610845 U.S.A.

687 II316 Germany

The Manufacturing Processes of Plastic Planes. (Pegasus, Vol. I, No. 2, Feb., 1943, pp. 1-3 and 16.)

Method of Joining Plastic Aircraft Parts by Means of Heat and a Special Cement. (Pat. series No. 5, 732,922.) (Nobel, Flugsport, Vol. 35, No. Io, 16/6/43, pp. 29-30.)

688 II350 Germany ... Conveyor System for the Mass Production of Bulky Aircraft Parts. (Pat. series No. 4, 732,868.) (Henschel, Flugsport, Vol. 35, No. 9, 19/5/43, p. 25.)

689 II388 U.S.A. ... Wheel Maintenance at American Airlines. (R. Miller, Aviation, Vol. 42, No. 3, March, 1943, pp. $245^{-247}$ and 380 .)

Methods (General).

69010683 G.B. ... ... Adapting Automatic Electric Welding to Routine Production. (J. M. Keir, Weld. J., March, 1943, $p p$. 173-I79.) (Met. Vick. Tech. News Bull., No. $864,30 / 4 / 43$, p. 3.)

69 I 10698 G.B. ... ... Flash Welding-I. (L. A. Ferney, Welding, March, 1943, pp. 154-160.) (Met. Vick. Tech. News Bull., No. $859,26 / 3 / 43$, p. 4.$)$

692 ro7oo G.B. ... ... Making Alloy Steel by Arc Welding. (J. A. Newman, Steel, II/I/43, pp. 74-76, 78 and 80.) (Met. Vick. Tech. News Bull., No. $859,26 / 3 / 43$, p. 7.) 
ITEM

No.

69310704 G.B. ...

$\begin{array}{lll}694 & 10705 & \text { G.B. ... } \\ 695 & 10775 & \text { U.S.A. } \\ & & \\ 696 & 10832 & \text { U.S.A. } \\ 697 & 10867 & \text { U.S.A. }\end{array}$

69810975 G.B. ...

$699 \log 8$ I $\quad$ G.B. .

$700 \quad 11010$ U.S.A.

701 11032 Germany

$702 \quad 11035$ G.B. ...

703 II 27 I G.B.

704 II274 G.B. .

705 II3I3 Germany

$706 \quad 11317$ Germany

707 11336 Germany

$708 \quad 1095^{8} \quad$ G.B. . .

$709 \quad 10967$ G.B. ...
TITLE AND JOURNAL.

Resistance, Welds with Electronic Control. (T. R. Lawson, Westinghouse Engineer, Nov., 1942, pp. Io9-1 I3.) (Met. Vick. Tech. News Bull., No. $854,19 / 2 / 43$, p. 4.)

Electrolytic Tin-Plating Lines and Reflowing Methods. (J.R. Erbe, Westinghouse Engineer, Nov., 1942, pp. I29-130.) (Met. Vick. Tech. News Bull., No. $854,19 / 2 / 43$, p. 5.)

Network of Shops for Heat Treating Small Armour. (L. Strouffer, Metal Progress, Vol. 43, No. 3, March, 1943, pp. 390-39r.)

Rapid Metal Plating in Situ (without Dismantling). (Sci. Am., Vol. I68, No. 2, Feb., I943, p. 86.)

Templates Rapidly Produced with New Transfer Film (Pliofilm). (Sci. Am., Vol. 168, No. 4, April, 1943, pp. I77-178.)

Recent Advance in the Electro-Metallurgical Industry. (Engineer, Vol. 175, No. 4,560, 4/6/43, p. 451.)

Tube Forming by the Spun End Process. (Metal Industry, Vol. 62 , No. $23,4 / 6 / 43$, p. $35^{8}$.)

Ships Welded on a Production Line. (G. F. Wolfe, Metal Progress, Vol. 43, No. 4, April, 1943, pp. 550-554.)

Production Methods for Magnets (Metal Powders Bonded with Synthetic Resin) (from the German). (Plastics, Vol. 7, No. 73, June, 1943, p. 259.)

Co-operation Between User and Moulder in the Production of Precision Mouldings. (W. M. Halliday, Plastics, Vol. 7, No. 73, June, 1943, pp. 262-267.)

Marking Methods and War Production. (Engineer, Vol. 175, No. 4,563, 25/6/43, pp. 51 2-514.)

Statistical Methods in Industry. (Published by Iron and Steel Industrial Research Council, Brit. Iron and Steel Fed.) (Engineering, Vol. I 55, No. 4,04I, 25/6/43, p. 503.)

Device for the Cold Bending of Alloy Tubes up to $20 \mathrm{~mm}$. Diamster (no Filling Requiredi. (Junkers, Flugsport, Vol. 35 , No. 10, I6/6/43, p. I 30.)

Method of Preparing Hollow Plastic Sections by Means of an Internal Flexible. Air Bag. (Pat. series No. 5, 732,923.) (Focke-Wulf, Flugsport, Vol. 35 , No. 10, 16/6/43, p. 30.)

Mobile Unit for Periodic Cleaning of the Lubricating System of Machine Tools. (Flugsport, Vol. 35, No. 9, 19/5/43, pp. I I I-I I 2.)

\section{Inspection, Routine Analysis.}

... X-Ray Technique in the Industrial Laboratory. (H. P. Rooksby, Engineering Inspection, Vol. 7, No. 2, April-June, r942, pp. 4-8.)

Lighting for Inspection. (R. O. Ackerley, Engineering Inspection, Vol. 7, No. 3, Autumn, 1942, pp. 16-22.) 


\begin{tabular}{|c|c|c|}
\hline $\begin{array}{c}\text { ITEM } \\
\text { No. }\end{array}$ & \multicolumn{2}{|c|}{$\begin{array}{l}\text { R.T.P. } \\
\text { REF. }\end{array}$} \\
\hline 710 & 11165 & G.B. $\ldots$ \\
\hline 711 & I I I 78 & G.B. ... \\
\hline 712 & 10905 & Germany \\
\hline 713 & I 1079 & Germany \\
\hline 7.14 & 11184 & U.S.A. \\
\hline 715 & I.1OI 3 & U.S.A. \\
\hline 716 & 10857 & U.S.A. \\
\hline 717 & 11003 & U.S.A. \\
\hline 718 & I1054 & U.S.A. \\
\hline 719 & 11057 & U.S.A. \\
\hline 720 & I I 2 I 2 & G.B. $\ldots$ \\
\hline 721 & I I 233 & G.B. $\ldots$ \\
\hline 72 & I I 235 & G.B. \\
\hline
\end{tabular}

TITLE AND JOURNAL.

Inspecting Apparatus for Small Parts. (Engineering, Vol. 155, No. 4,040, 18/6/43, pp. 487 and 490.)

Crystallography for Routine Analysis. (C. $\mathrm{H}$. Walker, Engineer, Vol. 175 , No. 4,562 , $18 / 6 / 43$, pp. 492-494.)

\section{Equipment, Lay-Out.}

The Most Efficient Layout of Electric Arc Furnace Steel Works. (From Stahl und Eisen, Vol. 6r, No. 29, July, 1941, $p p$. 685-694.) (H. Müller, Eng. Digest, Vol. 4, No. I, Jan., 1943, pp. 27-30.)

Economising Electrical Energy in German Industry. (Engineering, Vol. I 55, No. 4,038, 4/6/43, p. $45^{\circ}$.)

New Production Equipment. (Autom. Ind., Vol. 88 , No. $7,1 / 4 / 43$, pp. $3^{8}$ and $60-68$.)

\section{Scrap Salvage.}

Practical Programmes for Reclamation of Metal Scrap (Symposium of Articles). (J. L. Cannon and others, Metal Progress, Vol. 43, No. 4, April, 1943, pp. 561-569.)

\section{Welfare of Workers.}

Anti-Sabotage Lighting. (J. A. Summers, Sci. Am., Vol. 168, No. 4, April, 1943.)

Accident Prevention in Aircraft Manufacture. (W. S. Rhodes, Autom. Ind., Vol. 88, No. 6, I5/3/43, pp. 151-1 54 and 352-354.)

Industrial Safety (Research and Development). (Sci. Am., Vol. 168, No. 5, May, 1943, pp. 2 I6-2I8.)

Feed Control Improves Safety in Magnesium Plant. (Sci. Am., Vol. 168, No. 5, May, 1943, p. 222.)

Hours of Work, Health and Efficiency. (Nature, Vol. I5 1 , No. $3,841,12 / 6 / 43$, pp. $65^{I-6} 5^{2}$.)

Lighting as a Factor in Production. (Engineering, Vol. 156 , No. $4,04^{2}, 2 / 7 / 43$, p. 12.)

Safety with X-Rays. (H. G. Long, Elect. Eng., Gt. Brit., Vol. 15, No. 185, July, 1942, pp. 52-54 and 84.)

\section{TRANSPORT.}

Tanks, Jeeps, etc.

72310757 G.B. ... … The G.P. War Truck (Jeep). (Autom. Eng., Vol.

$724 \quad 1077^{2}$ U.S.A.

33, No. 435, April, 1943, pp. ' ${ }^{1}{ }^{\mathrm{I}-1} 3^{6}$.)
Some Notes on Armour Plate for Ships and Tanks. (Metal Progress, Vol. 43, No. 3, March, 1943, pp. $382-387 \cdot)$

72510773 U.S.A.

Tank Armour. (G. M. Barnes, Metal Progress, Vol. 43, No. 3, March, I943, p. 389.)

$726 \quad 10774$ U.S.A.

Tank Design. (Metal Progress, Vol. 43, No. 3, March, 1943, pp. $3^{89}, 43^{2}, 43^{6 .)}$ 
ITEM R.T.P.

No. REF.

$727 \quad 10776$ U.S.A.

TITLE AND JOURNAL.

Welded Hull for Combat Tank. (E. Brookes, Metal Progress, Vol. 43, No. 3, March, 1943, pp. 392, 395, 430.)

$728 \quad 10856$ U.S.A.

Army Motor Vehicles for Various Purposes (Instruction Maintenance, etc.). (Sci. Am., Vol. I68, No. 4, April, 1943, p. 153.)

729100866 U.S.A.

New Flame Detector for Use in Tanks. (Sci. Am., Vol. 168, No. 4, April, 1943, p. 174.)

$73^{\circ} \quad 11000$ U.S.A.

$731 \quad 11175$ G.B. ... Vol. 88 , No. $6,15 / 3 / 43$, p. 138 .)

Welded Armoured Fighting Vehicles. (Engineer, Vol. I75, No. 4,562, I8/6/43, pp. 485-486.)

$73^{2}$ I I186 Germany

German Mark IV Tank. (Autom. Ind., Vol. 88, No. $7,1 / 4 / 43$, p. 39.) .

733 10762 G.B. ...

Battery Electric Vehicle. (Autom. Eng., Vol. 33, No. 435, April, 1943, pp. 155-159.)

$734 \quad 11192$ Germany

Oil Waggons for Carrying Oil Supply for Machine Tools. (Junkers, Flugsport, Vol. 35, No. 8, 21 $/ 4 / 43$, p. 95.)

$735 \quad 11284$ G.B. . .

Counter Pressure Brake Testing of Locomotives.

(E. Cattanes, Engineering, Vol. I 55, No. 4, O4I, 25/6/43, p. 514.)

\section{WIRELESS AND ELECTRICITY.}

\section{Radio and Television.}

$736 \quad 10987$ G.B. ...

Wireless Engineer, Abstracts and References. (June, 1943.)

737 I 1068 U.S.A.

Radio Progress during 1942. (Procs., I.R.E., Vol. 31, No. 4, April, I943, pp. I 27-I3I.)

$738 \quad 11069$ U.S.A.

Frequency Modulation Distortion in Loud Speakers. (G. L. Beers and H. Belar, Procs., I.R.E., Vol. $3^{1}$, No. 4, April, 1943, pp. 1 32-1 $3^{8}$.)

739 11071 U.S.A

Radio Frequency Operated High Voltage Supplies for Cathode Ray Tubes. (O. H. Schade, Procs., I.R.E., Vol. 31, No. 4, April, 1943, pp. I58-163.)

$740 \quad$ III II U.S.A.

Condenser Scoop Design. (E. F. Hewins and J. R. Reilly, Soc. of Naval Architects and Marine Engs. (Transactions), Vol. 48, 1940, pp. 277-304.)

74 III74 U.S.A.

Optimum Current Distribution on Vertical Antennas. (L. La Paz and G. A. Miller, Procs. Inst. Rad. Engs., Vol. 31, No. 5, May, 1943, pp. 214-232.)

742 I1210 Germany ... Installation of Radio Altimeters in the Wing Structure. (Pat series No. 3, 731,987.) (Siemens, Flugsport, Vol. 35, No. 8, 21 $/ 4 / 43$, p. 20.)

743 I1214 G.B. ... ... Radio Receiver Design (Book Review). (Nature, Vol. I 5 I, No. 3,84I, I 2/6/43, p. 657.)

$744 \quad 11237$ G.B. . .

Factors Determining the Choice of Carrier Frequency for an Improved Television System. (B. J. Edwards, Engineering, Vol. I5, No. 185 , July, 1942, pp. 60-64.)

74511238 G.B. ... ... Measuring Instruments for Radio. (E. H. W. Banner, Elect. Eng., Vol. I5, No. $18_{5}$, July, 1942, pp. 76-79.) 
ITEM R.T.P.
NO. REF.

$746 \quad 10673$ G.B. .

747 I0818 G.B. ...

$748 \quad$ Iog 84 G.B. ...

749 I1072 U.S.A.

$75^{\circ} \quad$ I 1087 G.B. ...

75I III73 Germany

$75^{2}$ II218 G.B. .

753 I I 280 G. B. . .

754 I I312 Germany

$755 \quad$ I I 578 U.S.A.

$75^{6} 10825$ G.B. ..

757 I 1073 U.S.A.

758 11075 G.B. .

759 I I213 G.B. ...

$760 \quad 10817$ G.B. ...

$7^{61}$ I0862 U.S.A.

$7^{62}$ I $1221 \quad$ G.B. ...
TITLE AND JOURNAL.

Electricity (General).

The Electrical Equipment of the New Deep Shelters. (Electrical Review, $16 / 10 / 42, p p$. 481-484.) (Met. Vick. Tech. News Bull., No. $8_{37}, 23 / 10 / 42$, p. 4.)

An Automatic Low Frequency Analyser (Electrobiology). (W. G. Walter, Elect. Eng., Vol. I5, No. I 84, June, I942, pp. 9-13.)

Discussion on the Electric Spark in Air. (J. Inst. Elect. Engs., Vol. 9o, No. 29, Pt. I, May, I943, pp. 197-199 and 200-202.)

Network Theory, Filters and Equalizers (Pt. I). (F. E. Terman, Procs., I.R.E., Vol. 31, No. 4, April, I943, pp. I64-175.)

A New Electrical Frequency Divider. (Nature, Vol. I5 I, No. $3,839,29 / 5 / 43$, pp. 62 I-622.)

Improvement of the Insulating Properties of $P . V$. Chlorides with the Addition of Silicates. (I.G. Farben, Frankfurt/Main, D.R.P. 704,301, 28/3/4r. Zeit. für Fernmeldetechnik, Vol. 23, Heft $1,16 / 1 / 42$, p. 1 2.)

The High Pressure Gas-Filled Cable. (Nature, Vol. I 5 I, No. 3,84I, I 2/6/43, p. 669.)

High Rupturing Capacity Air-Break-Circuit Breakers. (Engineering, Vol. I 55, No. 4,041, 25/6/43, p. $5^{\text {I3.) }}$

Wire Rope Connections (Electrical Cutting Gives Pointed Ends which are Secured by Passing Through a Tube and Twisting). (Messerschmitt, Flugsport, Vol. 35, No. 10, 16/6/43, p. 1 29.)

An Electrical Transducer (Vibration Recorder) Circuit for Use with Capacity Pick-up Devices.

(E. V. Potter, Rev. of Sci. Instrum., Vol. I4, No. .5, May, r943, pp. I 30-135.)

\section{Electronics.}

Electron Diffraction. (G. P. Thompson, Engineering, Vol. I55, No. 4,o31, $28 / 5 / 43$, p. 436.)

Electron Method for Soldering Crystal Units in Radio Equipment. (Procs., I.R.E., Vol. $3^{\text {I, No. }}$ 4, April, rg43, p. 40.)

Electron Diffraction (Contd.). (G. P. Thompson, Vol. I 55, No. 4,038, 4/6/43, pp. 444-445.)

High Frequency Thermionic Tubes (Book Review). (Nature, Vol. I 51, No. 3,841, I 2/6/43, p. 655.) Magnetism, etc.

Reflexion of Electromagnetic Waves from a Parabolic Ionised Layer. (O. E. H. Rydbeck, Phil. Mag., Vol. 34, No. 232, May, I943, pp. 342-348.) Variations in the Earth's Magnetic Field Through the Geologic Ages. (A. G. McNish, Sci. Am., Vol. 168, No. 4, April, 1943, pp. I66-167.)

Recent Advances in the Theory of the Fundamental Particles of Physics. (H. J. Bhabha, Nature, Vol. I 5 I, No. 3,840, 5/6/43, pp. 628-629.) 
TITLES AND REFERENCES OF ARTICLES AND PAPERS.

ITEM

No.

RE. $\begin{array}{rrr}763 & 10718 & \text { U.S.A. }\end{array}$

$764 \quad 10723$ U.S.A.

$765 \quad 10726 \quad$ U.S.A.

$766 \quad 10727$ U.S.A.

$767 \quad 10983$ G.B. . .

76811086 G.B. ...

$769 \quad$ III76 G.B. . . .

770 II219 G.B. ...

771 I1222 G.B. ...

77211223 G.B. ..

77311227 G.B. ...

774 I 228 G.B. ...

$7751123^{\circ}$ G.B. ...
TITLE AND JOURNAL. 


\begin{tabular}{|c|c|c|c|c|}
\hline $\begin{aligned} \text { ITEM } \\
\text { NO. }\end{aligned}$ & & $\begin{array}{l}\text { T.P. } \\
\text { T.P. }\end{array}$ & & TITLE AND JOURNAL. \\
\hline 7.79 & 10830 & U.S.A. & $\ldots$ & $\begin{array}{l}\text { Fundamental Celestial Navigation. (E. B. Collins, } \\
\text { Sci. Am., Vol. 168, No. 2, Feb., 1943, pp. 66-67.) }\end{array}$ \\
\hline 780 & $1086 \mathrm{i}$ & U.S.A. & $\ldots$ & $\begin{array}{l}\text { Astral Navigation for the Aerial Navigators. (Sci. } \\
\text { Am., Vol. I68, No. 4, April, 1943, pp. I64-165.) }\end{array}$ \\
\hline 781 & 10865 & U.S.A. & $\ldots$ & $\begin{array}{l}\text { New Lightning Shield. (Sci. Am., Vol. 168, No. 4, } \\
\text { April, 1943, p. r74.) }\end{array}$ \\
\hline 782 & 11070 & U.S.A. & $\ldots$ & $\begin{array}{l}\text { Effects of Solar Activity on the Ionosphere and } \\
\text { Radio Communications. (H. W. Wells, Procs., } \\
\text { I.R.E., Vol. 3r, No. 4, April, 1943, pp. 147-157.) }\end{array}$ \\
\hline 83 & I 1225 & G.B. & $\ldots$ & of Structures \\
\hline & & & & $\begin{array}{l}\text { (Nature, Vol. I5 I, No. 3,840, 5/ } \\
638 \text {-639.) }\end{array}$ \\
\hline
\end{tabular}

\section{PHYSIOLOGY AND AVIATION MEDICINE. (Parachute Baling Out, High Altitude Effects, etc.).}

$784 \quad 10625$ G.B. ... ... Functioning of the Human and Mcchanical System Under Simulated Flight Conditions. (Flight, Vol. 43, No. $1,795,20 / 5 / 43$, pp. 528-53 ${ }^{\text {r.) }}$

785 Iпा6 Germany ... The Effect of Extremely Rapid Reduction in Atmospheric Pressure on the Mammalian Organism (Abstract Available). (R. Kilches, Luftfahrtmedizin, Vol. 7 , No. I, I942, pp. 35-45.)

786 IIII7 Germany ... The Limits of Circulatory Adjustment in Acute Anoxcemia Experiment (Abstract Available). (H. Loeschcke, Luftfahrtmedizin, Vol. 7, No. I, 1942, pp. I-8.)

787 III18 Germany ... Compensated Anaglyphs to Koch's Visual Capacity Testing Apparatus. (Feulgen, Luftfahrtmedizin, Vol. 7, No. I, 1942, p. 46.)

788 IIII9 Germany ... The "Reduction Time" as an Index for Oxygen Supply of the Tissues. (Werz and Reiter, Luftfahrtmedizin, Vol. 7, No. I, 1942, p. 47.)

789 гाг Germany ... The Behaviour of Muscle Tone in Acute Anoxamia (Abstract Available). (Schnell, Luftfahrtmedizin, Vol. 7, No. 1, 1942, p. 68.)

790 I1 21 . Germany ... Survival Time After Very Sudden Drop in Pressure at Extremely High Altitudes. (Loutz, Luftfahrtmedizin, Vol. 7, No. I, 1942, pp. 84-97.)

791 III22 Germany ... Intestinal Movements Under the Influence of Anoxamia (Abstract Available). (G. A. Weltz and R. v. Werg, Luftfahrtmedizin, Vol. 7 , No. I, 1942, pp. 98-I I7.)

792 II123 Germany ... Suggestions for Defining the Disturbance Thresholds and Phases Through Oxygen Deficiency. (Diringshofen, Luftfahrtmedizin, Vol. 6, No. I-4, 23/4/42, pp. I 49-15I.)

793 III24 Germany ... The Action of Aerodynamic Forces on Circulation of Personnel Sitting in Aircraft. (Diringshofen, Luftfahrtmedizin, Vol. 6, No. I-4, 23/4/42, pp. I 52-165.)

794 I1125 Germany ... The Action of Doses of Sugar on the Resistance to Anoxamia and Acapnia at Great Altitudes. (Polonowski, Luftfahrtmedizin, Vol. 6, No. I-4, 23/4/42, p. 27o.) 
ITEM R.T.P.

No. REF.

795 III26 Germany

$796 \quad 11127$ Germany

$797 \quad$ I I 28 Germany

798 I I I 29 Germany

799 I I I $3^{\circ}$ Germany

$800 \quad 1113$ I Germany

8oI I1132 Germany

80211133 Germany

803 I I 34 Germany

804 I I I 37 Germany

805 I I 38 German

806 II 39 Germany

MATHEMATICS AND ASTRO-PHYSICS.

80710720 U.S.A. $\quad \ldots$ Characteristics of Centrally Supported Journal Bearings (Mathematical Solution of Reynolds Equation). (E. O. Waters, Trans. A.S.M.E., Vol. 64, No. 7, Oct., 1942, pp. 7 I I-719.)

$808 \quad 1081_{5}$ G.B. ... ... The Evaluation of the Complex Roots of Algebraic Equation. (A. F. Cornock and S. M. Hughes, Phil: Mag., Vol. 34, No. 232, May, 1943, pp. 3I4-320.)

809 I0839 Switzerland ... The Damping of Control Systems Obeying Equations of any Order. (A. Luthi, Escher Wyss, No. I5-16, 1942-1943, pp. 90-95.)

810 10840 Switzerland ... Simple Method for Calculating Critical Pressure Ratios for a Series of Stages (with Application to Stodola's Steam Cone Diagram). (H. Bollier, Escher Wyss, No. I5-16, I942-1943, pp. 96-100.) 
ITEM R.T.P.

No. REF.

811 II216 G.B. ... ... Origin of Cosmic Rays. (R. A. Millikan, Vol. I5I,

No. $3,841,12 / 6 / 43$, pp. 663-664.)

$812 \quad 11567$ U.S.A. $\quad$.. General Equation for the Analysis of Elliptic Rings. (D. O. Domasch, J. Aeron. Sci., Vol. 10, No. 4, April, 1943, pp. 119-1 26.)

813 II573 Germany ... Applications of the Principle of Parallelisms (Differential Geometry) to the Theory of Thin Shells. (F. Reutter, Z.A.M.M., Vol. 22, No. 2, April, 1942, pp. 87-98.) 